\title{
WATER-RESOURCES ACTIVITIES OF THE \\ U.S. GEOLOGICAL SURVEY IN ILLINOIS, 1993
}

Compiled by G.O. Balding

\section{U.S. GEOLOGICAL SURVEY}

Open-File Report 94-493 


\title{
U.S. DEPARTMENT OF THE INTERIOR BRUCE BABBITT, Secretary
}

\author{
U.S. GEOLOGICAL SURVEY \\ Gordon P. Eaton, Director
}

For additional information write to:

\section{District Chief}

U.S. Geological Survey

102 E. Main St., 4th Floor

Urbana, IL 61801
Copies of this report can be purchased from:

U.S. Geological Survey-ESIC

Open-File Reports Section

Box 25286, MS 517

Denver Federal Center

Denver, CO 80225-0046 


\section{CONTENTS}

Page

Origin and mission of the U.S. Geological Survey ..................................................................

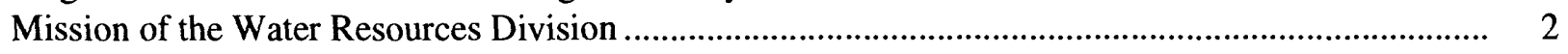

Illinois District organization ................................................................................................... 5

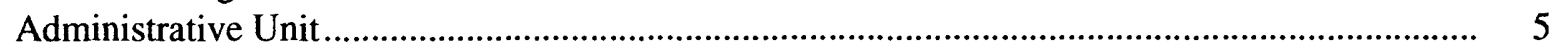

Publications and Data-Management Unit...................................................................... 5

National Water-Quality Assessment Unit ........................................................................... 5

Investigations Section................................................................................................. 5

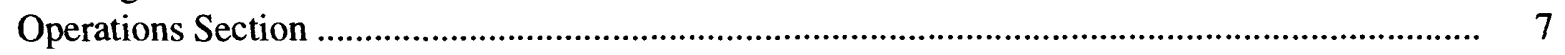

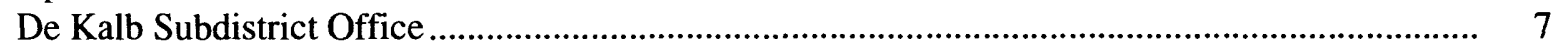

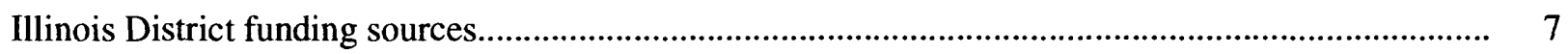

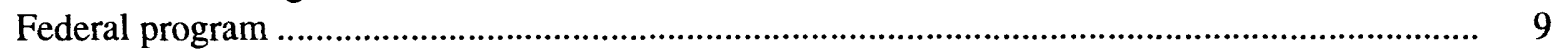

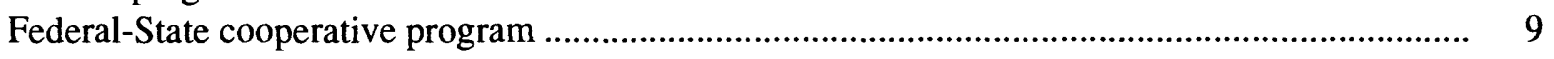

Other Federal agencies program........................................................................................ 9

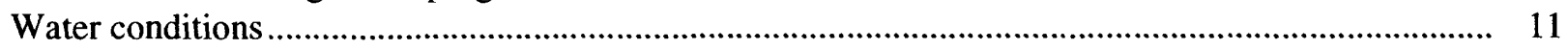

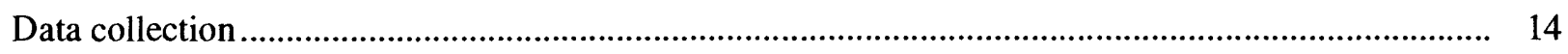

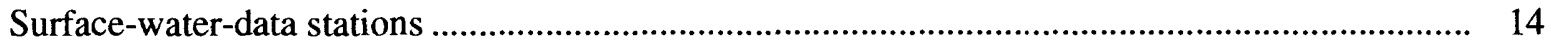

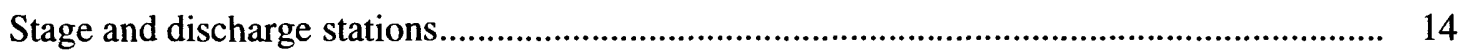

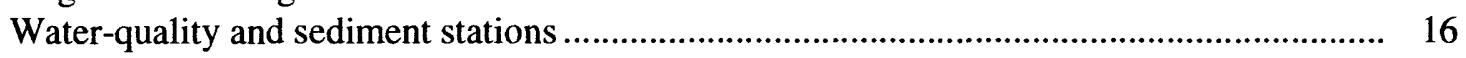

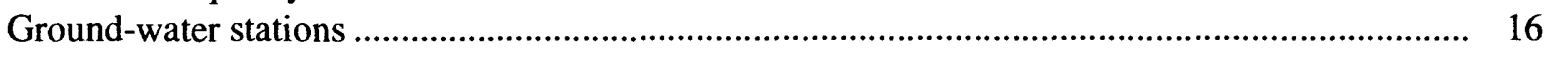

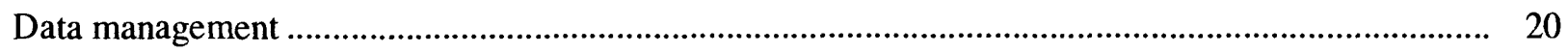

National Water Data Storage and Retrieval System ............................................................. 20

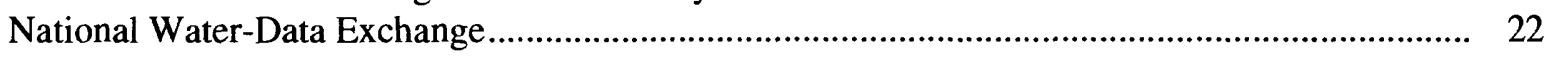

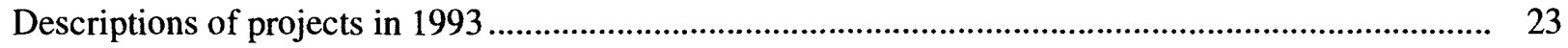

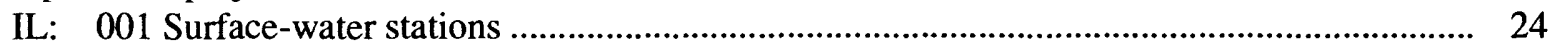

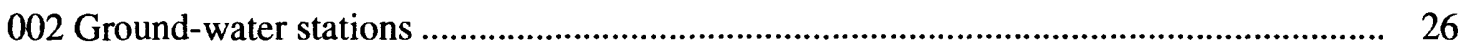

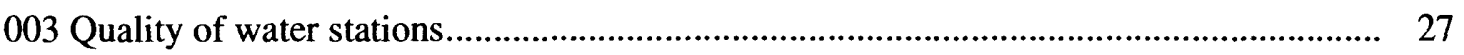

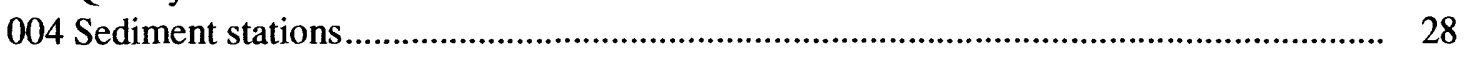

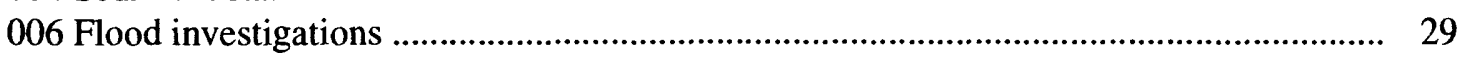

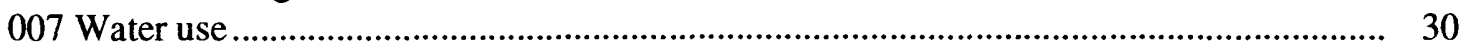

075 Upper Illinois River Basin water-quality assessment................................................. 32

080 USGS/USEPA interagency agreement projects ...................................................... 35

083 Rainfall-runoff relations in three small watersheds in Du Page County ....................... 37

086 A statistical and graphical description of Illinois ground-water quality ....................... 38

089 Rainfall-runoff relations in eight watersheds in Lake County, Illinois ......................... 39

093 Use of co-registered SLAR and TM imagery to classify and map land cover in northeastern Illinois ........................................................................................ 40

096 Hydrogeology and contaminant assessment in the southeastern Chicago area............... 41

097 Sedimentation of the Kankakee River ................................................................ 42

098 Transport and fate of volatile organic compounds during landfill-gas migration through the subsurface environment................................................................... 43

099 Hydraulic model verification and documentation for unsteady flow ........................... 44

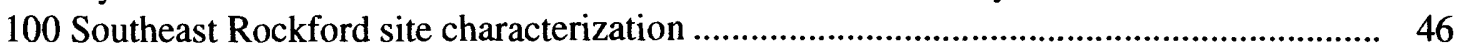

101 Crab Orchard oversight activities........................................................................... 47 


\section{CONTENTS}

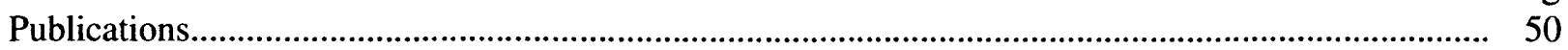

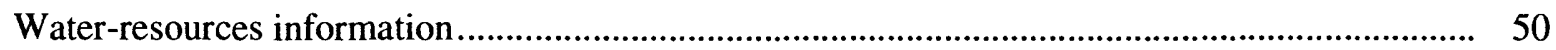

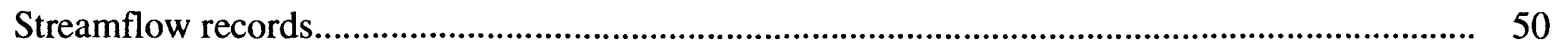

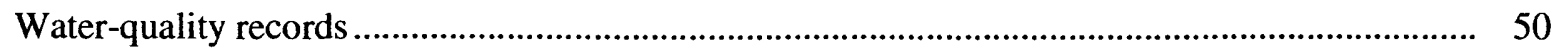

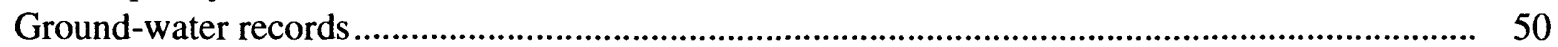

Publications pertinent to Illinois ................................................................................................. 50

Professional Papers............................................................................................................. 50

Water-Supply Papers ............................................................................................................ 51

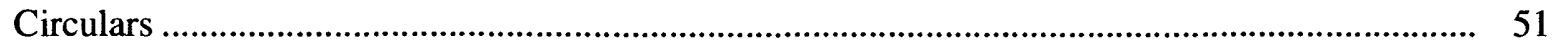

Hydrologic Investigations Atlases...................................................................................... 52

Hydrologic-Unit Maps ....................................................................................................... 53

Water-Resources Investigations Reports (WRI or WRIR) ………………….............................. 54

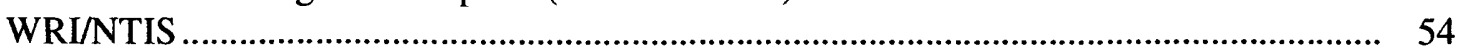

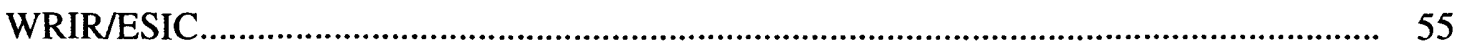

Open-File Reports (Earth Science Information Center)................................................................ 57

Water-Resources Investigations Open-File Reports …………................................................ 58

Miscellaneous reports.......................................................................................................... 59

Water-Data Reports ..................................................................................................... 59

Conference papers and abstracts and journal articles.................................................................. 59

Where to obtain additional information on U.S. Geological Survey programs in Illinois ...................... 63

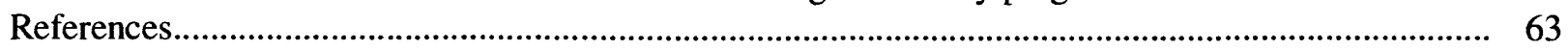

\section{Illustrations}

Figures 1-3. Charts showing:

1. U.S. Geological Survey organization.............................................................. 3

2. Water Resources Division organization.............................................................. 4

3. Illinois District organization and office addresses ................................................ 6

4-6. Maps showing:

4. Subdistrict and field headquarters areas of responsibility................................... 8

5. Average annual precipitation in Illinois, 1961-90............................................. 12

6. Index streamflow-gaging stations in Illinois..................................................... 13

7. Graph showing number of continuous-record streamflow-gaging stations operated by the Illinois District, U.S. Geological Survey, 1940-93 ......................................... 15

8-10. Maps showing:

8. Discharge and stage stations operated by the Illinois District in (a) Illinois except northeastern Illinois and (b) northeastern Illinois, $1993 \ldots \ldots \ldots \ldots \ldots \ldots \ldots . . .17$

9. Water-quality and sediment stations operated by the Illinois District, 1993 ...... 19

10. Ground-water stations operated by the Illinois District, by county, $1993 \ldots \ldots . . .21$ 


\section{CONTENTS}

Page

\section{Tables}

Table 1. Agencies supporting water-resources activities in Illinois during fiscal year 1993

2. Surface-water stations operated by the Illinois District for which data are published

3. Discontinued surface-water-discharge or stage-only stations operated by the Illinois District for which data were published.

4. Discontinued surface-water-quality and sediment stations operated by the Illinois District for which data were published

5. Ground-water stations in Illinois, by county, for which data are published by the Illinois District. 


\title{
WATER-RESOURCES ACTIVITIES OF THE U.S. GEOLOGICAL SURVEY IN ILLINOIS, 1993
}

\author{
Compiled by G.O. Balding
}

\section{ORIGIN AND MISSION OF THE U.S. GEOLOGICAL SURVEY}

The U.S. Geological Survey (USGS) was established by an Act of Congress on March 3, 1879, to provide a permanent Federal agency to conduct the systematic and scientific classification of the public lands, and examination of the geological structure, mineral resources, and products of the national domain.

Since 1879, the research and fact-finding role of the USGS has grown and has been modified to meet the changing needs of the Nation. The USGS, however, has remained an impartial scientific and technical agency without developmental or regulatory responsibilities. Today's programs serve a diversity of needs and users. The current mission of the USGS is to provide geologic, topographic, and hydrologic information that contributes to the wise management of the Nation's natural resources and that promotes the safety and well-being of the public. This information is provided to the public in many forms including reports, maps, and data bases that provide descriptions and analyses of the water, energy, and mineral resources, the land surface, the underlying geologic structure, and the dynamic processes of the Earth. To accomplish its mission, the USGS:

- Performs and sponsors research in geology, hydrology, mapping, and related sciences.

- Produces and updates geographic, cartographic, and remotely sensed information in graphic and digital forms.

- Describes the onshore and offshore geologic framework and develops an understanding of its formation and evolution.

- Assesses energy and mineral resources, determines their origin and manner of occurrence, and develops techniques for their discovery.

- Collects and analyzes data on the quantity and quality of surface water and ground water, on water use, and on quality of precipitation.

- Assesses water resources and develops an understanding of the impact of human activities and natural phenomena on hydrologic systems.

- Evaluates hazards associated with earthquakes, volcanoes, floods, droughts, toxic materials, landslides, subsidence, and other ground failures, and develops methods for hazards prediction.

- Participates in the exploration of space and prepares geologic and other maps of the planets and their satellites.

- Publishes reports and maps, establishes and maintains earth-science data bases, and disseminates earthscience data and information.

- Provides scientific and technical assistance for the effective use of earth-science techniques, products, and information.

- Coordinates topographic, geologic, and land-use mapping, digital cartography, and water-data activities. 
- Develops new technologies for the collection, coordination, and interpretation of earth-science data.

- Provides scientific support and technical advice for legislative, regulatory, and management decisions.

- Cooperates with other Federal, State, and local agencies, and with academia and industry.

As the Nation's largest earth-science research agency, the USGS maintains a long tradition of providing accurate and impartial information to all, which underscores its continued dedication to Earth Science in the Public Service.

\section{MISSION OF THE WATER RESOURCES DIVISION}

The USGS has the principal responsibility within the Federal Government to provide the hydrologic information and understanding needed by others to achieve the best use and management of the Nation's water resources. To accomplish this mission, the Water Resources Division in cooperation with other Federal, State, and local agencies:

- Systematically collects data needed for the continuing determination and evaluation of the quantity, quality, and use of the Nation's water resources.

- Performs analytical and interpretive water-resources appraisals to describe the presence, availability, and physical, chemical, and biological characteristics of surface and ground water and their interrelation.

- Performs supportive basic and problem-oriented research in hydraulics, hydrology, and related fields of science and engineering to improve the basis for field investigations and measurement techniques and to understand hydrologic systems sufficiently well to predict quantitatively their response to stress, either natural or manmade.

- Disseminates water data and the results of investigations and research through reports, maps, computerized information services, and other forms of public release.

- Coordinates the activities of all Federal agencies in the acquisition of certain water data.

- Provides scientific and technical assistance in hydrologic fields to State, local, and other Federal agencies, to licensees of the Federal Energy Regulatory Commission, and, on behalf of the U.S. Department of State, to international agencies.

- Acquires, develops, and disseminates information on water-related natural hazards such as droughts, floods, landslides, land subsidence, mudflows, and volcanoes.

- Administers the provisions of the Water Resources Research Act of 1984, which includes the State Water Resources Research Institutes and the Research Grants program.

- Supports the provisions of the National Environmental Policy Act of 1969 and manages USGS conduct of natural-resources surveys in response to the Comprehensive Environmental Response, Compensation, and Liability Act (Superfund Act) of 1980.

The Water Resources Division is one of three program Divisions and two support Divisions within the USGS (fig. 1). The headquarters of the Water Resources Division is located at the USGS's National Center in Reston, Va., and consists of the Office of the Chief Hydrologist, the Offices of the Assistant Chief Hydrologists for Operations, Program Coordination and Technical Support, Research and External Coordination, Scientific Information Management, and Water Assessment and Data Coordination (fig. 2). 


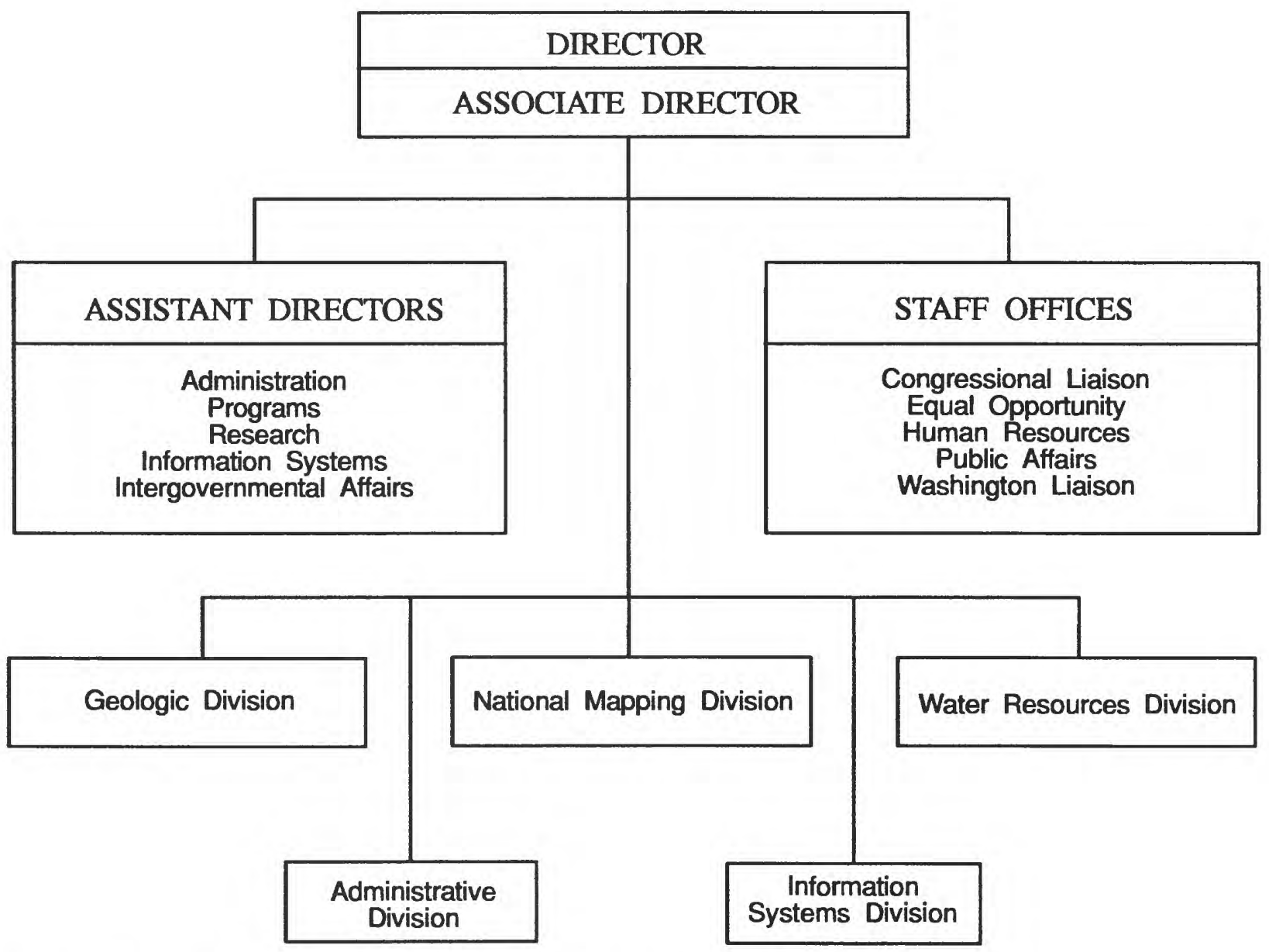

Figure 1. U.S. Geological Survey organization. Data from U.S. Geological Survey, 1992.

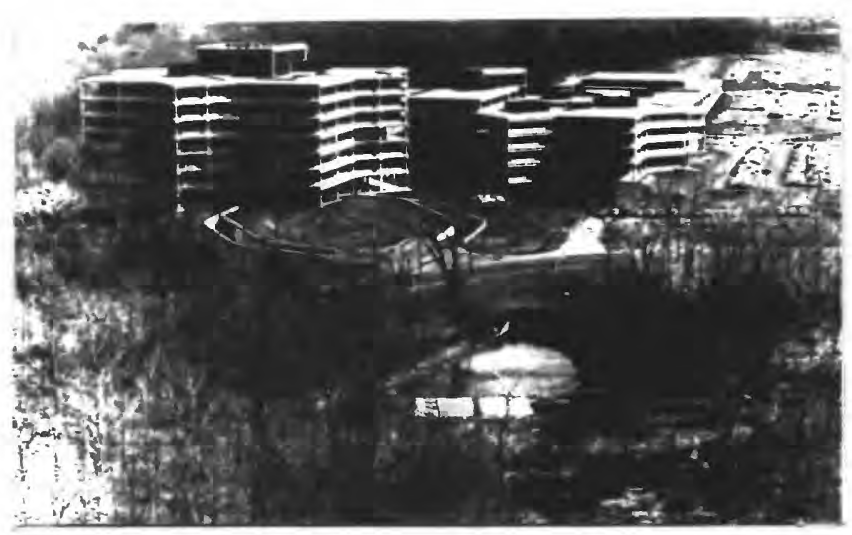

John Wesley Powell Federal Building, Reston, Virginia, National Center of the U.S. Geological Survey 


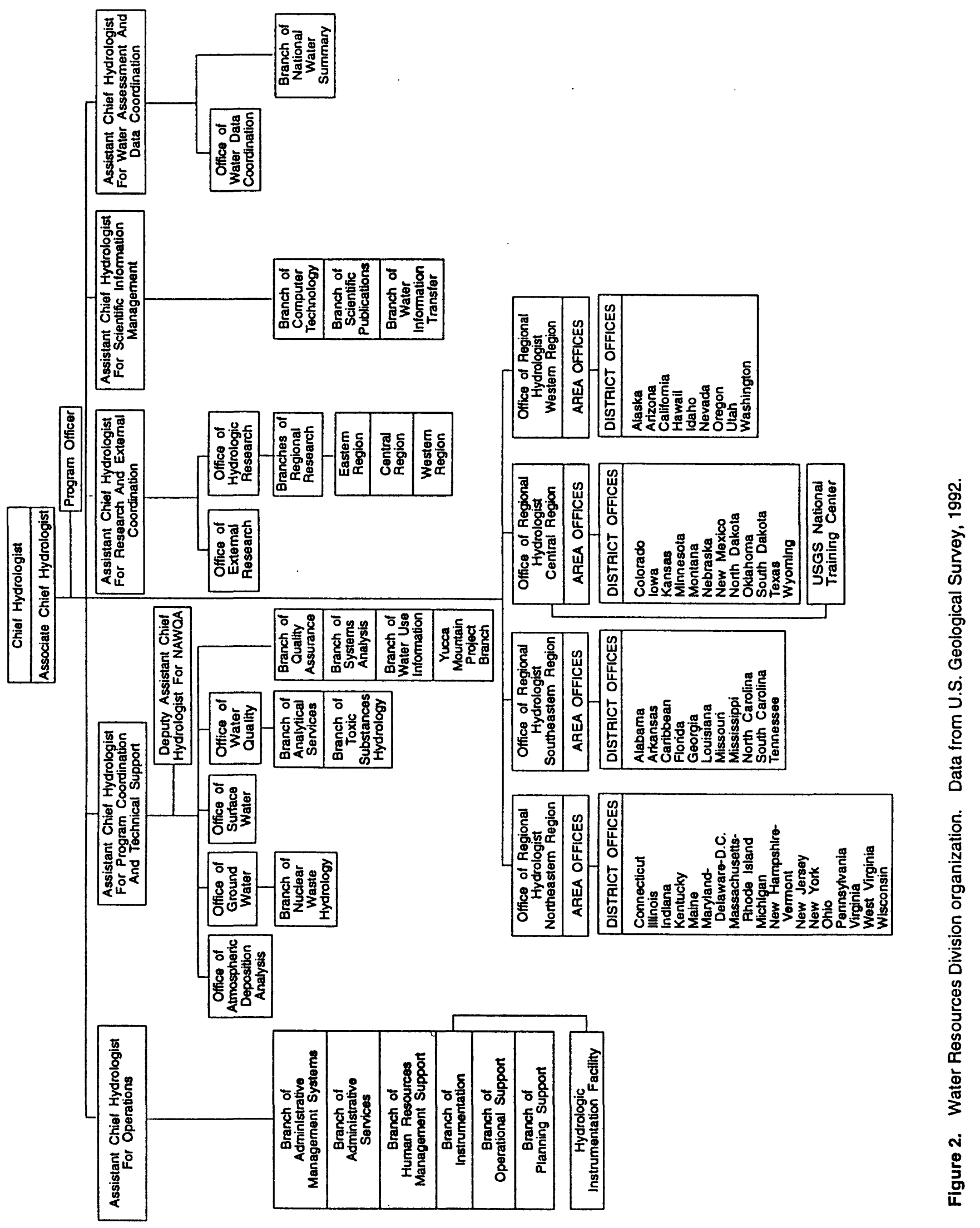




\section{ILLINOIS DISTRICT ORGANIZATION}

The Illinois District of the USGS, Water Resources Division, consists of two support units, a specialstudy unit, two operating sections, one Subdistrict Office, and two Field Headquarters (fig. 3). Personnel are based at the District Office in Urbana, the Subdistrict Office in De Kalb, and at Field Headquarters in Urbana and Mt. Vernon. The District operates with guidance from Regional and National offices in Reston, Va. Offices for research, training, equipment development, and laboratory services, located throughout the United States, provide technical assistance and advice to the District.

\section{Administrative Unit}

The Administrative Unit is responsible for the maintenance of and compliance with Federal acquisition regulations, Department of the Interior manuals, and USGS and Water Resources Division operating policies. The Unit provides support services in the areas of administrative management, budget formulation and execution, financial planning and accounting, personnel, procurement, space management, and general office procedures.

\section{Publications and Data-Management Unit}

The Publications and Data-Management Unit assembles reports for review, prepares camera-ready copy for publication, and maintains the District's computer system, data files, and library. The Unit provides data processing services, maintains a library of computer manuals and program catalogs, does computer programming, and assists hydrologists in program selection, application, and modification.

\section{National Water-Quality Assessment Unit}

The NAtional Water-Quality Assessment (NAWQA) Unit is responsible for carrying out the goals of the NAWQA program for the upper Illinois River Basin NAWQA project. The goals of the NAWQA program are to (1) describe water-quality conditions and trends and (2) identify, describe, and explain causative factors for the observed conditions and trends. The upper Illinois River Basin project is one of seven NAWQA pilot studies that will test, and modify as necessary, concepts and approaches in preparation for full implementation of the NAWQA program in the future.

\section{Investigations Section}

The Investigations Section conducts multi-discipline hydrologic investigations to determine the quantity and quality of surface and ground water and to define and evaluate the extent and availability of water resources of drainage basins, counties, and the State. The Section performs special hydrologic research studies on current water issues such as nuclearhydrology, sedimentation and erosion, urban hydrology, land-use mapping, rainfall-runoff modeling, hydraulic unsteady-flow modeling, ground-water quality, U.S. Environmental Protection Agency (USEPA) Superfund Site work, waste disposal, and stream quality. Special investigative techniques for water-resource evaluation include the use of test drilling, packer tests, tracers, surface and borehole geophysics, and ground-water and surface-water modeling of flow and solute movement. Personnel prepare and review reports of investigations for both scientific and lay audiences. 


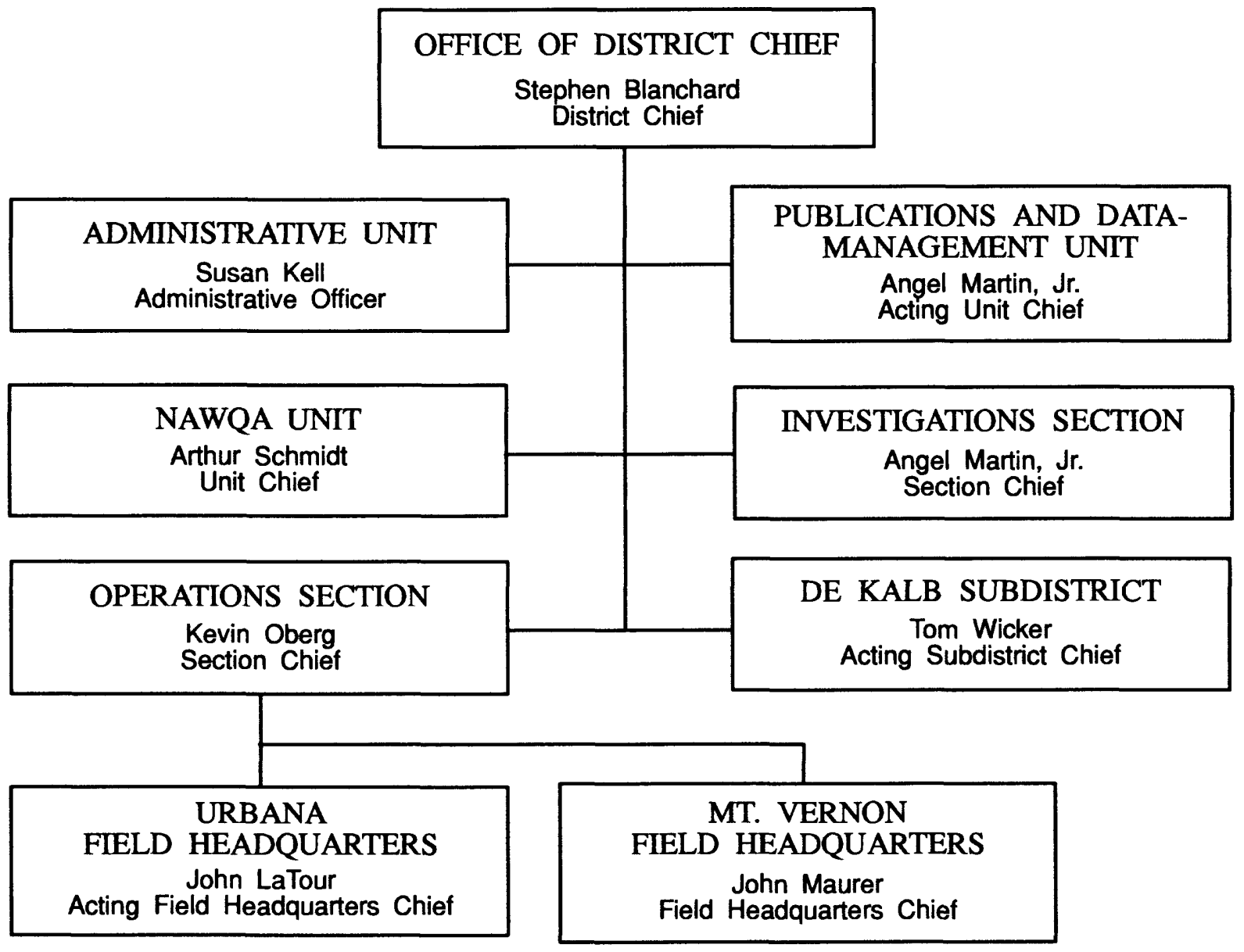

District Office

(217) $398-5353$

De Kalb Subdistrict Office

Urbana Field

Headquarters

Mt. Vernon Field

Headquarters
(815) 756-9207

(217) $398-5570$

(618) $242-4495$
U.S. Geological Survey

102 E. Main Street, 4th Floor Urbana, IL 61801

U.S. Geological Survey 1420 Sycamore Road

De Kalb, IL 60115

U.S. Geological Survey 102 E. Main Street, 4th Floor Urbana, IL 61801

U.S. Geological Survey Room 231, Federal Building 105 S. Sixth Street Mt. Vernon, IL 62864

Figure 3. Illinois District organization and office addresses. 


\section{Operations Section}

The Operations Section designs and implements a network of streamflow, water-quality-, and sediment-sampling sites based on data needs. The Section directs the installation and maintenance of equipment, data collection and analysis, and compilation of records for publication in the annual data report. It maintains the drainage-area and water-use map files and all associated hydrologic-data files. The Section provides assistance in the collection of water-resources data in support of projects, conducts special data-collection efforts as needed or requested including major floods, low-flow measurements, and indirect measurements. The Section conducts special projects related to water use and coordinates the water-use program. Field offices are responsible for data collection in their designated areas (fig. 4) and report to the Chief, Operations Section.

\section{De Kalb Subdistrict Office}

The De Kalb Subdistrict Office performs multi-discipline hydrologic investigations to determine the quantity and quality of surface and ground water and to define and evaluate the extent and availability of water resources of drainage basins and counties in the northern quarter of Illinois. The Subdistrict maintains a network of stream-gaging sites and directs the data collection, analysis, and compilation of records for publication in the annual data report.

\section{ILLINOIS DISTRICT FUNDING SOURCES}

Funds to support the work performed by the Illinois District, Water Resources Division, are derived from three principal sources-Federal Program, Federal-State Cooperative Program, and Other Federal Agencies Program. The activities funded are directed toward obtaining the information needed by managers and planners to achieve the best use and management of the water resources in Illinois and the Nation. Funding from all sources in fiscal year 1993 amounted to about $\$ 4,104,000$, which was distributed as follows:

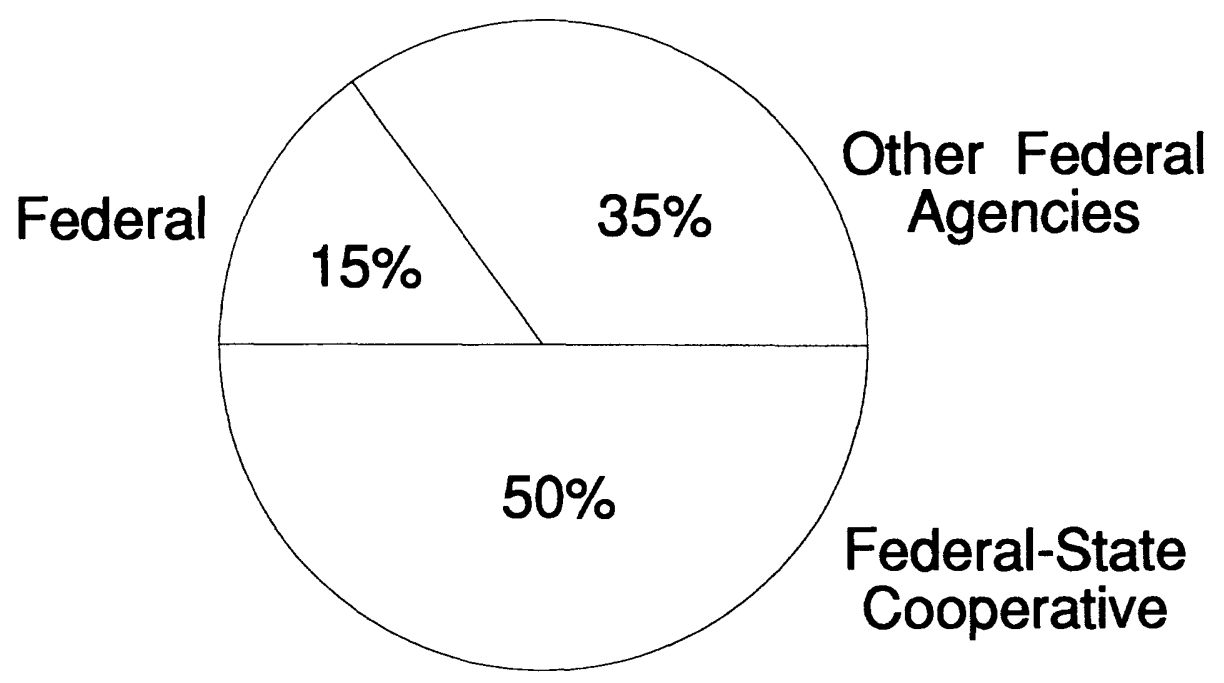




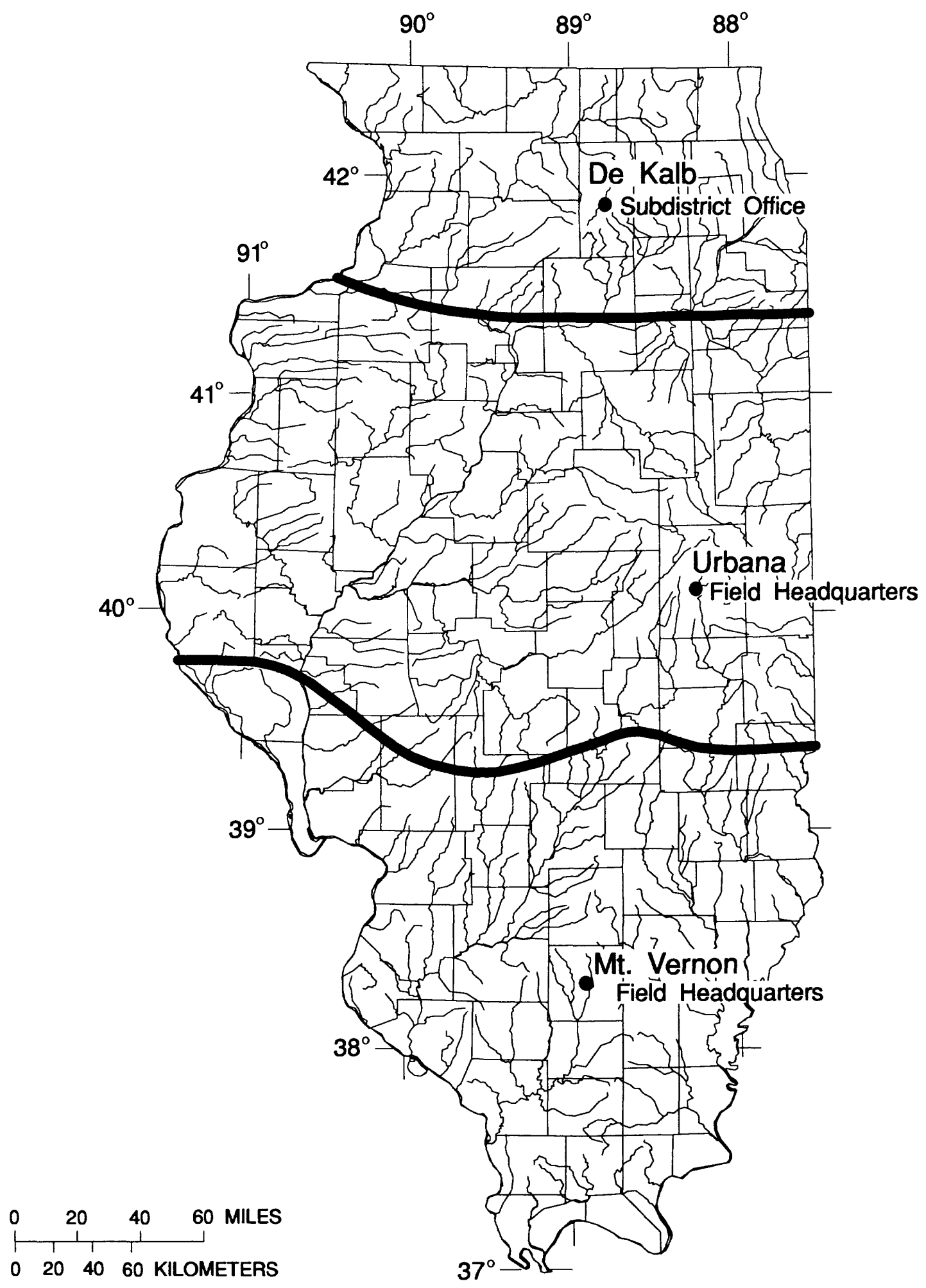

Figure 4. Subdistrict and field headquarters areas of responsibility. 
The diagram below shows the percentage of the activities for fiscal year 1993 in the two broad categories of hydrologic-data collection and water-resources investigations:

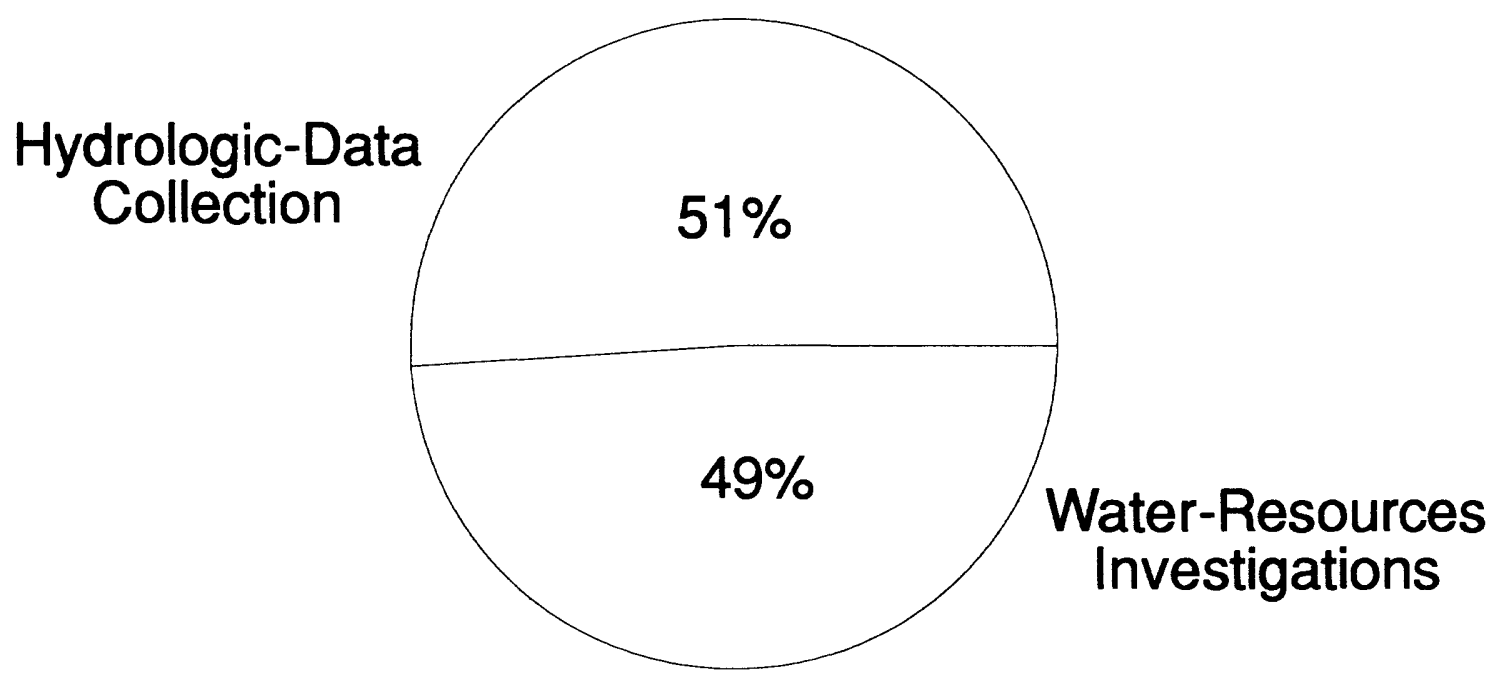

Federal Program

Funds for the Federal Program are appropriated by Congress and are specifically identified in the annual USGS budget. These funds are used to support research, data collection, high-priority topical programs, the coordination of all Federal programs related to collection of water data, and internal support services.

\section{Federal-State Cooperative Program}

Federal funds are appropriated by Congress for the Federal-State Cooperative Program and used to match those furnished by State and other local tax-supported agencies on a 50-50 basis (Gilbert and Mann, 1993). These funds are used for a variety of hydrologic-data-collection activities and water-resources investigations in which there are both national interests and State and local interests. Agencies supporting water-resources activities in Illinois during fiscal year 1993 are listed in table 1.

\section{Other Federal Agencies Program}

In this program, the funds are transferred to the USGS as reimbursement for work performed at the request of another Federal agency. These funds are used for a variety of hydrologic-data collection and water-resources investigations such as stream gaging, ground-water-quality assessments, and suspendedsediment monitoring in streams. 
Table 1. Agencies supporting water-resources activities in Illinois during fiscal year 1993

\title{
$\underline{\text { State Agencies }}$
}

\author{
Illinois Department of Transportation \\ Division of Water Resources \\ Illinois Environmental Protection Agency \\ Division of Water \\ Illinois Department of Energy and Natural Resources \\ State Water Survey \\ Illinois Department of Conservation \\ Wisconsin Department of Natural Resources
}

\section{Local Agencies}

Bloomington and Normal Sanitary District

Forest Preserve District of Cook County

Forest Preserve District of Du Page County

Du Page County, Department of Environmental Concerns,

Stormwater Management Division

Kane County Development Department

Kane County Forest Preserve Commission

Lake County Stormwater Management Commission

Vermilion County Conservation District

Winnebago County, Department of Public Works

The Metropolitan Water Reclamation District of Greater Chicago,

Division of Research and Development

Danville Sanitary District

City of De Kalb, Public Works Department

City of Decatur, Public Works Department

City of Springfield, Commission of Public Property

City of Monticello, City Services

Kankakee Soil and Water Conservation District

Boneyard Creek Commission

\section{Federal Agencies}

Department of the Army

Corps of Engineers

Rock Island District

St. Louis District

Louisville District

Chicago District

U.S. Environmental Protection Agency, Region V

Federal Emergency Management Agency

U.S. Fish and Wildlife Service 


\section{WATER CONDITIONS}

Illinois generally has adequate supplies of water suitable for most uses. The mean annual precipitation for the 1961-90 period is shown in figure 5. Water is available from several major rivers and lakes within or bordering Illinois and from ground-water sources. In the northern one-third of the State, most municipal water supplies (excluding the Chicago metropolitan area) are obtained from ground water, whereas, in the remainder of the State, municipal water supplies generally are obtained from surface-water sources. In the southern two-thirds of the State, however, potable ground water can be obtained locally from shallow alluvium-filled valleys that were eroded into the bedrock by ancestral streams.

The 1993 water year (October 1, 1992, to September 30, 1993) was climatically eventful. Annual average precipitation ranged from 109 percent $(48.41$ in.) of the 30-year (1961-90) normal in the southeastern part of the State to 156 percent $(58.42$ in.) of normal in the western part of the State. Statewide, average total precipitation was 139 percent (53.47 in.) of normal. Monthly precipitation ranged from a low of 0.84 in. ( 70 percent of normal) in the northwestern part of the State in February to a high of 9.94 in. (230 percent of normal) in the western part of the State in July.

The Great Flood (Disaster) of '93 in Illinois was devastating. Extensive property damage as a result of the flooding occurred along the Illinois side of the Mississippi River and along the lower reaches of the Illinois River. Several Illinois streams tributary to the Mississippi went into backwater conditions. During some periods in July and August, the Big Muddy River at Murphysboro (05599500) reversed flow

because of the high-water conditions in the Mississippi River. Backwater conditions in the Kaskaskia River were observed as far upstream as the gaging station at Carlyle (05593000) just below the dam at Carlyle Lake, 94 miles upstream from the Mississippi River.

Damage to agricultural lands and communities in Illinois from flooding was extensive. Five-hundred thousand acres were flooded resulting in $\$ 1.5$ billion in crop and property damage, 39,000 homes were damaged, 12,800 people were evacuated, 4 lives were lost, and 25 counties were declared federal disaster areas. At least 24 levees were breached or overtopped by the Mississippi and Illinois Rivers (Ryan, 1993, p. 371).

Annual mean discharges at all of the 144 continuous-record streamflow-gaging stations in Illinois, except for the Cache River at Forman (03612000), exceeded the annual mean discharge for their period of record. Annual mean discharges in the Illinois River Basin ranged from 123 percent of normal at Spring Brook at Forest Preserve near Warrenville (05540091) to 330 percent at Spoon River at Seville (05570000). Annual mean discharges for tributaries to the Mississippi River, upstream from the mouth of the Illinois River, ranged from 165 percent of normal at Sinsinawa River near Menominee (05414820) to 373 percent of normal (the largest deviation recorded statewide) at Mill Creek at Milan (05448000). Annual mean discharges for tributaries to the Mississippi, downstream from the mouth of the Illinois River, were less than 200 percent of normal. Tributaries to the Wabash River had annual mean discharges that ranged from 117 percent of normal at Bonpas Creek at Browns (03378000) to 268 percent of normal at Vermilion River near Danville (03339000).

Mean monthly discharge at the three long-term index streamflow-gaging stations (fig. 6) was in the normal-flow range (discharge between the 25th and 75th percentile of distribution of mean monthly discharges for the period of record) only during October and February at Pecatonica River at Freeport (05435500); October, December, February, and May at Sangamon River at Monticello (05572000); and October, December, February, March, May, and June at Skillet Fork at Wayne City (03380500). During all other months, mean monthly discharges at the index stations were in the excessive-flow range (discharge equal to or greater than the 75 th percentile). 


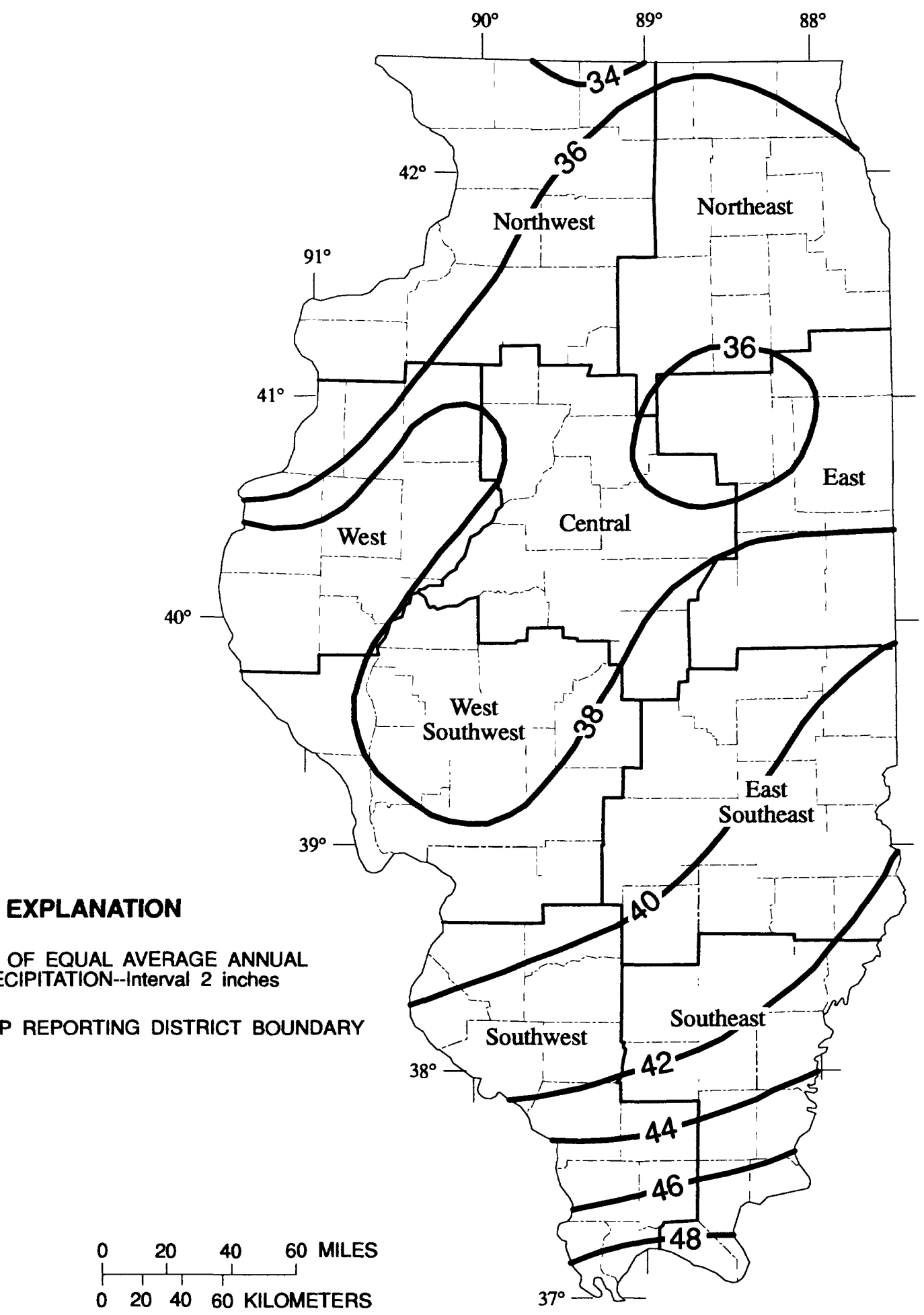

Figure 5. Average annual precipitation in Illinois, 1961-90. Data from Wendland and others, 1992. 


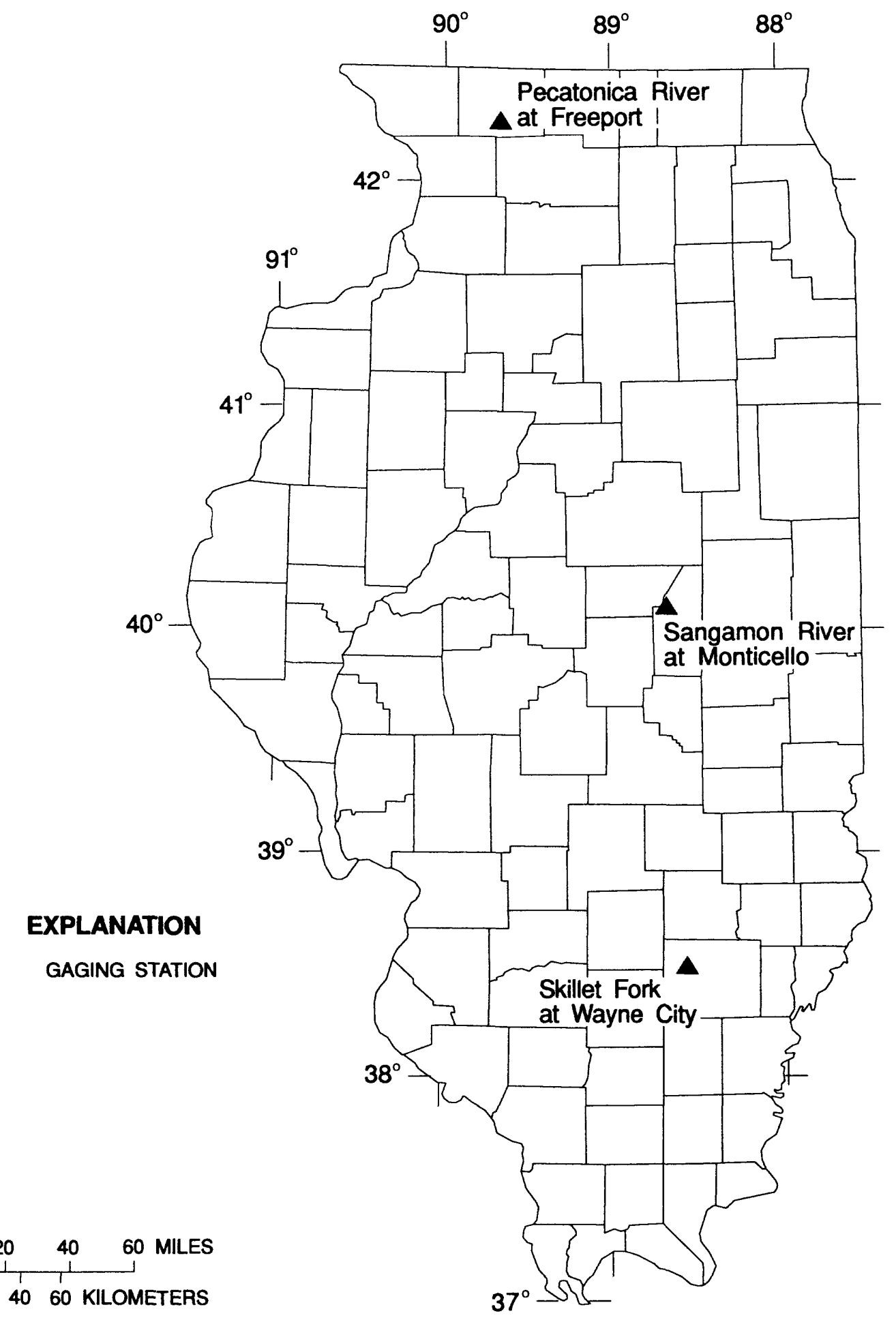

Figure 6. Index streamflow-gaging stations in Illinois. 
Peak discharges of record were set at some streamflow-gaging stations in Illinois during January, March, June, and July. June 1993 was the seventh wettest June since 1895 (Illinois State Water Survey, written commun., 1993); more severe weather was recorded during this month than all of the spring months combined. The 15 days of sustained rainfall during the latter part of June, and the abnormally high precipitation in the upper Midwest during the late spring and early summer, contributed to the widespread destruction from flooding along the Mississippi and Illinois Rivers.

\section{DATA COLLECTION}

The USGS Water Resources Division is the principal Federal agency responsible for providing hydrologic information required for the best utilization and management of the Nation's water resources. The activities of the Illinois District are structured to provide data and information required to meet these needs.

\section{Surface-Water-Data Stations}

Surface-water data are collected for general hydrologic purposes such as assessments of water resources, areal analyses, determination of long-term trends, research and special studies, or for management and operational purposes. The need for surface-water data in Illinois has varied over the years. In 1940, the USGS operated 46 continuous-record streamflow-gaging stations; by 1980, the streamflow-gaging-station network increased to 183. Currently (1993), the Illinois District of the USGS is operating 144 continuous-record streamflow-gaging stations (fig. 7).

\section{Stage and Discharge Stations}

Stage data are generally recorded every 15 minutes at each continuous-record stage-only and streamflow-gaging station; some stations are equipped with telemetry and transmit stage data on a near realtime basis to the District office where it is converted to discharge. In 1993, data on stage and discharge in Illinois were recorded and published by the Illinois District for the following numbers of stations:

\begin{tabular}{|c|c|}
\hline Station classification & $\begin{array}{l}\text { Number of } \\
\text { stations }\end{array}$ \\
\hline Stream stations & 163 \\
\hline 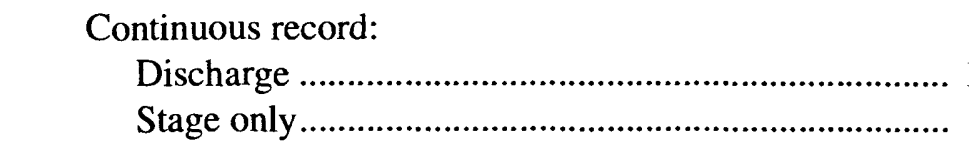 & $\begin{array}{r}144 \\
7\end{array}$ \\
\hline $\begin{array}{l}\text { Partial record: } \\
\text { Peak (maximum) flow only }\end{array}$ & 12 \\
\hline 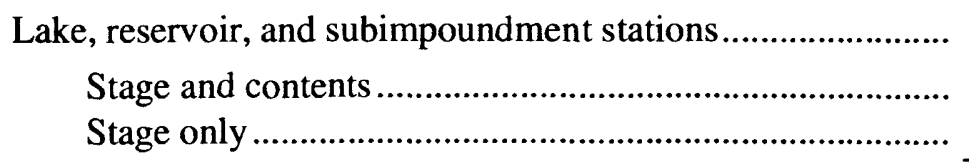 & $\begin{array}{l}3 \\
5\end{array}$ \\
\hline . & 171 \\
\hline
\end{tabular}




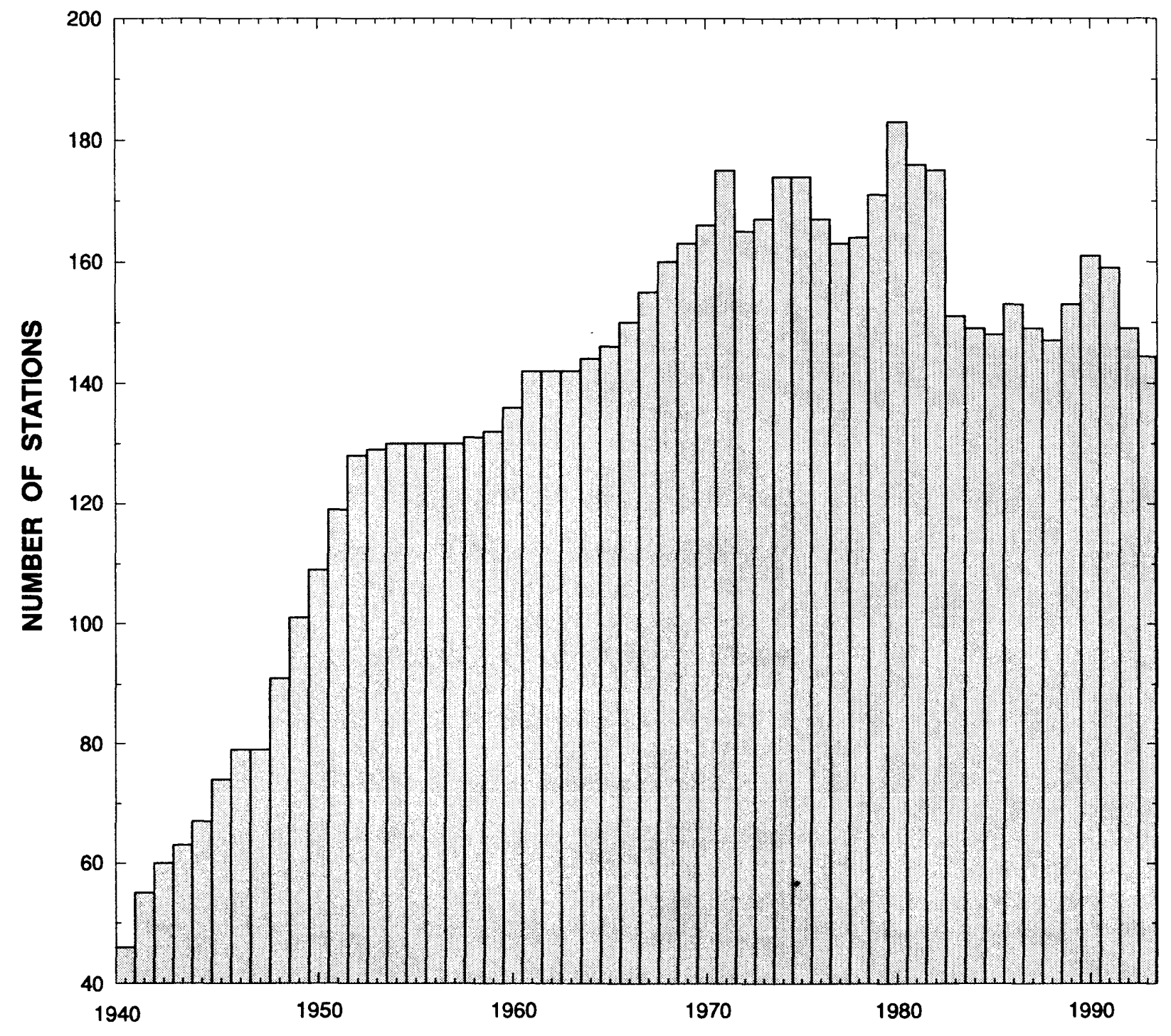

Figure 7. Number of continuous-record streamflow-gaging stations operated by the Illinois District, U.S. Geological Survey, 1940-93. 
Of the 144 continuous-record streamflow-gaging stations, 138 are part of the Illinois District surfacewater network and the other 6 are used for special projects. The locations of these stations and stage-only stations are shown in figure 8 , and the types of data collected at each station are shown in table 2 (at end of report); discontinued surface-water-discharge or stage-only stations in Illinois are listed in table 3 (at end of report).

\section{Water-Quality and Sediment Stations}

Water-quality samples were collected monthly, quarterly, or bimonthly depending upon the particular station. The water-quality constituents of interest included physical parameters, nutrients, trace metals, suspended sediment, and organics. Data were collected from eight water-quality sampling stations operated by the Illinois District during fiscal year 1993. Station locations are shown in figure 9 and are listed in table 2 (at end of report). Of the eight stations, six stations are operated as part of the USGS's NAtional Stream Quality Accounting Network (NASQAN) program; the remaining two stations are a part of the USGS's Federal program and the Federal-State cooperative program.

Daily or near-daily suspended-sediment samples were collected from, and daily suspended-sedimentdischarge records were computed for 11 stations; the station locations are shown in figure 9 and listed in table 2 (at end of report). Of the 11 stations, 5 are operated as part of the sediment network and the remaining 6 are project stations, two of which are located in Indiana.

The discontinued surface-water-quality and suspended-sediment stations operated by the Illinois District are listed in table 4 (at end of report). The various types of water-quality and suspended-sediment data were collected and published by the Illinois District for the following numbers of surface-water stations:

Data classification $\quad \begin{gathered}\text { Number of } \\ \text { stations }\end{gathered}$

Physical data:

Water temperature ................................ 8

Specific conductance ........................... 8

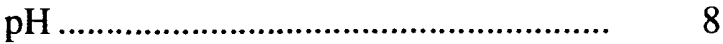

Dissolved oxygen ................................. 7

Sediment data (daily)................................... 11

Chemical data:

Inorganic constituents............................ 8

Organic constituents ............................. 8

Microbiological data................................... 7

\section{Ground-Water Stations}

Water-level measurements in wells, discharges of springs and wells, and ground-water-quality analyses are used in assessing ground-water conditions and trends; hydrologic data, however, must be integrated with other observations and studies of ground-water systems to understand ground-water conditions and trends. In Illinois, the USGS measures water levels in 12 observation wells. Four wells, 
A

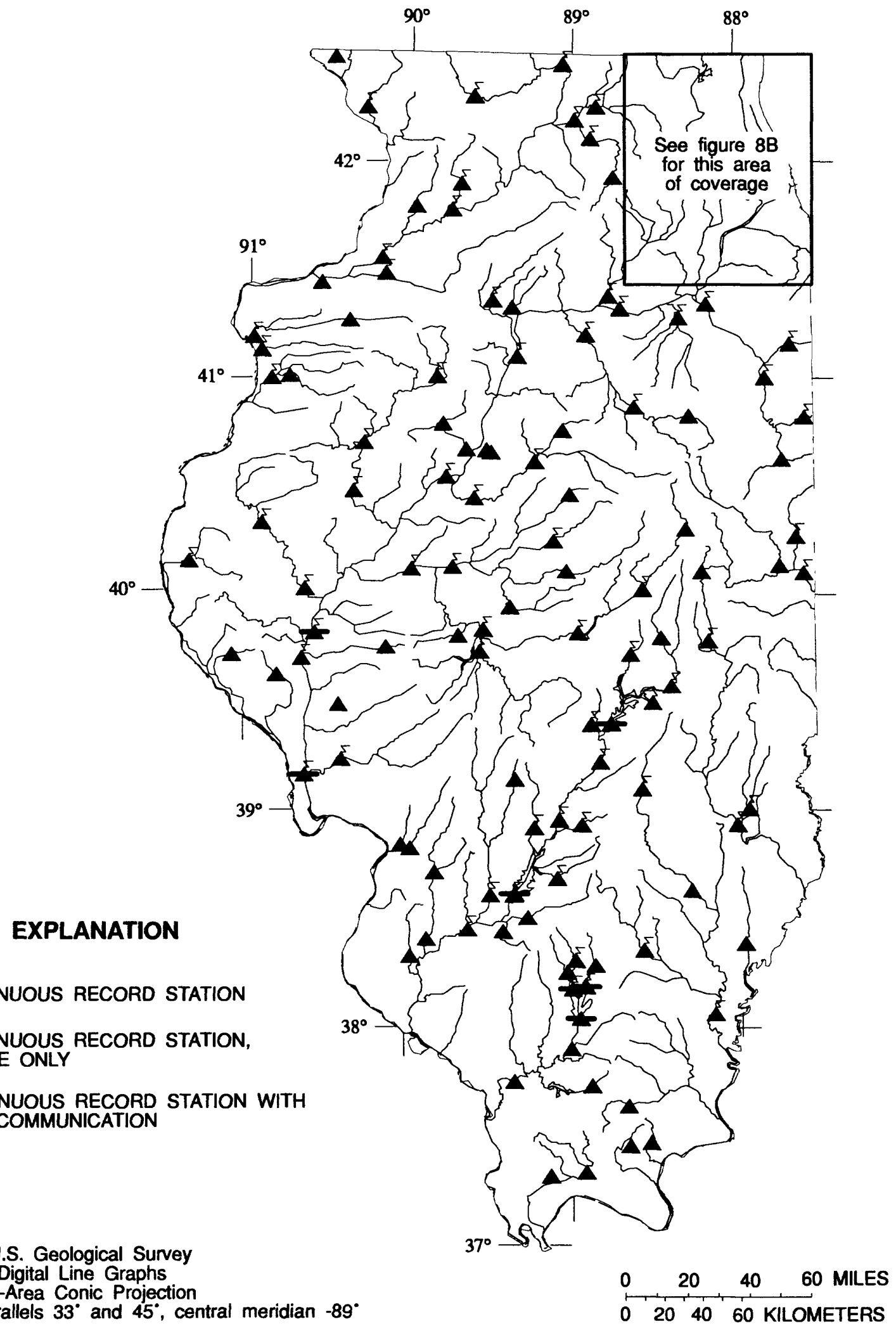

Base from U.S. Geological Survey 1:2,000,000 Digital Line Graphs Albers Equal-Area Conic Projection

Standard parallels $33^{\circ}$ and $45^{\circ}$, central meridian $-89^{\circ}$

\begin{tabular}{llllll}
0 & 20 & 40 & 60 & MILES \\
\cline { 2 - 2 } & 20 & 40 & 60 KILOMETERS
\end{tabular}

Figure 8. Discharge and stage stations operated by the Illinois District in (a) Illinois except northeastern Illinois and (b) northeastem Illinois, 1993. 
B

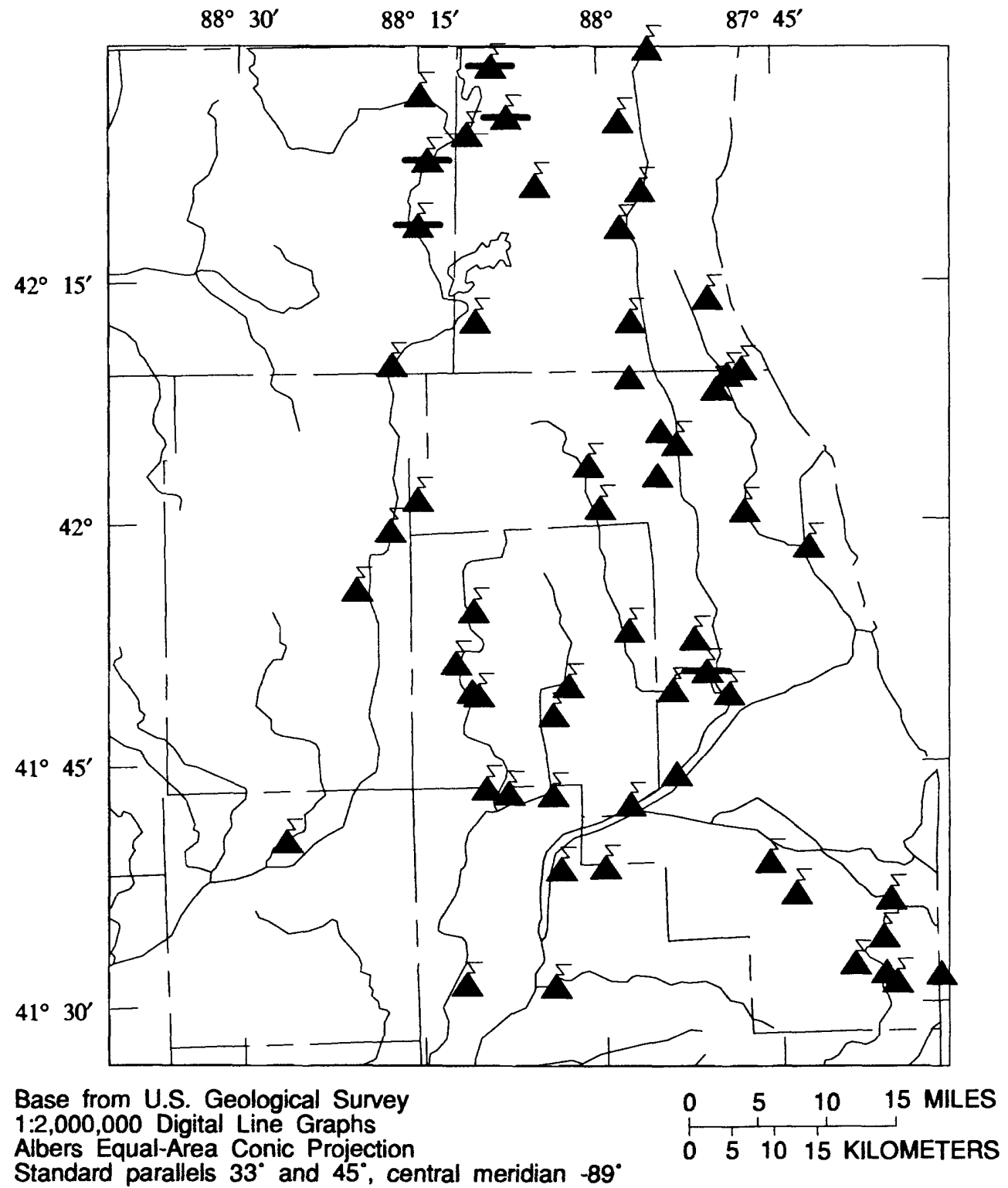

\section{EXPLANATION}

- CONTINUOUS RECORd Station

* continuous Record station, STAGE ONLY

$\Sigma$ CONTINUOUS RECORD STATION WITH

Figure 8. Continued. 


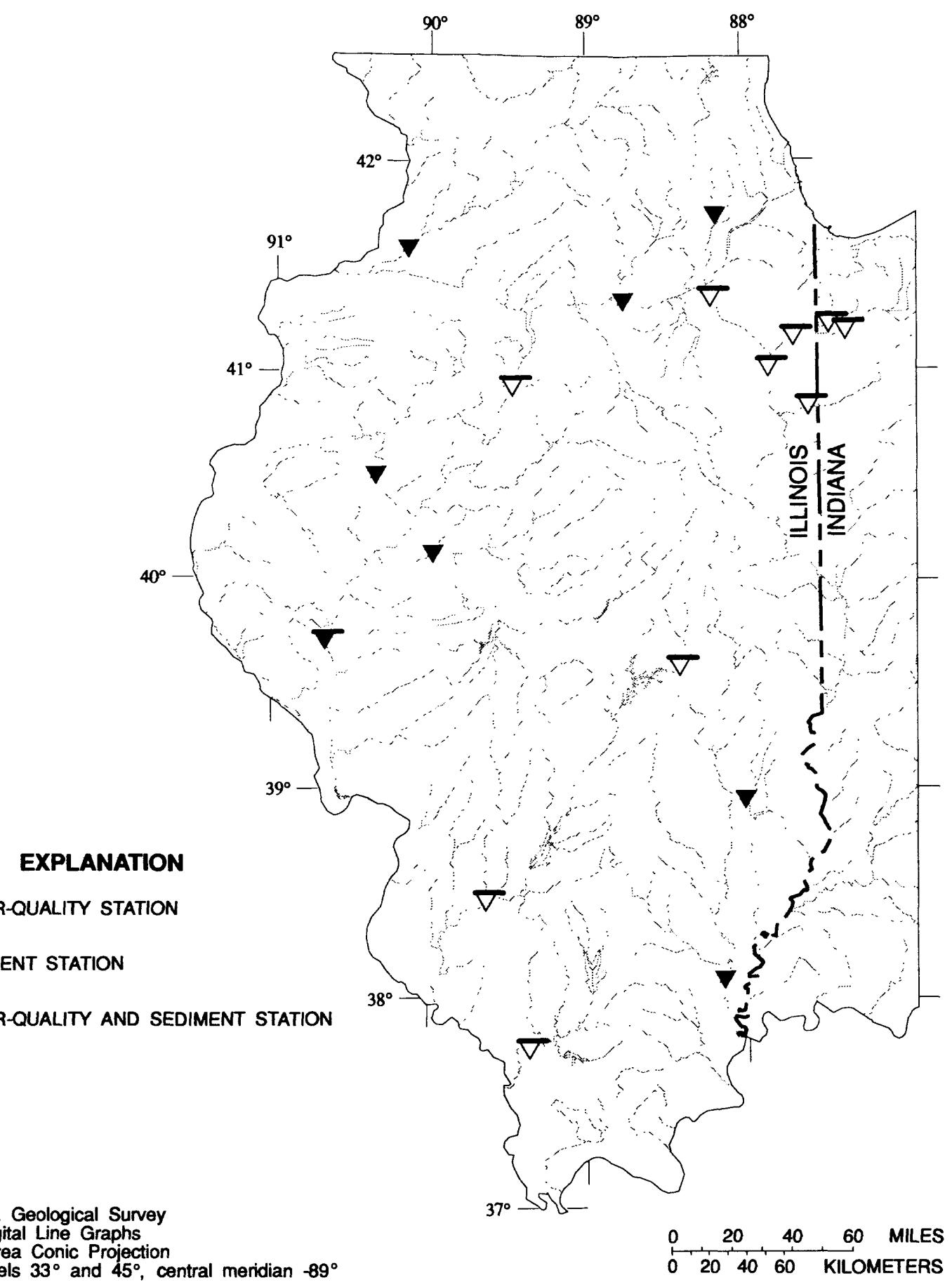

Base from U.S. Geologica

1:1,000,000 Digital Line Graphs

Standard parallels $33^{\circ}$ and $45^{\circ}$, central meridian $-89^{\circ}$

$\begin{array}{llllll}0 & 20 & 40 & 60 & \text { MILES } \\ 0 & 20 & 40 & 60 & \text { KILOMETERS }\end{array}$

Figure 9. Water-quality and sediment stations operated by the Illinois District, 1993. 
three of which are piezometers, are at the same location but at different depths. Water samples are periodically collected for water-quality analysis from 2 of the 12 observation wells. Water samples from 50 public-supply wells in the State are collected and analyzed as part of an ongoing water-quality study in cooperation with the IEPA; water samples are collected annually from these wells. The types of data collected for observation and project wells are as follows:

\begin{tabular}{|c|c|}
\hline Data type & $\begin{array}{c}\text { Number of } \\
\text { wells }\end{array}$ \\
\hline Water levels & 12 \\
\hline \multicolumn{2}{|l|}{ Physical data: } \\
\hline 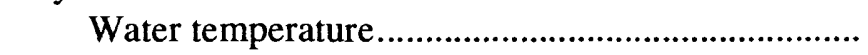 & 56 \\
\hline Specific conductance & 56 \\
\hline $\mathrm{pH}$ & 56 \\
\hline \multicolumn{2}{|l|}{ Chemical data: } \\
\hline 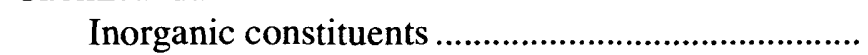 & 56 \\
\hline 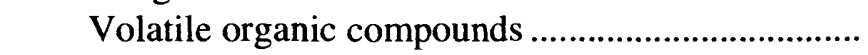 & 51 \\
\hline 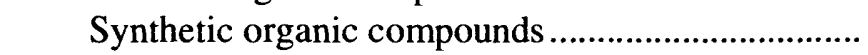 & 51 \\
\hline
\end{tabular}

The ground-water stations and types of data collected at each station are listed in table 5 (at end of report). The number of stations, by county, are shown in figure 10.

\section{DATA MANAGEMENT}

The USGS Water Resources Division manages data from its own activities and from the activities of other water-oriented agencies. The data are stored in the National Water Data Storage and Retrieval System. Data site information is available from the National Water-Data Exchange.

\section{National Water Data Storage and Retrieval System}

The National WATer Data STOrage and REtrieval System (WATSTORE) of the USGS was established in November 1971 to computerize the water data of the USGS and to provide for more effective and efficient management of its data-related activities. The system is operated and maintained on the central computer facilities of the USGS at its National Center in Reston, Va., and on computers in District offices throughout the Nation as part of the Distributed Information System. Data may be obtained from WATSTORE through the 48 District Offices of the USGS Water Resources Division. General inquiries about WATSTORE may be directed to:

Chief Hydrologist

U.S. Geological Survey

437 National Center

Reston, VA 22092

(703) 648-5215 or

U.S. Geological Survey

Water Resources Division

102 East Main Street, 4th Floor

Urbana, IL 61801

Phone: (217) 398-5353 


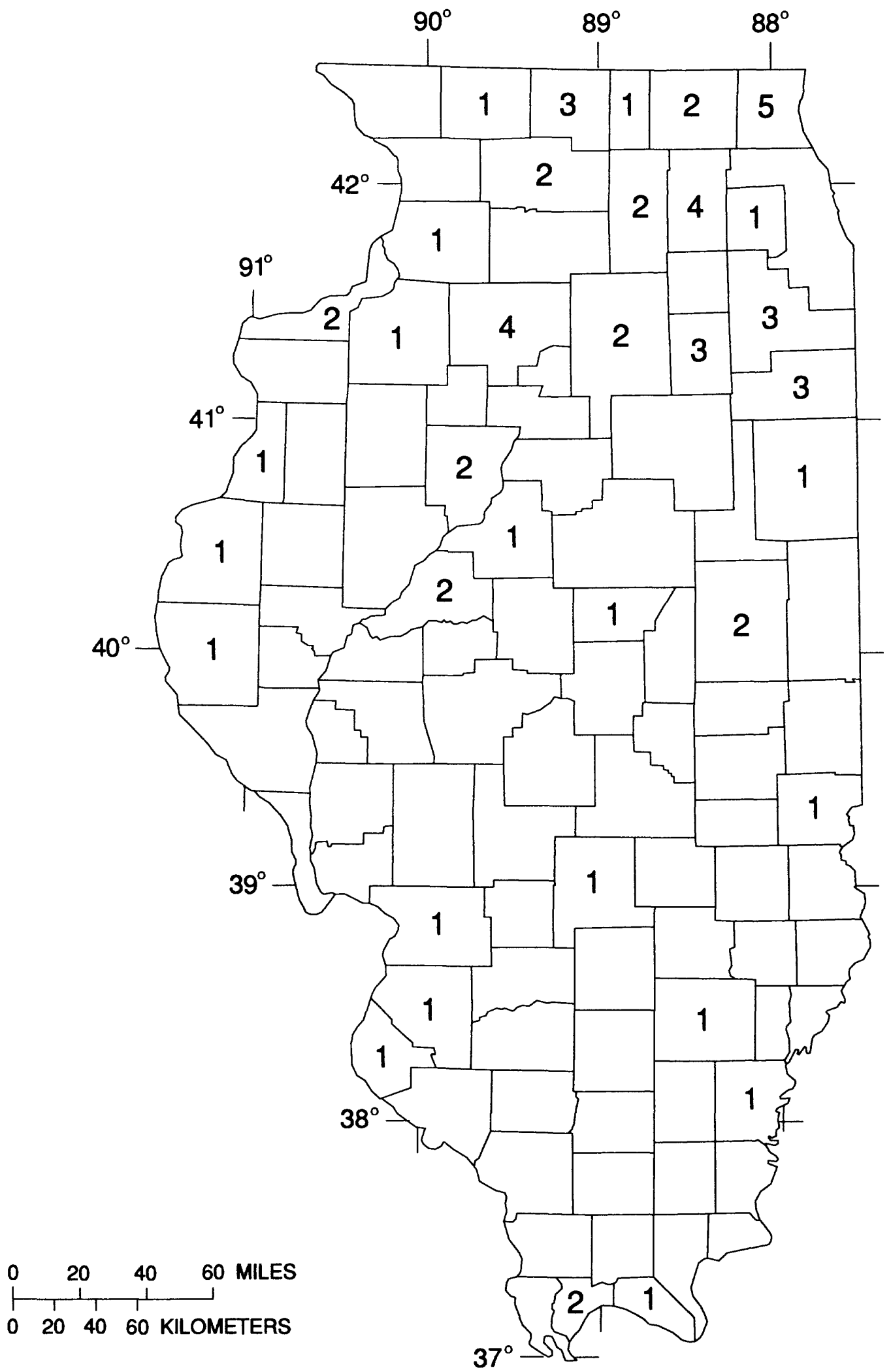

Figure 10. Ground-water stations operated by the Illinois District, by county, 1993. 


\section{National Water-Data Exchange}

The NAtional Water-Data EXchange (NAWDEX) is an interagency program to facilitate the exchange of water data and to promote the improvement of water-data handling procedures. Participants in the NAWDEX program are Federal, State, and local governments and interstate, academic, and private organizations that collect, store, and use water data. NAWDEX is managed by a Program Office, which is administered by the Water Resources Division.

Services are available through the Program Office at the USGS National Center in Reston, Va., and a nationwide network of Assistance Centers in all 50 States, the District of Columbia, and Puerto Rico, which provide local and convenient access to NAWDEX facilities. A directory of assistance centers (Blackwell, 1993) that provides names of organizations and persons to contact, as well as addresses, telephone numbers, and office hours for each of these organizations, is available on request.

The NAWDEX program can assist any organization or individual in identifying and locating water data. To accomplish this service, NAWDEX maintains a computerized Master Water-Data Index that identifies sites for which water data are available, the type of data available for each site, and the organization retaining the data. The NAWDEX program also maintains a Water-Data Sources Directory identifying organizations from which water data may be obtained. In addition, NAWDEX has direct access to some large water-data bases of its members and has reciprocal agreements for the exchange of services with others. For additional information concerning the NAWDEX program or its services contact:

Program Office

National Water Data Exchange (NAWDEX)

U.S. Geological Survey

421 National Center

12201 Sunrise Valley Drive

Reston, VA 22092

Phone: (703) 648-6848

Hours: $7: 00$ to $4: 30$ eastern time or NAWDEX Assistance Center

Illinois

U.S. Geological Survey

Water Resources Division

102 East Main Street, 4th Floor

Urbana, IL 61801

Phone: (217) 398-5353

Hours: $8: 00$ to $4: 30$ central time 


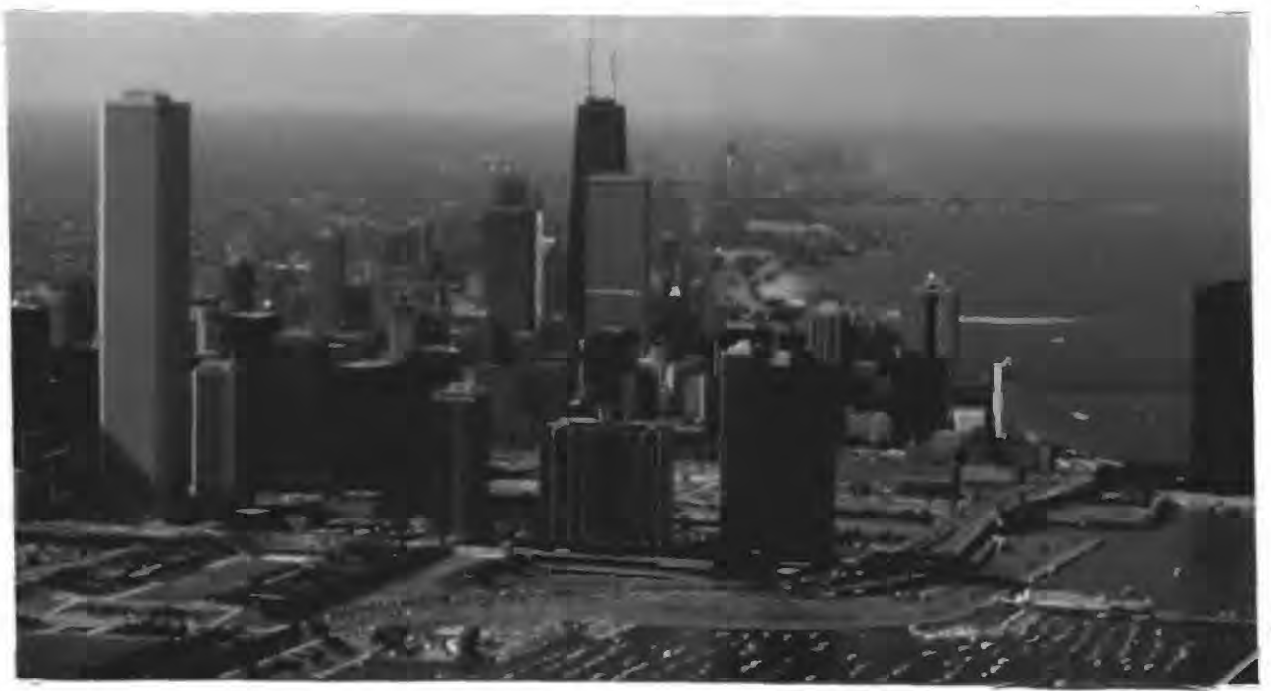

Looking north along Lake Michigan and the Chicago skyline

\section{DESCRIPTIONS OF PROJECTS IN 1993}

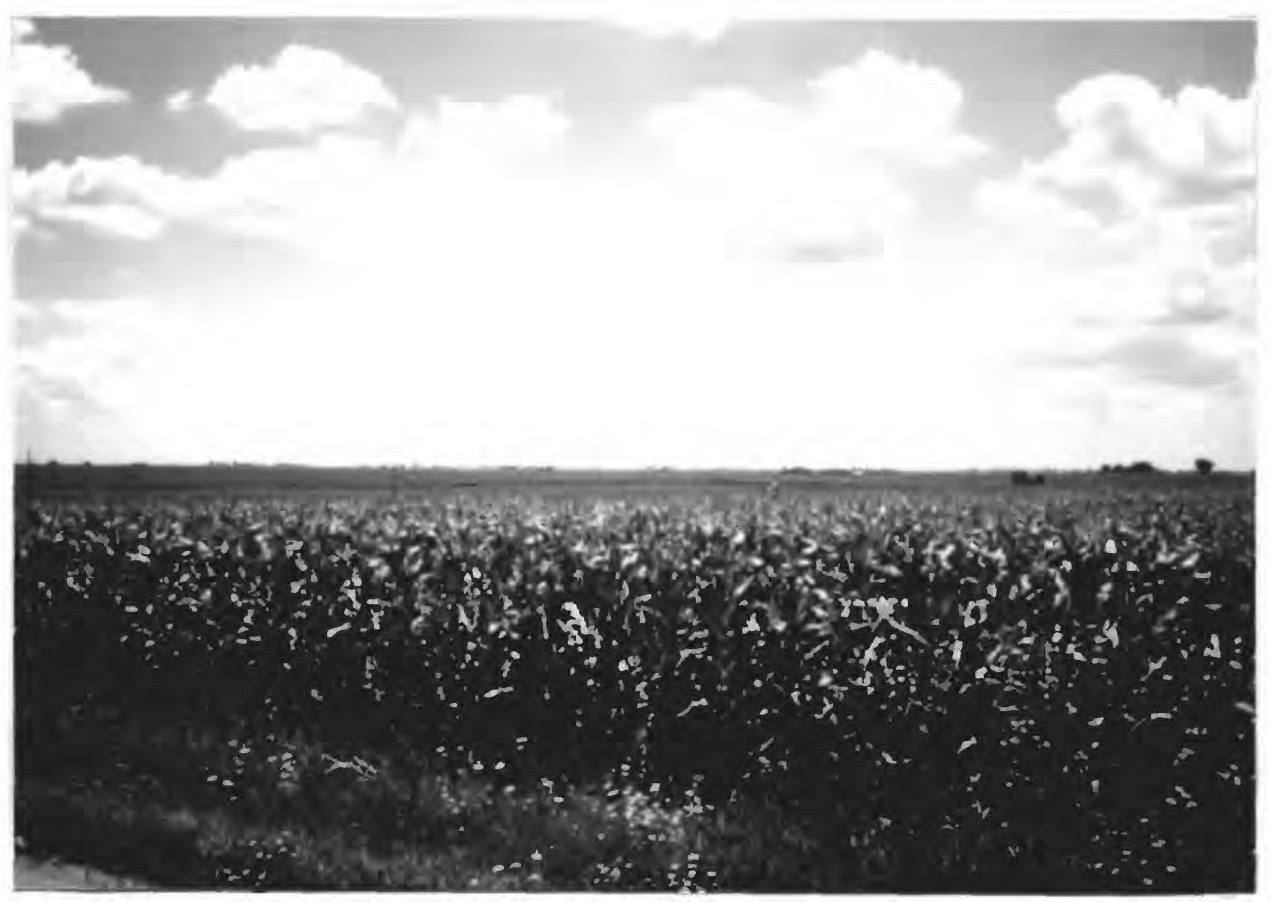

Water and sunshine helped to produce a bountiful crop of corn in central Illinois 


\section{IL001 SURFACE-WATER STATIONS}

LOCATION: Statewide

PROJECT CHIEF:

John K. LaTour

Urbana

PERIOD OF PROJECT:

Continuous since July 1930

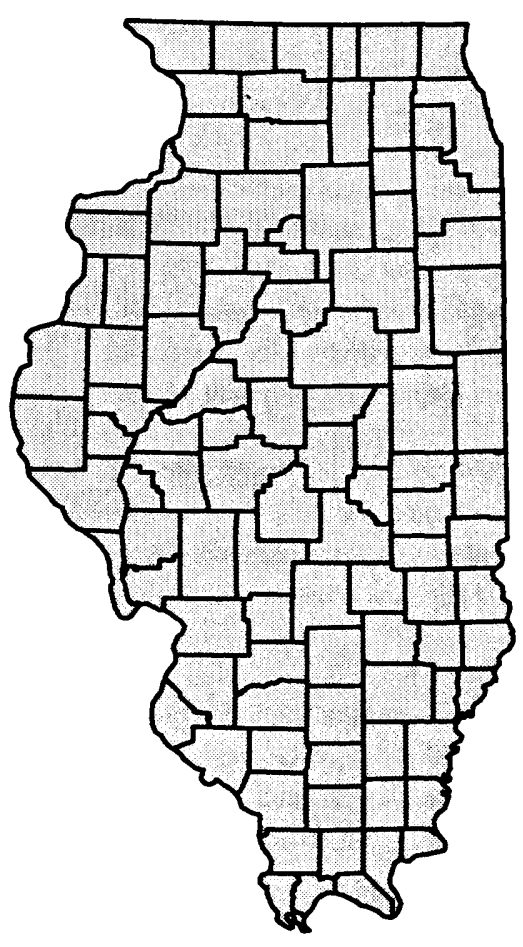

\section{COOPERATORS:}

Illinois Department of Transportation, Division of Water Resources; Illinois Department of Energy and Natural Resources, State Water Survey; Winnebago County Department of Public Works; The Metropolitan Water Reclamation District of Greater Chicago; Bloomington and Normal Sanitary District; Vermilion County Conservation District; Du Page County Department of Environmental Concerns; Forest Preserve District of Cook County; Forest Preserve District of Du Page County; Kane County Development Department; Danville Sanitary District; City of De Kalb; City of Decatur; City of Monticello; City of Springfield; Boneyard Creek Commission; U.S. Army Corps of Engineers: Rock Island District, St. Louis District, Louisville District, Chicago District

PROBLEM: Surface-water information is needed for surveillance, planning, design, hazard warning, operation, and management, in waterrelated fields such as water supply, hydroelectric power, flood control, irrigation, bridge and culvert design, wildlife management, pollution abatement, flood-plain management, and water-resources development. An appropriate data base is necessary to provide this information.

OBJECTIVES: A. To collect surface-water data sufficient to satisfy information needs for current purposes, such as (1) assessment of water resources, (2) operation of reservoirs or industries, (3) forecasting, (4) disposal of wastes and pollution controls, (5) assessment of streamwater quality, (6) compact and legal requirements, and (7) research or special studies. B. To collect data necessary for analytical studies to define, for any location, the statistical properties of, and trends in, the occurrence of water in streams and lakes for use in planning and design.

APPROACH: Standard methods of data collection will be used as described in the USGS report series, "Techniques of Water-Resources Investigations of the USGS." Partial-record gaging will be used instead of complete-record gaging where it serves the required purpose.

SUMMARY OF RESULTS: Routine data collection of surface-water information was done for 144 continuous-record streamflow-gaging stations, 12 partial-record stations, and 15 stage-only stations. Data for the 1992 water year were published in the annual data report.

PLANS: Continue surface-water data collection with modifications to the data network. Replace digital recorders with data loggers (stage recorders) and telephone modems. Replace manometers with pressure sensors. Repair or rebuild gages damaged by the flood. Organize how data are stored in the Automated DAta Processing System 
(ADAPS)-one discharge and multiple gage heights per station. Continue the collection of flood-related data at sites affected by the Mississippi River. Develop network of gage observers through the "River Watchers," a statewide organization of over 100 high schools. Publish data in the annual data report.

\section{PUBLISHED REPORTS:}

LaTour, J.K., Richards, T.E., and Coupe, R.H., 1993, Water resources data - Illinois, water year 1992, volume 2, Illinois River Basin: U.S. Geological Survey WaterData Report IL-92-2, 315 p.
Maurer, J.C., Richards, T.E., LaTour, J.K., and Coupe, R.H., 1993, Water resources data - Illinois, water year 1992, volume 1, Illinois except Illinois River Basin: U.S. Geological Survey Water-Data Report IL-92-1, $261 \mathrm{p}$. 


\section{ILO02 GROUND-WATER STATIONS}

COOPERATOR:

Federal Program

LOCATION: Statewide

PROJECT CHIEF:

Charles F. Avery

Urbana

PERIOD OF PROJECT:

Continuous since April 1982

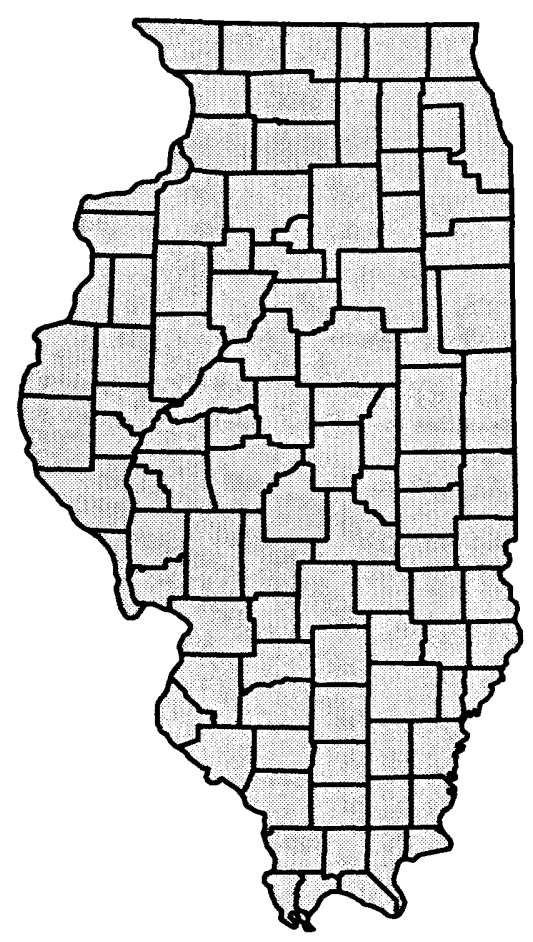

PROBLEM: Water-resource planning and ground-water quantity and quality assessment require a statewide base level of relatively standardized data. In Illinois, concentrated urbanization in the northeastern corner and intense farming and mining in much of the State require monitoring of ground water to assess the impact of man's activities on present and potential water uses.

OBJECTIVES: To provide high quality data from a network of monitoring stations across the State and to achieve timely dissemination of data from this network, to all potential users, in a readily usable form.

APPROACH: Coordinate ground-water data-gathering efforts with State, local, and other Federal agencies in Illinois. Efforts will be directed to having all participants use current and uniform datacollection and reporting procedures. Data collection is planned to meet site-specific needs and to provide a statewide baseline of information from which to evaluate the general status of the State's ground-water quantity and quality.

SUMMARY OF RESULTS: Measured water levels in one well in Du Page County, three piezometers and one well in Lake County, two wells in Bureau County, one well in De Kalb, County, one well in Winnebago County, one well in Ogle County, one well in Kane County, and one well in Grundy County. Data for the 1992 water year were published in the annual data report.

PLANS: Continue water-level data collection. Add one or two observation wells, to be measured quarterly, to the network. Collect water samples for analysis at two or three sites. Publish data in the annual data report.

\section{PUBLISHED REPORTS:}

LaTour, J.K., Richards, T.E., and Coupe, R.H., 1993, Water resources data - Illinois, water year 1992, volume 2, Illinois River Basin: U.S. Geological Survey Water-Data Report IL-92-2, 315 p.

Maurer, J.C., Richards, T.E., LaTour, J.K., and Coupe, R.H., 1993, Water resources data - Illinois, water year 1992, volume 1, Illinois except Illinois River Basin: U.S. Geological Survey Water-Data Report IL-92-1, 261 p. 


\section{IL003 QUALITY OF WATER STATIONS}

COOPERATORS:

Forest Preserve District of

Du Page County

Federal Program

LOCATION: Statewide

PROJECT CHIEF:

Richard H. Coupe, Jr.

Urbana

PERIOD OF PROJECT:

Continuous since June 1967

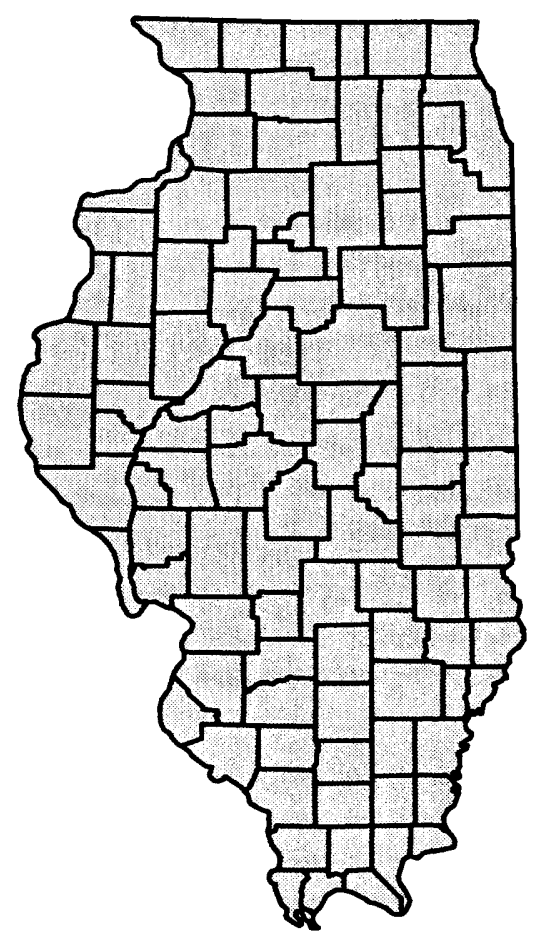

PROBLEM: Water-resource planning and water-quality assessment require a statewide base level of relatively standardized data. In Illinois, dense urbanization, especially in the northeastern corner, and intense farming and mining in other parts of the State require monitoring to assess the impact of man's activities on present and potential water uses.

OBJECTIVES: To provide high quality data to assist the cooperator with their water-resource planning and management needs

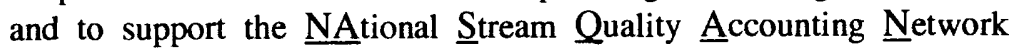
(NASQAN) by collecting high-quality, nationally consistent waterquality data. To achieve timely dissemination of water-quality data, to all potential users, in a readily usable form.

APPROACH: Coordinate surface-water-quality data-gathering efforts among the USGS and State, local, and other Federal agencies in Illinois. Efforts will be directed toward having all participants use current and uniform sampling, analytical, and data-reporting procedures. Sampling and data collection are tailored to meet sitespecific needs and to supply a baseline of information from which to evaluate the general nature of the State's surface-water quality.

SUMMARY OF RESULTS: Quality-assurance programs applied to field data collection and laboratory activities have continued. All data from the USGS National Water-Quality Laboratory have been reviewed and prepared for publication. Discharge values have been applied to the chemical data. Data for the 1992 water year were published in the annual data report.

PLANS: Collect water-quality data at six NASQAN stations and one cooperator site. Publish data in the annual data report.

\section{PUBLISHED REPORTS:}

Coupe, R.H., and Johnson, G.P., 1991, Triazine herbicides in selected streams in Illinois during storm events, spring 1990, in Mallard, G.E., and Aronson, D.A., eds., U.S. Geological Survey Toxic Substances Hydrology Program: U.S. Geological Survey OpenFile Report 91-088, p. 65.

LaTour, J.K., Richards, T.E., and Coupe, R.H., 1993, Water resources data - Illinois, water year 1992, volume 2, Illinois River Basin: U.S. Geological Survey Water-Data Report IL-92-2, 315 p.

Maurer, J.C., Richards, T.E., LaTour, J.K., and Coupe, R.H., 1993, Water resources data - Illinois, water year 1992, volume 1, Illinois except Illinois River Basin: U.S. Geological Survey Water-Data Report IL-92-1, $261 \mathrm{p}$.

Tarte, S.R., Schmidt, A.R., and Sullivan, D.J., 1992, Floating samplecollection platform with stage-activated automatic water sampler for streams with large variation in stage: U.S. Geological Survey Open-File Report 92-149, 14 p. 


\section{IL004 SEDIMENT STATIONS}

\section{COOPERATOR:}

U.S. Army Corps of Engineers, St. Louis District

U.S. Army Corps of Engineers, Rock Island District

\section{LOCATION: Statewide}

\section{PROJECT CHIEF:}

Richard H. Coupe, Jr.

Urbana

\section{PERIOD OF PROJECT:}

Continuous since January 1976

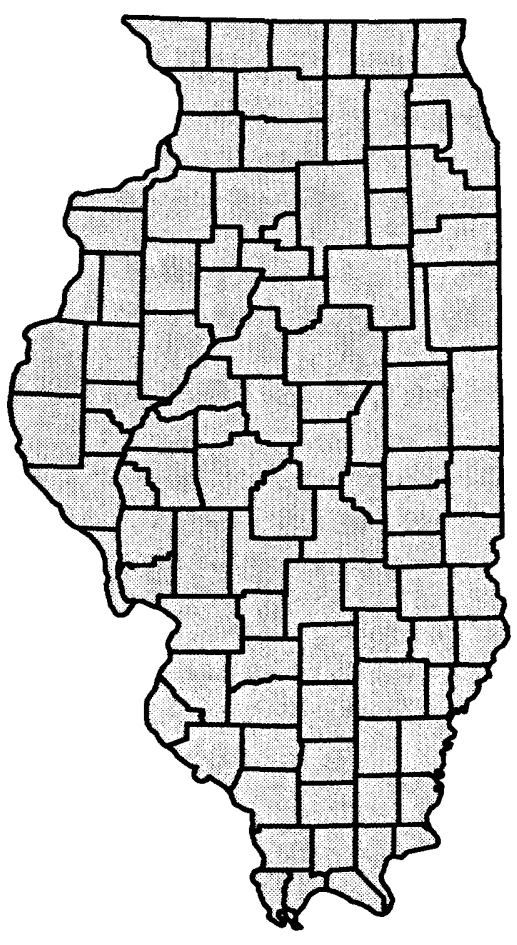

PROBLEM: Water-resource planning and water-quality assessment require a nationwide base level of information. Sediment concentrations and discharges in streams must be defined and monitored. A large percentage of the land in Illinois is devoted to agriculture whereby the land is exposed to erosion. Recent studies conducted under Section 208 of Public Law 92-500 have suggested sediment may be a major cause of water-quality degradation in Illinois. Other activities, such as highway construction and industrial and residential development, contribute sediment to streams. Planning and regulatory agencies need a data base to evaluate sediment transport in streams.

OBJECTIVES: To provide a data base for evaluating sediment problems in Illinois and a base from which the effectiveness of erosion control programs can be evaluated for their effect on water quality. To contribute to the national base of sediment data for use in broad Federal and State planning and action programs and to provide data for Federal management of interstate waters.

APPROACH: Establish and operate a network of sediment stations on Illinois streams to develop records of daily discharge of suspended sediment. Suspended-sediment stations will be located at long-term continuous-record surface-water discharge stations and will be used to establish relations between suspended-sediment discharge and surfacewater discharge. These relations will be used to estimate long-term suspended-sediment yields of selected basins and predominant land-use areas. Supplementary information at most stations will include particle-size determinations of suspended-sediment and bed-material samples.

SUMMARY OF RESULTS: Suspended-sediment samples were collected and analyzed, and daily suspended-sediment concentrations and loads were computed for five continuous-streamflow sites. Data for the 1992 water year were published in the annual data report.

PLANS: Continue sediment monitoring at five continuousstreamflow stations. Publish data in the annual data report.

\section{PUBLISHED REPORTS:}

LaTour, J.K., Richards, T.E., and Coupe, R.H., 1993, Water resources data - Illinois, water year 1992, volume 2, Illinois River Basin: U.S. Geological Survey Water-Data Report IL-92-2, 315 p.

Maurer, J.C., Richards, T.E., LaTour, J.K., and Coupe, R.H., 1993, Water resources data - Illinois, water year 1992, volume 1, Illinois except Illinois River Basin: U.S. Geological Survey Water-Data Report IL-92-1, 261 p. 


\section{IL006 FLOOD INVESTIGATIONS}

\section{COOPERATOR:}

Federal Emergency

Management Agency

LOCATION: Statewide

PROJECT CHIEF: Charles S. Melching

Urbana

PERIOD OF PROJECT: July 1993 - September 1994
PROBLEM: The National Flood Insurance Act of 1968 and the Flood Disaster Protection Act of 1973 provide for the operation of a flood insurance program. The Federal Emergency Management Agency (FEMA) needs flood studies in selected areas to determine applicable flood insurance premium rates.

OBJECTIVES: To perform the necessary hydrologic and hydraulic evaluations and studies of areas assigned by the FEMA and to present the results in an appropriate format.

APPROACH: To perform the necessary evaluations or to perform surveys by ground or photogrammetric methods. Determine flooddischarge frequency relations utilizing local historical information, gagingstation records, or other applicable information. Determine water-surface profiles using the step-backwater models or by other acceptable methods and furnish the results in reports prepared to FEMA specifications.

SUMMARY OF RESULTS: Developed plans and methodologies for the hydrologic evaluation of discharges of the Ebner Coulee box culvert in La Crosse, Wisconsin.

PLANS: Evaluate the 10-, 50-, 100-, and 500-year discharges for Ebner Coulee and determine the boundaries of the regulatory flood plain considering the operation of the Ebner Coulee box culvert. Discuss preliminary hydrologic evaluation and flood-plain boundaries with Wisconsin Department of Natural Resources and City of La Crosse, and develop final flood-plain map for submission to FEMA.

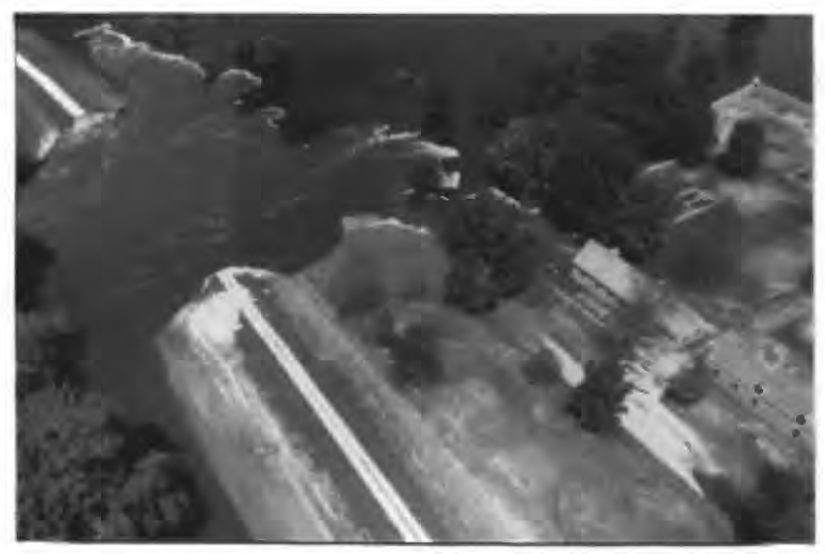

A levee break on the Illinois side of the Mississippi River during the 1993 flood 


\section{IL007 WATER USE}

\section{COOPERATORS:}

Board of Trustees of the University of Illinois, State Water Survey Illinois Environmental Protection Agency

\section{LOCATION: Statewide}

\section{PROJECT CHIEF:}

John K. LaTour

Urbana

\section{PERIOD OF PROJECT:}

Continuous since March 1978

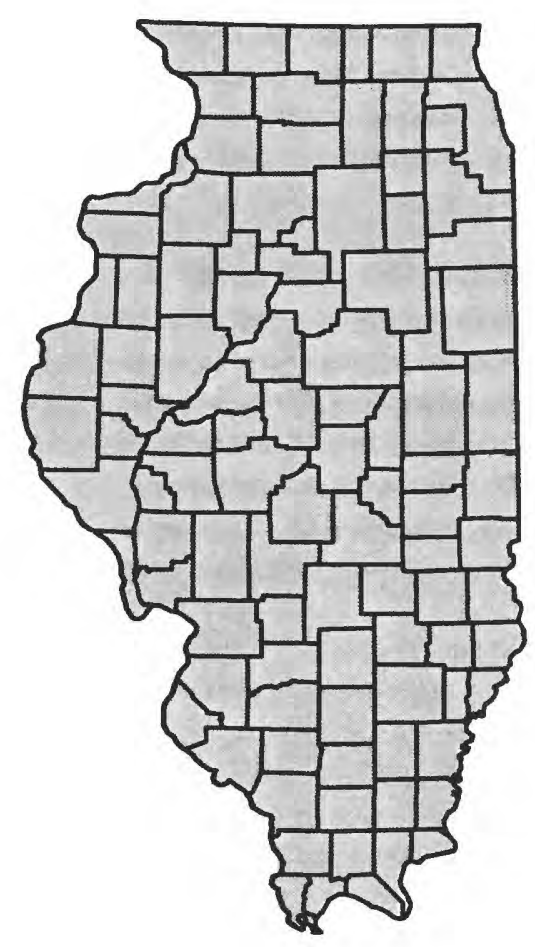

PROBLEM: A water supply may or may not be adequate depending upon present and future demands. Detailed information is being collected describing the quantity and quality of available water in Illinois. However, water-use inventories generally have been performed only intermittently or when a water supply has been adversely affected. Competing demands for water in Illinois dictate that adequate water-use information is essential for the proper management of available supplies.

OBJECTIVES: (1) Acquire water-use information throughout the State of Illinois as a basis for present analyses and future projections of water use. (2) Develop and maintain a water-use data base that will be responsive to the data needs of users at local, State, and national levels. (3) Establish methods of estimating water use.

APPROACH: Responsibilities will be divided between the Illinois State Water Survey (ISWS), the Illinois Environmental Protection Agency (IEPA), and the USGS. The ISWS will obtain waterwithdrawal and delivery data from questionnaires that they send to water users throughout the State. The ISWS and USGS will enter the data into a site-specific data base that is usable to both agencies. The USGS will transfer the statewide data into the Site-Specific Water Use Data System (SSWUDS).

The IEPA will obtain return data by way of the National Pollutant Discharge Elimination System. The IEPA and USGS will enter the data into a data base. The USGS will maintain the statewide return data in SSWUDS. The withdrawal, delivery, and return data will be aggregated by water-use category (water supply, commercial, industrial, fossil-fuel power, nuclear power, mining, hydroelectric, and sewage treatment) and location (county, hydrologic unit, and aquifer). Water uses by other categories (domestic, livestock, irrigation, and reservoir evaporation) will be estimated. The aggregations are done to meet State and national data needs.

SUMMARY OF RESULTS: In cooperation with the ISWS, 1992 withdrawal and delivery data were obtained. Data for 1990 were aggregated by category and location and entered into the Aggregated Water-Use Data System (AWUDS). In cooperation with the IEPA, 1992 return data were obtained for entry into SSWUDS. A report titled "Contribution of Return Flows to Streamflow in Selected Stream Reaches in Illinois" was published. A manual for the entry of return data into SSWUDS was written for application in the Illinois District.

PLANS: (1) Aggregate and enter 1991 water-use data into AWUDS. (2) Obtain 1990-92 site-specific withdrawal data. (3) Obtain 1993 return data. (4) Assign downstream-order numbers to return sites in SSWUDS for integration into the National Water Information System (NWIS) site file. (5) Integrate ISWS site-specific withdrawal data with return data and merge into SSWUDS. 


\section{PLANNED REPORTS:}

Water withdrawals in Illinois, 1988

Water withdrawals in Illinois, 1990

\section{PUBLISHED REPORTS:}

Kirk, J.R., Jarboe, Jacquelyn, Sanderson, E.W., Sasman, R.T., and Sinclair, R.A., 1979, Water withdrawals in Illinois, 1978: Illinois State Water Survey Circular 140, 34 p.

Kirk, J.R., Jarboe, Jacquelyn, Sanderson, E.W., Sasman, R.T., and Lonnquist, Carl, 1982, Water withdrawals in Illinois, 1980: Illinois State Water Survey Circular 152, 47 p.

Kirk, J.R., Sanderson, E.W., and Sasman, R.T., 1984, Water withdrawals in Illinois, 1982: Illinois State Water Survey Circular 161, 43 p.
Kirk, J.R., Hlinka, K.J., Sasman, R.T., and Sanderson, E.W., 1985, Water withdrawals in Illinois, 1984: Illinois State Water Survey Circular 163, 43 p.

Kirk, J.R., 1987, Water withdrawals in Illinois, 1986: Illinois State Water Survey Circular 167, 43 p.

LaTour, J.K., 1991, Determination of water use in Rockford and Kankakee areas, Illinois: U.S. Geological Survey Water-Resources Investigations Report 90-4166, 70 p.

1993, Contribution of return flows to streamflow in selected stream reaches in Illinois, 1988-89: U.S. Geological Survey Water-Resources Investigations Report 93-4089, 35 p.

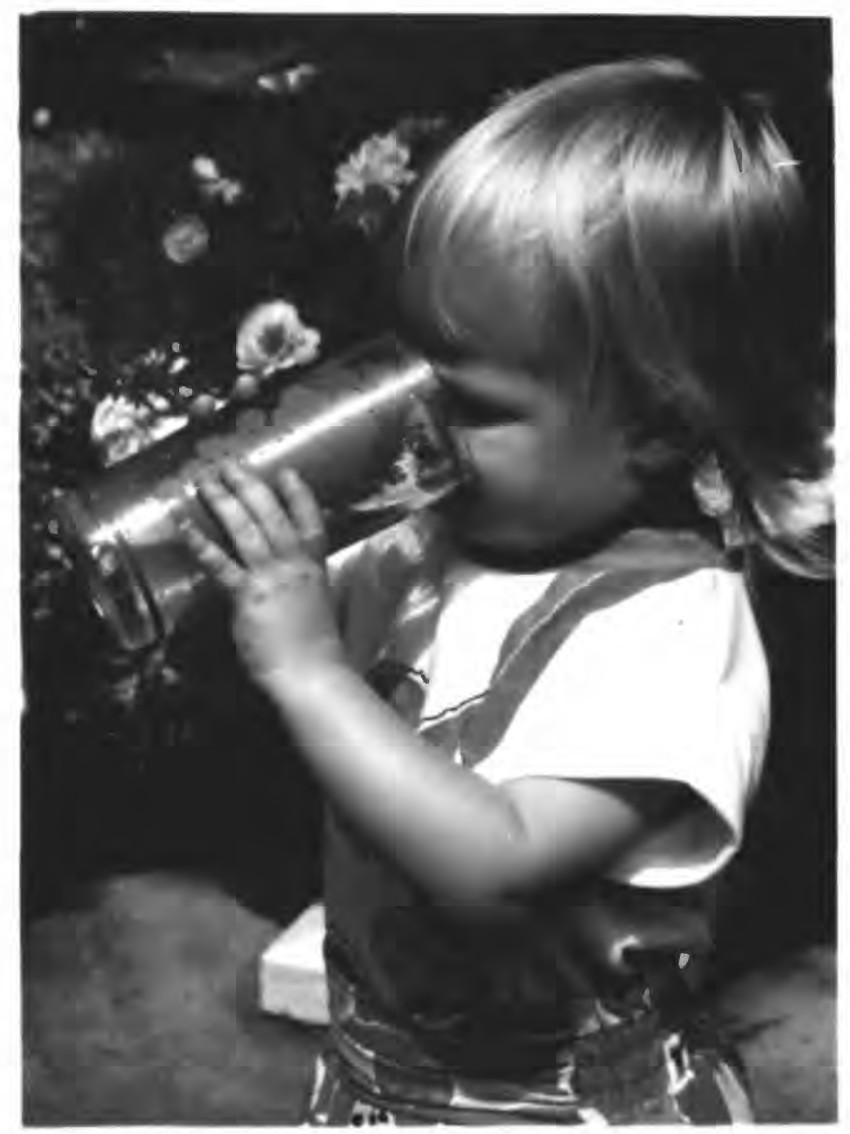

Enjoying a cool glass of clear, clean water on a hot Fourth of July 


\section{IL075 UPPER ILLINOIS RIVER BASIN WATER-QUALITY ASSESSMENT}

\section{COOPERATOR: \\ Federal Program}

\author{
LOCATION: Upper Illinois \\ River Basin
}

PROJECT CHIEF:

Arthur R. Schmidt

Urbana

\section{PERIOD OF PROJECT:}

Continuous since April 1986

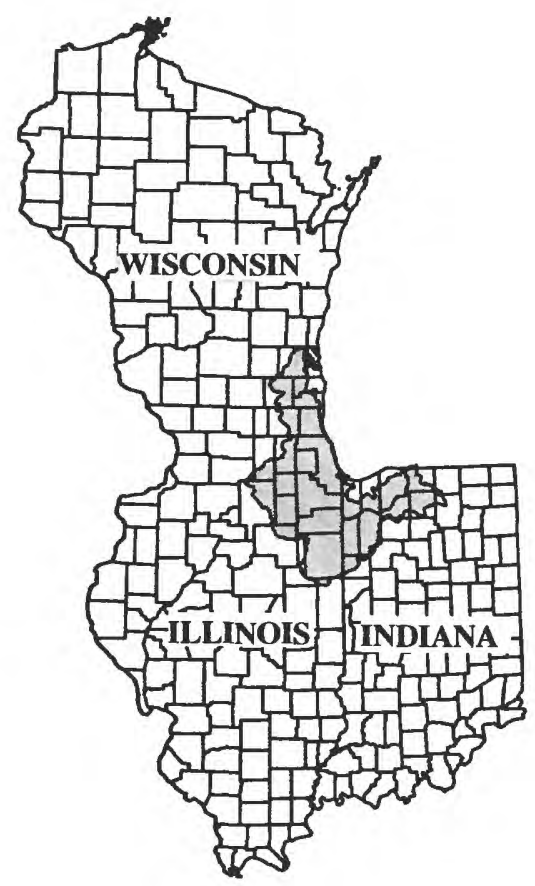

PROBLEM: Protecting the quality of the Nation's ground-water and surface-water resources is a priority national concern. The quality of the Nation's water resources has a direct effect on public health and on the economic success of agriculture, industry, and recreation. The impact of degraded water quality may have short- or long-term effects on public health or economic success. In 1986, the USGS initiated a NAtional Water-Quality Assessment (NAWQA) program to help address problems related to degraded water quality. This program is in a pilot phase that will test, and modify as necessary, concepts and approaches in preparation for possible full implementation in the future. The upper Illinois River Basin project is one of seven pilot water-quality studies initiated in the pilot phase of the NAWQA program.

OBJECTIVES: (1) Provide a description of present surfacewater-quality conditions. (2) Develop conceptual models that relate observed conditions to sources and causes. (3) Track long-term trends in water quality. (4) Improve the understanding of the relation between causative factors and water quality.

APPROACH: A liaison committee consisting of representatives of Federal, State, and local agencies will be formed to provide a forum for the USGS to inform interested parties of NAWQA plans and findings, to seek advice, to identify available data and reports, and to establish collaborative efforts to supplement the NAWQA program. Available data and reports will be compiled and summarized to provide a description of past and current trends in conditions. Descriptive information that may aid in the interpretation of trends will be compiled. Simple statistical methods, such as regression analysis, will be used to relate observed trends to the descriptive information. New data will be collected from the operation of a fixed-location riversampling station network and from synoptic surveys. Reports describing project plans, data, and findings will be published.

SUMMARY OF RESULTS: Substantial progress was made toward completing all planned reports. Data report on agricultural organics in water was approved. The report on analysis of available data was sent to Headquarters in June for approval. The report on relation of changes in treatment plants to changes in water quality was approved. The other planned reports have all completed colleague review and only need a technical editorial review prior to submission for Director's approval.

PLANS: Continue to summarize and interpret water-quality data for the basin. Complete and publish all planned reports for the project. 


\section{PLANNED REPORTS:}

Trace elements in water, sediment, and biota, upper Illinois River Basin

Organic compounds in water, sediment, and biota, upper Illinois River Basin

Nutrients, dissolved oxygen, and fecal-indicator bacteria, upper Illinois River Basin

\section{REPORTS IN PROCESS:}

Water-quality assessment of the upper Illinois River Basin in Illinois, Indiana, and Wisconsin: Analysis of available surface-water-quality data through 1986

Relations of changes in wastewater-treatment practices to changes in stream-water quality during 1978-88 in the Chicago area, Illinois, and implications for regional and national water-quality assessments

Surface-water-quality assessment of the upper Illinois River Basin in Illinois, Indiana, and Wisconsin: Fixedstation network, water-quality data, April 1987September 1990

Spatial distribution of trace elements in the fine-fraction of streambed sediment in the upper Illinois River Basin, 1987

Surface-water-quality assessment of the upper lllinois River Basin in Illinois, Indiana, and Wisconsin: Data on agricultural organic compounds in water, April 1988August 1990

\section{PUBLISHED ABSTRACTS AND PAPERS:}

Terrio, P.J., 1987, Methods for selecting bottom-material sampling sites in the upper Illinois River Basin, in Program and Abstracts, Illinois State Section of the American Water Resources Association, 1987 Annual Conference, April 28-29, 1987, Champaign, Ill., p. 32.

Blanchard, S.F., 1989, Surface-water quality of the upper Illinois River Basin in Illinois, Indiana, and Wisconsin-analysis of existing information, in Pederson, G.L., and Smith, M.M., comps., U.S. Geological Survey Second National Symposium on Water Quality: U.S. Geological Survey Open-File Report 89-409, p. 5.
Ruhl, P.M., and Striegl, R.G., 1989, Relations between fish population and water quality in the upper Illinois River Basin in Illinois, Indiana, and Wisconsin-analysis of existing information, in Pederson, G.L., and Smith, M.M., comps., U.S. Geological Survey Second National Symposium on Water Quality: U.S. Geological Survey Open-File Report 89-409, p. 80-81.

Smith, S.M., Sanzolone, R.F., and Colman, J.A., 1989, Use of multivariate techniques for background and anthropogenic-source analysis of trace elements in streambed materials in the upper Illinois River Basin in Illinois, Indiana, and Wisconsin, in Pederson, G.L., and Smith, M.M., comps., U.S. Geological Survey Second National Symposium on Water Quality: U.S. Geological Survey Open-File Report 89-409, p. 93.

Stanke, F.A., 1989, Using a geographic information system to relate human and natural factors to stream-water quality in the upper Illinois River Basin in Illinois, Indiana, and Wisconsin, in Pederson, G.L., and Smith, M.M., comps., U.S. Geological Survey Second National Symposium on Water Quality: U.S. Geological Survey Open-File Report 89-409, p. 96.

Terrio, P.J., 1989, Occurrence and distribution of nutrients and dissolved oxygen in the upper Illinois River Basin in Illinois, Indiana, and Wisconsin-results of a 1988 low-flow synoptic survey, in Pederson, G.L., and Smith, M.M., comps., U.S. Geological Survey Second National Symposium on Water Quality: U.S. Geological Survey Open-File Report 89-409, p. 100-101.

Terrio, P.J., 1991, Occurrence and distribution of nutrients, dissolved oxygen, and Escherichia Coli bacteria in the upper Illinois River Basin in Illinois, Indiana, and Wisconsin: Results of a 1988 low-flow synoptic survey, in Program and Abstracts, 1991 Annual Conference, Illinois State Section of the American Water Resources Association, October 21, 1991, Peoria, Ill.

Schmidt, A.R., 1992, Sediment and water quality in the upper Illinois River Basin, in Proceedings, 1991 Governor's Conference on the Management of the Illinois River System, October 22-23, 1991, Peoria, Ill., p. 78-87.

\section{PUBLISHED REPORTS:}

Mades, D.M., 1987, Surface-water-quality assessment of the upper Illinois River Basin in Illinois, Indiana, and Wisconsin: Project description: U.S. Geological Survey Open-File Report 87-473, 39 p. 
Steffeck, D.W., and Striegl, R.G., 1989, An inventory and evaluation of biological investigations that relate to stream-water quality in the upper Illinois River Basin of Illinois, Indiana, and Wisconsin: U.S. Geological Survey Water-Resources Investigations Report 89-4041, 54 p.

Zogorski, J.S., $\quad$ Blanchard, S.F., $\quad$ Romack, R.D., $\quad$ and Fitzpatrick, F.A., 1990, Availability and suitability of municipal wastewater information for use in a national water-quality assessment: A case study of the upper Illinois River Basin in Illinois, Indiana, and Wisconsin: U.S. Geological Survey Open-File Report 90-375, 68 p.
Colman, J.A., and Sanzolone, R.F., 1991, Surface-waterquality assessment of the upper Illinois River Basin in Illinois, Indiana, and Wisconsin: Geochemical data for fine-fraction streambed sediment from high- and low-order streams, 1987: U.S. Geological Survey Open-File Report 90-571, 108 p.

Fitzpatrick, F.A., and Colman, J.A., 1993, Surface-water quality assessment of the upper Illinois River Basin in Illinois, Indiana, and Wisconsin: Data on manmade nonagricultural volatile and semivolatile organic chemicals in water, May 1988 through March 1990: U.S. Geological Survey Open-File Report 92-467, $70 \mathrm{p}$.

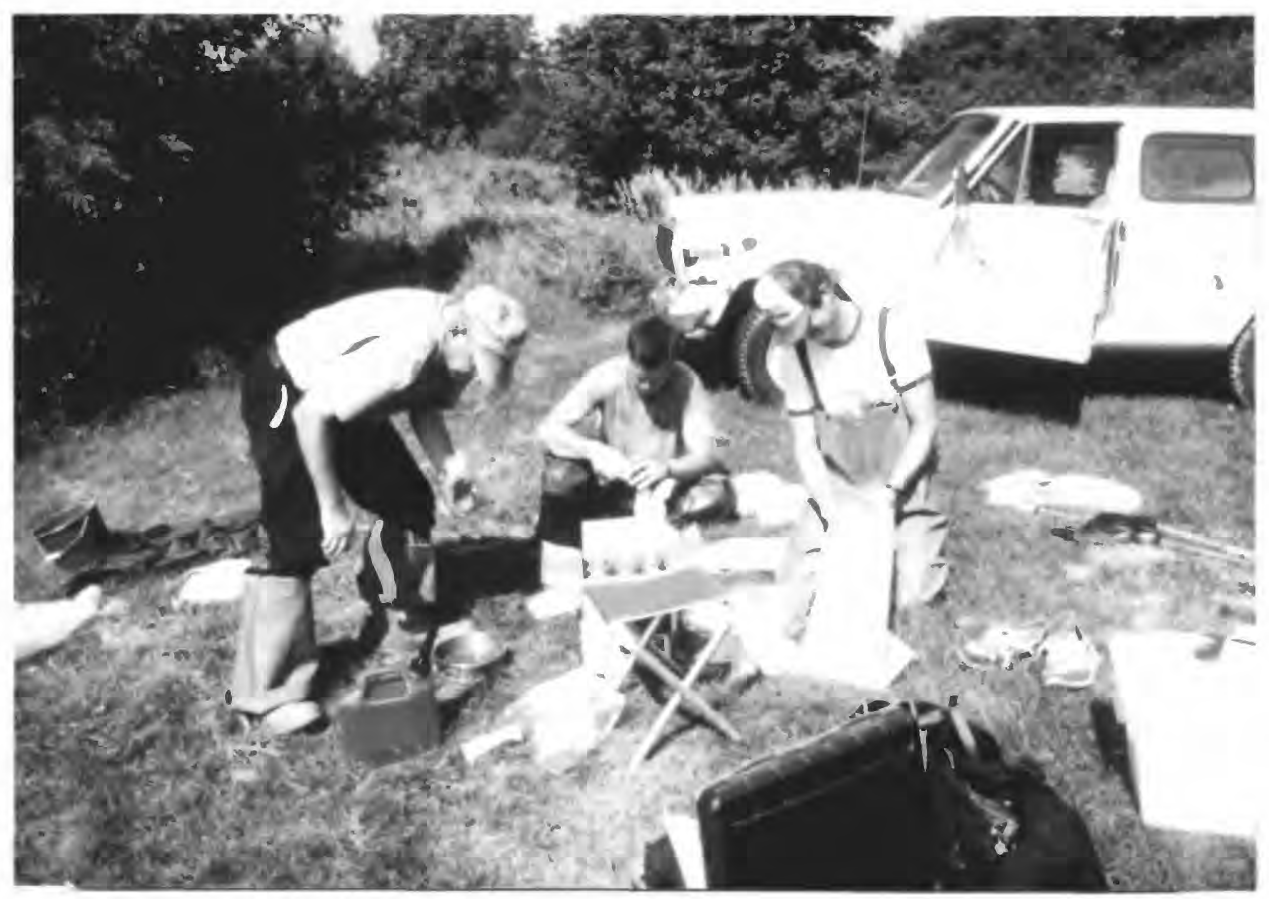

Preparing to sample for macroinvertebrates in streams in the upper Illinois River Basin 


\section{IL080 USGS/USEPA INTERAGENCY AGREEMENT PROJECTS}

COOPERATOR:

U.S. Environmental Protection

Agency, Region V

LOCATION: Statewide

PROJECT CHIEF:

Robert T. Kay

De Kalb

PERIOD OF PROJECT:

March 1986 through

September 1995

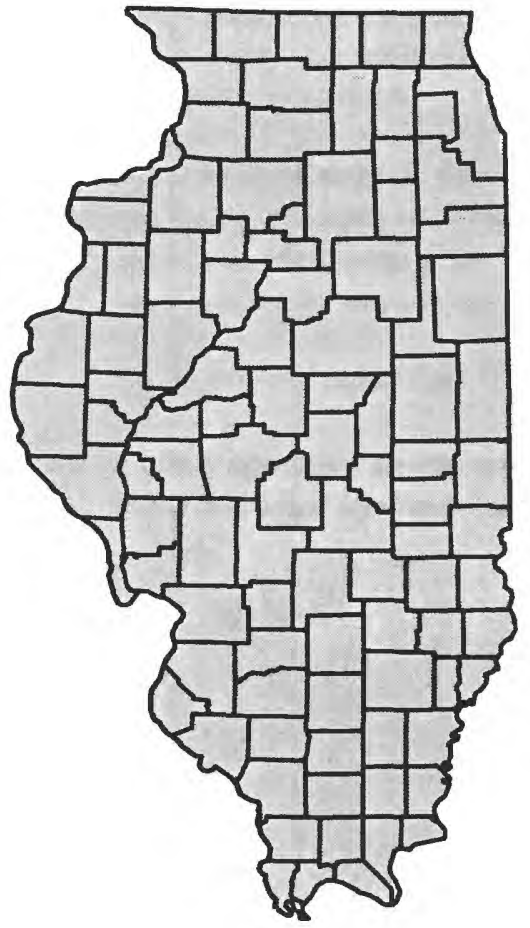

PROBLEM: The U.S. Environmental Protection Agency (USEPA), Region $\mathrm{V}$, has requested that the USGS, Illinois District, provide technical assistance on several Superfund sites within the State. The technical assistance varies from reviewing technical reports submitted to USEPA by their consultants to designing and performing hydrogeologic investigations at Superfund sites and regional areas of environmental concern.

OBJECTIVES: To provide technical consultation, training, and quality assurance and to perform investigations for the USEPA under the conditions of the Joint Interagency Agreement.

APPROACH: Design, perform, and analyze hydrogeologic and water-quality activities at the Southeast Rockford, Byron Salvage Yard, and Parson's Casket Superfund sites. Design and conduct area-wide hydrogeologic studies in the Belvidere area a large area in northern Illinois. Provide technical review on results of work at the HOD Landfill, Superior Street, and Tri-County Landfill. Write a report disclosing results of USGS data analysis of hydrogeologic conditions at Byron, Southeast Rockford, and Parson's sites, and Belvidere area.

SUMMARY OF RESULTS: Provided technical review of reports and work plans at the Tri-County Landfill, Southeast Rockford, HOD Landfill, Superior Street, and ACME Solvents sites. Received approval to publish results of study of ground-water/surface-water interactions, Byron Salvage Yard area. Completed field work on studies of hydrogeology and contaminant distribution in the fractured dolomite aquifers at Byron Salvage Yard and Parson's Casket sites. Related reports are in technical review. Began field work and data analysis for Belvidere and Galena-Platteville area studies. Relocated USGS employee at USEPA Region V office.

PLANS: Complete Water-Resources Investigations Report for fractured rock study at the Byron and Parson's Casket sites. Complete report writing for the water-quality study in the Belvidere area. Continue data collection and analysis for Galena-Platteville area study.

\section{PLANNED REPORTS:}

Ground-water/surface-water interactions, Byron Salvage Yard area Hydrogeology, aquifer tests, water-quality sampling, Byron Salvage Yard 


\section{PUBLISHED ABSTRACTS:}

Kay, R.T., Ryan, B.J., Mears, E.J., and Yeskis, D.J., 1987, Hydrogeology of the Byron/Johnson Salvage Yard Superfund site near Byron, Illinois, in Proceedings of the ASCE Water Resources Symposium, October 21-22, 1987, Rosemont, Ill.

Ryan, B.J., Kay, R.T., and Wallace, K.A., 1987, Hydraulic testing in two aquifers at a superfund site near Byron, Illinois, in Program with Abstracts, 32nd Annual Midwest Ground Water Conference, October 28-30, 1987, Madison, Wis.

Avery, C.F., Yeskis, D.J., and Bolen, W.F., 1991, Interaction of ground water with the Rock River near Byron, Illinois, in Programs and abstracts, American Geophysical Union 1991 Fall Meeting, December 9-13, 1991, San Francisco, Calif.

\section{PUBLISHED REPORTS:}

Kay, R.T., Olson, D.N., and Ryan, B.J., 1989, Hydrogeology and results of aquifer tests in the vicinity of a hazardous-waste disposal site near Byron, Illinois: U.S. Geological Survey Water-Resources Investigations Report 89-4081, 55 p.
Kay, R.T., and Earle, J.D., 1990, Determination of hydraulic properties in the vicinity of a landfill near Antioch, Illinois: U.S. Geological Survey Water-Resources Investigations Report 89-4124, 28 p.

Mills, P.C., 1993a, Vertical distribution of hydraulic characteristics and water quality in three boreholes in the Galena-Platteville Aquifer at the Parson's Casket Hardware superfund site, Belvidere, Illinois, 1990: U.S. Geological Survey Open-File Report 93-402, $36 \mathrm{p}$.

1993b, Hydrogeology and water quality of the GalenaPlatteville Aquifer at the Parson's Casket Hardware superfund site, Belvidere, Illinois, 1991: U.S. Geological Survey Open-File Report 93-403, 86 p.

1993c, Hydrogeology and water quality of the GalenaPlatteville Aquifer at the Parson's Casket Hardware superfund site, Belvidere, Illinois, 1991-1992: U.S. Geological Survey Open-File Report 93-404, $29 \mathrm{p}$.

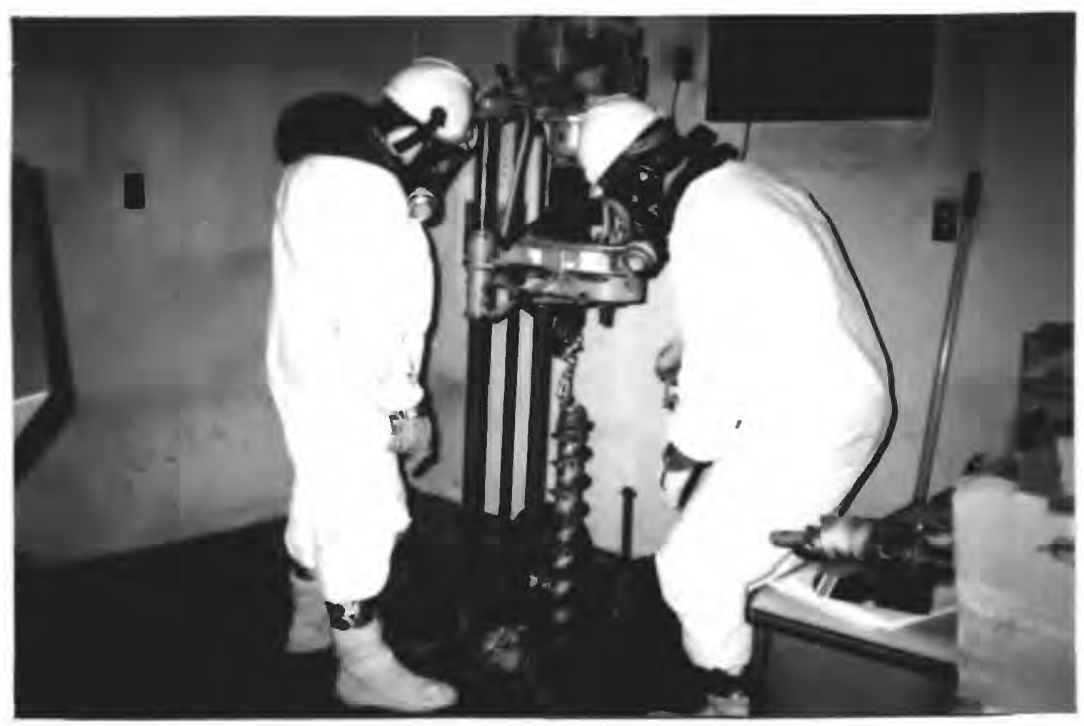

Personal protective equipment is necessary while working at hazardous materials Superfund sites 


\section{IL083 RAINFALL-RUNOFF RELATIONS IN THREE SMALL WATERSHEDS IN DU PAGE COUNTY}

COOPERATOR:

Du Page County, Department of Environmental Concerns

\section{LOCATION:}

Du Page County, Illinois

\section{PROJECT CHIEF:}

\author{
James J. Duncker
}

Urbana

\section{PERIOD OF PROJECT: \\ October 1987 through September 1994}

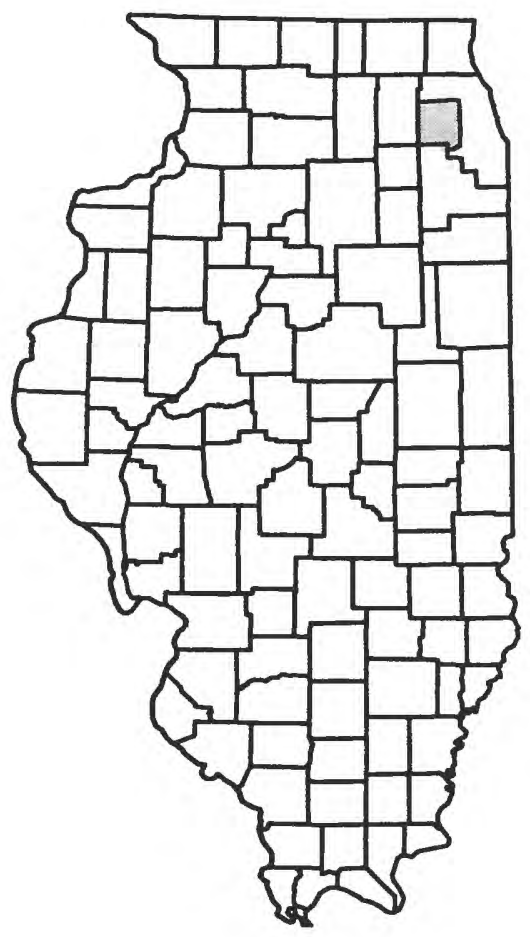

PROBLEM: Little information about the variation in time and space of rainfall and corresponding storm runoff exists in Du Page County. The development of a comprehensive, county-wide stormwater-management program in Du Page County requires an understanding of rainfall-runoff relations. Actual runoff data are needed for developing rainfall-runoff relations.

OBJECTIVES: (1) Determine rainfall-runoff relations in three small watersheds using observed data and rainfall-runoff modeling. (2) Analyze differences in rainfall-runoff relations between watersheds and relate differences to causative factors such as land use.

APPROACH: Streamflow and meteorologic data will be collected in three small watersheds in northeastern Illinois. Continuous records of stage and discharge will be collected in each watershed. At least three rain gages for each watershed will be installed. Other pertinent data, such as land use and soil type, will be obtained from available sources. These data will be used to calibrate a continuous simulation rainfall-runoff model for each watershed. A subset of the data collected will be reserved for model verification.

SUMMARY OF RESULTS: Streamflow and rainfall datacollection activities were continued throughout the year. Rainfallrunoff modeling of the three small watersheds is continuing using the revised land-cover data. Initial modeling results indicate significant differences in model parameters for the small watersheds related to soil characteristics (infiltration rates). Initial results also do not support the need for three slope categories of the grassland land cover.

PLANS: Data collection and analysis will continue throughout the 1994 fiscal year. Model calibration and verification for the three small watersheds will be completed by spring 1994 . The rainfall-runoff modeling report will also be completed during the 1994 water year.

\section{REPORT IN PROCESS:}

Rainfall-runoff relations in three small watersheds in Du Page County, Illinois

\section{PUBLISHED REPORT:}

Duncker, J.J., Vail, T.J., and Earle, J.D., 1993, Rainfall in and near Du Page County, Illinois, February 1986 - September 1991: U.S. Geological Survey Open-File Report 92-485, 142 p. 


\section{IL086 A STATISTICAL AND GRAPHICAL DESCRIPTION OF ILLINOIS GROUND-WATER QUALITY}

COOPERATOR:

Illinois Environmental Protection

Agency

LOCATION: Statewide

PROJECT CHIEF:

Kelly L. Warner

Urbana

PERIOD OF PROJECT:

August 1988 through September 1993

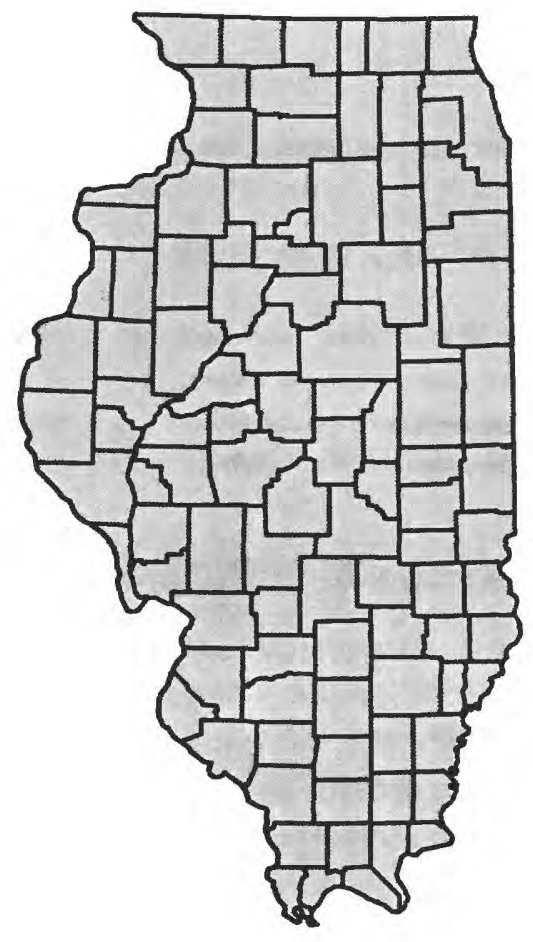

PROBLEM: The public water-supply well information collected by the Illinois Environmental Protection Agency (IEPA) and USGS constitutes the largest statewide ground-water water-quality data base. This information has never been statistically or graphically summarized. The new Illinois Ground Water Protection Act mandates new and continued assessment of Illinois ground-water quality.

OBJECTIVE: To statistically and graphically present ambient Illinois ground-water quality based on water-quality information from public water-supply wells.

APPROACH: Applications of the National Water Information System statistical packages and a geographic information system (GIS) will give accurate tabular and graphic representation of Illinois ground water. Correlations and spatial trends will be explored. A statewide ground-water-quality network will be designed and statistically evaluated.

SUMMARY OF RESULTS: September 1993 data were entered and checked. Stop format report concerning inorganic constituents in ground water was sent to colleague review. Continued sampling until September 30.

PLANS: Publish report on inorganic constituents in ground water from public-supply wells in Illinois. Document statistical approach for pesticide network design. Continue water-quality sampling.

\section{PLANNED REPORT:}

Trends in ground-water-quality data for public-supply wells in Illinois

\section{REPORT IN PROCESS:}

Inorganic constituent concentrations in ground water from public-supply wells in Illinois

\section{PUBLISHED ABSTRACT:}

Warner, K.L., and Wolfe, M.A., 1992, Application of a geographic information system to a ground-water-quality assessment in Illinois, in Program and Abstracts, Fifth Annual Midwest/Great Lakes User Conference, October 23-25, 1991, Indianapolis, Indiana.

\section{PUBLISHED REPORTS:}

LaTour, J.K., Richards, T.E., and Coupe, R.H., 1993, Water resources data - Illinois, water year 1992, volume 2, Illinois River Basin: U.S. Geological Survey Water-Data Report IL-92-2, 315 p.

Maurer, J.C., Richards, T.E., LaTour, J.K., and Coupe, R.H., 1993, Water resources data - Illinois, water year 1992, volume 1, Illinois except Illinois River Basin: U.S. Geological Survey Water-Data Report IL-92-1, $261 \mathrm{p}$. 


\section{IL089 RAINFALL-RUNOFF RELATIONS IN EIGHT WATERSHEDS IN LAKE COUNTY, ILLINOIS}

COOPERATOR:

Lake County Stormwater

Management Commission

\section{LOCATION:}

Lake County, Illinois

PROJECT CHIEF:

James J. Duncker

Urbana

PERIOD OF PROJECT:

June 1989 through September 1993

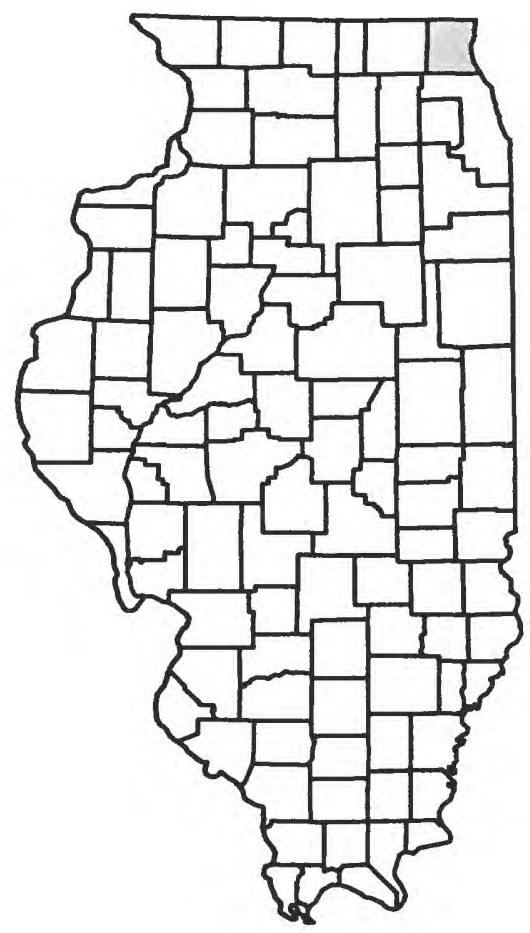

PROBLEM: Lake County, north of Chicago, is rapidly urbanizing. State legislation, partly prompted by recent record flooding, has given the county responsibility for stormwater management. To address this responsibility, county officials need knowledge of the rainfall-runoff relations for watersheds within the county, and how these relations may be affected by changing land-use and engineering constraints.

OBJECTIVES: (1) Determine the rainfall-runoff relations for eight watersheds in Lake County. (2) Define the rainfall-runoff relations for major land-use categories and soil types prevalent in the county.

APPROACH: (1) Establish a network of rainfall- and streamflow-gaging stations. (2) Calibrate and verify a distributedparameter rainfall-runoff model using the collected data. (3) Relate the hydrologic and hydraulic characteristics of the watersheds to the rainfall-runoff relations of the watersheds with regression analysis.

SUMMARY OF RESULTS: Streamflow and rainfall data collection continued through the end of the 1993 water year. Landcover analysis of the watersheds from aerial photography continues. Assistance in the land-cover analysis is being provided by the Ideas Laboratory at the National Mapping Division, Rolla, Missouri. Calibration and verification of the Hydrological $\underline{\text { Simulation }}$ Program-Fortran (HSPF) model was completed for five watersheds. HSPF calibration was also completed for the hydrologic response units.

PLANS: Publish two planned reports.

\section{PLANNED REPORT:}

Rainfall-runoff relations in Lake County, Illinois

\section{REPORT IN PROCESS:}

Rainfall in and near Lake County, Illinois, 1989-92

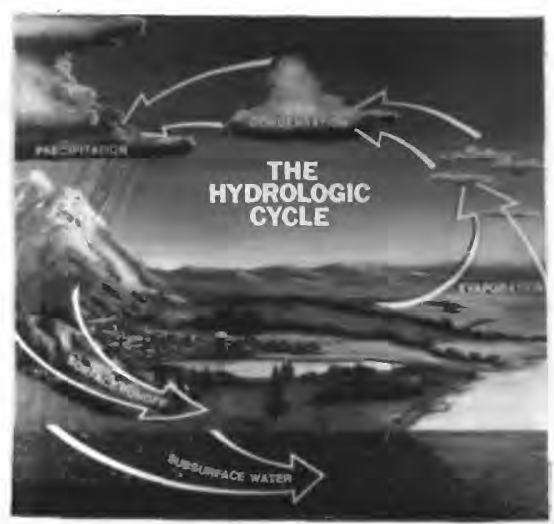

The Hydrologic Cycle: where does water come from and where does it go 


\section{IL093 USE OF CO-REGISTERED SLAR AND TM IMAGERY TO CLASSIFY AND MAP LAND COVER IN NORTHEASTERN ILLINOIS}

COOPERATORS:

Illinois Department of

Conservation

Kane County Forest Preserve

District

Kane County Development

Department

\section{LOCATION:}

Northeastern Illinois

PROJECT CHIEF:

Robin B. King

Urbana

PERIOD OF PROJECT:

January 1991 through March 1993

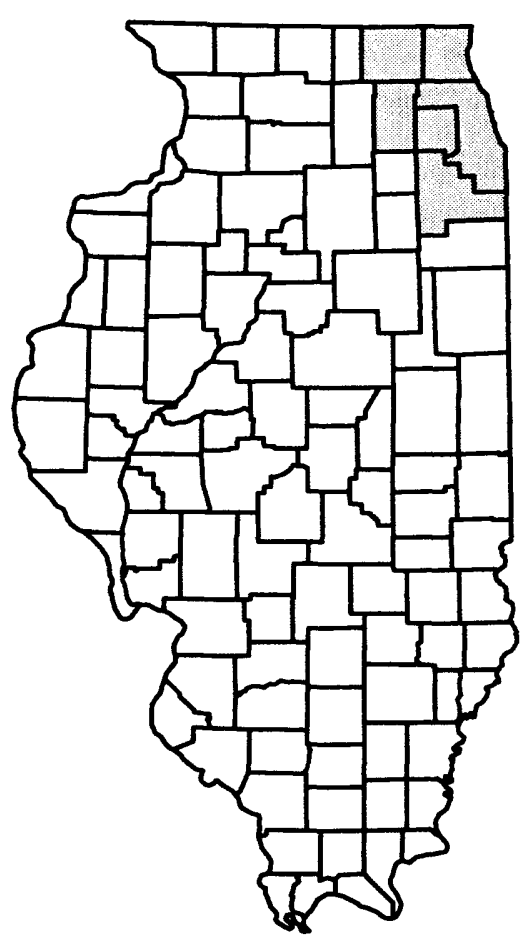

PROBLEM: Wetlands and other land cover in the six-county Chicago metropolitan area in northeastern Illinois are undergoing rapid changes in response to substantial economic growth and a rapidly growing suburban population. This area is the site of numerous surface-water, ground-water, and water-quality investigations by both the Illinois District of the USGS and several Federal, State, and local agencies. Most current wetlands and other land-cover digital data are outdated and of relatively poor spatial resolution. A critical need exists to update the digital land cover of northeastern Illinois at an improved spatial resolution in a format compatible with the appropriate geographic information system (GIS). This need is especially critical with respect to the wetlands of northeastern Illinois.

OBJECTIVES: (1) Create an updated digital data base of wetlands and other selected land-cover features of the six-county northeastern Illinois area at an improved resolution of approximately 0.22 acre per pixel (picture element). (2) Interface the updated landcover digital data base with a GIS that is compatible with the input requirements of District and (or) cooperator computer systems and hydrologic modeling programs.

APPROACH: (1) Merge Side-Looking Airborne Radar (SLAR) imagery with satellite-based Thematic Mapper (TM) imagery. (2) Classify the merged imagery with two techniques: (a) guided clustering and then (b) neural-network analysis. Assess accuracy of classification. (3) Convert the classified raster-based imagery to a vector format and load to a GIS. The project will be executed in two distinct phases. The first phase will involve the guided clustering analysis. The second phase will involve the neural-network analysis.

SUMMARY OF RESULTS: Digital analyses for phase one and phase two are complete. The report for the second phase of the project, documenting the artificial neural-network analyses, is under preparation for submission to colleague review.

PLANS: Perform accuracy assessment on phase one results; modify and reiterate analytical procedures as needed. Complete simulations and interpret results for phase two. Complete planned report.

\section{PLANNED REPORT:}

Sensitivity of an artificial neural network TM image classifier to selected architectures and training strategies 


\section{IL096 HYDROGEOLOGY AND CONTAMINANT ASSESSMENT IN THE SOUTHEASTERN CHICAGO AREA}

COOPERATOR:

U.S. Environmental Protection

Agency, Region V

LOCATION:

Southeastern Chicago Area

PROJECT CHIEF:

Robert T. Kay

De Kalb

PERIOD OF PROJECT:

September 1991 through

September 1995

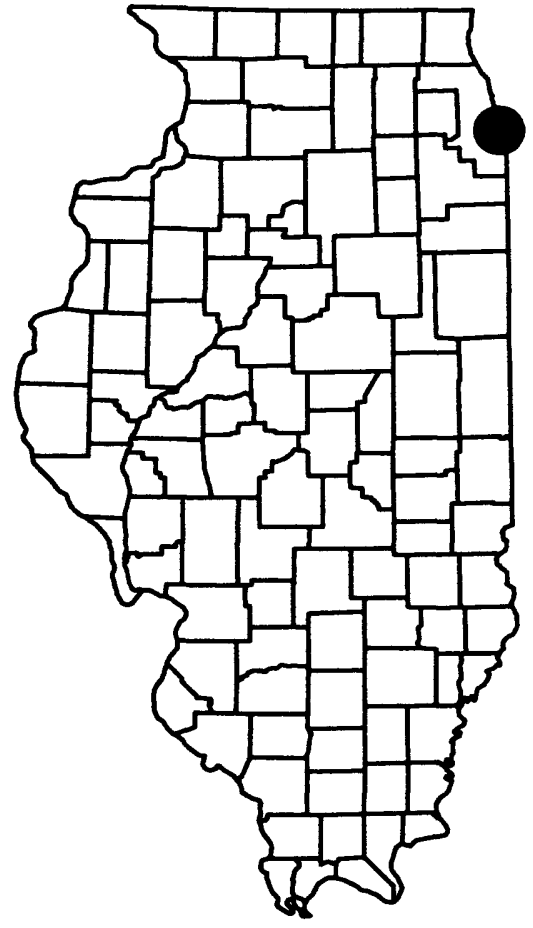

PROBLEM: The U.S. Environmental Protection Agency, Region V, has requested that the USGS, Illinois District, perform an investigation designed to define the hydrogeologic and water-quality conditions in the southeastern Chicago area. This area has significant surface-water and ground-water contamination, which presents a significant potential hazard.

OBJECTIVES: Characterize the hydrology of the surface-water and shallow ground-water system in the area of southeast Chicago. Characterize aquifer properties and water quality in the area. Identify the nature and extent of a potential non-aqueous-phase liquid layer, if present, underlying the study area.

APPROACH: Perform one or more synoptic water-level surveys in the area. Perform drilling, hydraulic testing, and water-quality sampling to determine the type of contamination present in the study area. Collect land-use, lithologic, and water-quality data to determine the location and extent of fill deposits and their affect on ground-water quality.

SUMMARY OF RESULTS: Completed water-quality sampling in southeastern Chicago and northwestern Indiana. Ten monitoring wells were installed in areas of limited data to support this effort. Organic compounds, especially semivolatile organics, are present in much of the area. These compounds are often associated with areas of slag deposition. The annotated outline for the report describing the results of the fill characterization has been approved.

PLANS: Drill additional wells to support the fill study. Collect water-quality samples in selected wells. Compile and analyze fill data. Publish water-level report. Submit water-quality report for technical review. Write draft of fill report.

\section{PLANNED REPORTS:}

Results of ground-water-quality sampling in northwestern Indiana and the Lake Calumet area of southeastern Chicago

Characterization and effect of ground-water quality of fill deposits in northwestern Indiana and the Lake Calumet area of southeastern Chicago

\section{REPORT IN PROCESS:}

Ground-water levels and directions of flow, and presence of light nonaqueous-phase liquids in ground water in northwestern Indiana and the Lake Calumet area of northeastern Illinois 


\section{IL097 SEDIMENTATION OF THE KANKAKEE RIVER}

COOPERATOR:

Kankakee Soil and Water

Conservation District

LOCATION:

Kankakee River Basin (northeastern Illinois and northwestern Indiana)

\section{PROJECT CHIEF:}

Richard H. Coupe, Jr.

Urbana

\section{PERIOD OF PROJECT:}

May 1992 through September 1996

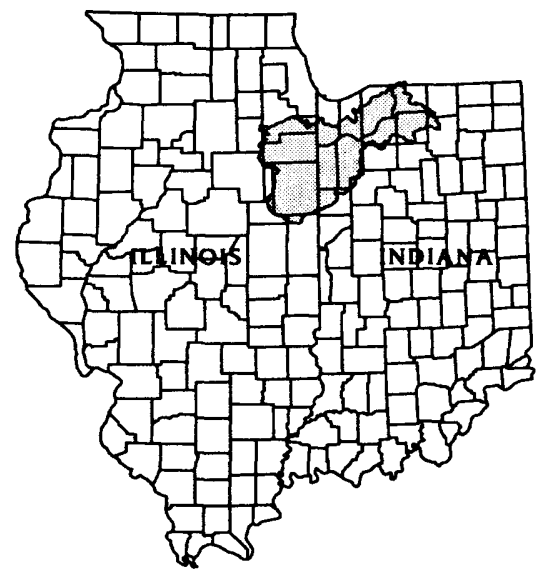

PROBLEM: Sedimentation in the Kankakee River in Illinois has been a major concern to Illinois residents for many years. Previous studies (Bhowmik and Bogner, 1981; Gross and Berg, 1981) concluded that extensive drainage of the wetlands and channelization of the Kankakee River did cause increased sedimentation, but, by the early 1950 's, the river had reached equilibrium and further sedimentation was not observed. However, during the years since the State studies were completed, Illinois residents utilizing the river continue to be concerned about whether sedimentation rates have continued to increase.

OBJECTIVES: (1) Determine the long-term sedimentation rate in the flood plain and compare rates in channelized and natural reaches of the river, (2) determine changes in channel geometry and volume over the past 30 years from the dam at Kankakee to the State line, and (3) determine a suspended-sediment budget for the central portion of the Kankakee River Basin.

APPROACH: The study will build on and extend the previous work of the State Surveys and the Illinois Department of Transportation, Division of Water Resources. Long-term flood-plain sedimentation rates will be estimated by applying dendrogeomorphic techniques. The rate of sedimentation in the channel will be determined by measuring changes in channel geometry for selected reaches of the river over the past 30 years. A long-term sediment monitoring program will be initiated to calculate a sediment budget.

SUMMARY OF RESULTS: Draft report on the dendrogeomorphic study has been completed and is ready for colleague review. Sediment data have been collected at six stations in the Kankakee River Basin.

PLANS: Publish report on dendrogeomorphic study. Continue operation of six sediment-monitoring stations. Survey approximately 70 channel cross sections to determine changes in channel geometry.

\section{PLANNED REPORTS:}

Evaluation of channel geometry investigation on the Kankakee River near Momence, Illinois

Suspended-sediment data collected on the Kankakee River, Illinois, 1992-95

\section{REPORT IN PROCESS:}

Dendrogeomorphic estimate of changes in sedimentation rate along the Kankakee River near Momence, Illinois 


\section{IL098 TRANSPORT AND FATE OF VOLATILE ORGANIC COMPOUNDS DURING LANDFILL-GAS MIGRATION THROUGH THE SUBSURFACE ENVIRONMENT}

COOPERATOR:

Wisconsin Department of Natural Resources

LOCATION: Wisconsin

PROJECT CHIEF:

Robert T. Kay

De Kalb

PERIOD OF PROJECT:

October 1991 through September 1993

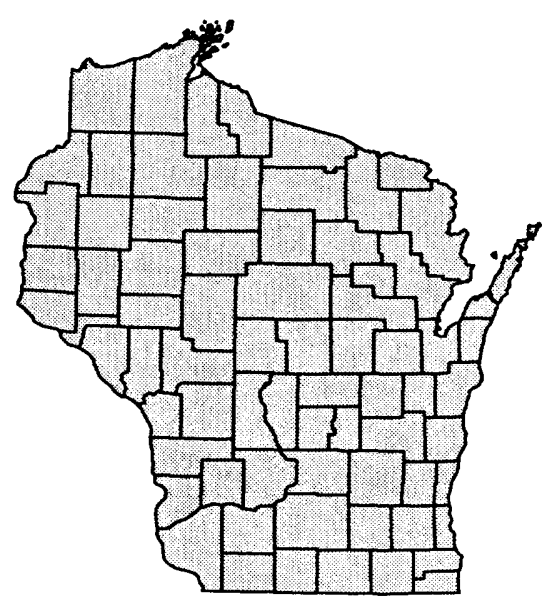

PROBLEM: The migration of carbon dioxide, methane, and volatile organic compounds (VOC's) from sanitary landfills can pose a serious health risk both to residents adjacent to the landfill site and to those who make use of ground water exposed to these compounds. At this time, little is known about the processes that control the concentration, distribution, and fate of these compounds.

OBJECTIVES: (1) Determine the effects of the interaction between landfill gases, microbiota, soil, soil water, condensate, and ground water on the concentration of contaminants, and (2) determine the effects of leachate migration on the migration of the different compounds.

APPROACH: To meet the objectives of this study, the general approach will consist of (1) characterization of the geological properties of the soil material; (2) identification of the type, concentration, and distribution of selected chemical constituents in ground water, soil water, soil particles, land leachate, condensate, and soil gas; (3) characterization of the microbiological communities in the unsaturated zone; and (4) development of a quantitative model of the system, involving contaminant migration in both the liquid and gaseous phases.

SUMMARY OF RESULTS: (1) Continued monitoring for water and landfill-gas quality at landfill for part of the year. (2) Completed the establishment of gas-sampling protocols with the Illinois Hazardous Waste Research Institute. (3) Compiled all data collected and made available to cooperator and interested parties. (4) Stopped monitoring at end of year and removed all equipment.

PLANS: Project terminated September 30, 1993. Access to landfill was denied because of possible litigation. 


\section{IL099 HYDRAULIC MODEL VERIFICATION AND DOCUMENTATION FOR UNSTEADY FLOW}

\section{COOPERATORS:}

\author{
Illinois Department of \\ Transportation, Division of \\ Water Resources \\ Du Page County, Department of \\ Environmental Concerns
}

\section{LOCATION:}

Northeastern Illinois

\section{PROJECT CHIEF:}

\author{
Audrey L. Ishii
}

Urbana

\section{PERIOD OF PROJECT:}

June 1992 through September 1995

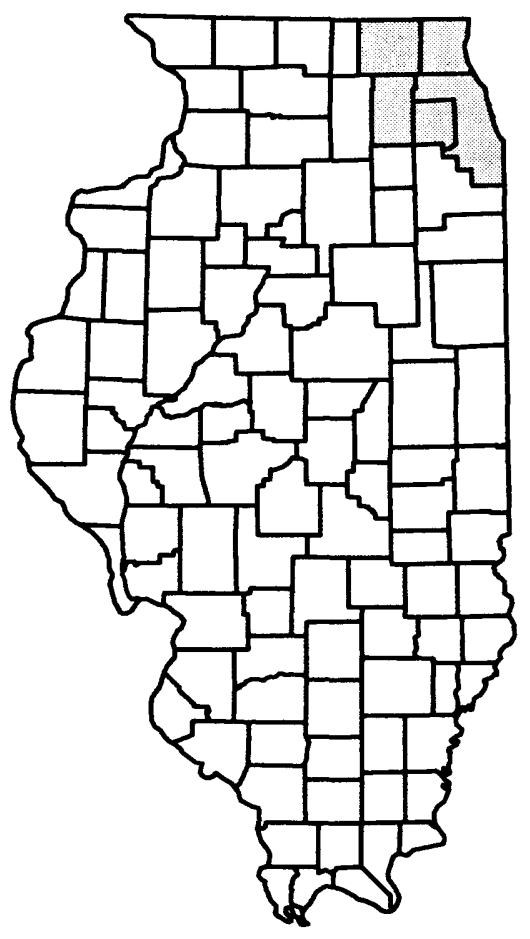

PROBLEM: Steady-flow model computations may be inadequate for flood-plain delineation in many locations, particularly where river reaches have low or flat slopes and extensive flood-plain flow and storage. Most unsteady-flow models are restricted from application at internal boundaries, such as bridges, dams, weirs, and culverts. A verified and documented unsteady-flow model that includes internal boundaries in its overall solution scheme is needed for a wide variety of applications.

OBJECTIVE: To verify and document the one-dimensional, unsteady flow, Full EQuations (FEQ) hydraulic routing model and its companion Full EQuations UTiLity program (FEQUTL). The verification will be accomplished with a well-documented data set of measured flows and elevations under a variety of unsteady-flow conditions. The documentation will include a detailed description of the governing equations of the model, solution procedures, input and output requirements, and a guide to model applications.

APPROACH: The study has four main tasks: (1) data collection and documentation, (2) model calibration and verification, (3) model documentation, and (4) the preparation, testing, and revision of a user's guide. For the first task, discharge and stage data will be collected with continuous recorders on a small stream subject to overbank and backwater flow. Measurement of flows in the overbank and culvert sections will be made during floods, and elevations upstream and downstream from the culvert will be recorded. This data set and the dye, stage, and discharge data collected during a period of unsteady flow on the Fox River for a previous project (IL091) (Balding, 1994, p. 40) will be documented in a report and used to verify the model. For the second task, models will be prepared or obtained for the Fox River, the small stream, and a sewer pipe utilized under laboratory conditions for which unsteady-flow data are available. The models will be calibrated with data independent of the verification data sets. The induced or natural floodwaves will be routed through the models and the differences between the simulated and measured flows and elevations compared. For the Fox River model, the simulated flow field will be input to a transport model and the simulated dye concentrations compared to the measured dye concentrations. The model documentation (task 3) will result in a report documenting (a) river network visualization and schematization, flow-governing equations, and solution procedures used in FEQ; (b) governing equations and tabular representations used in the well-established features of FEQUTL; and (c) input formats for FEQ and FEQUTL. The report will be written by a contractor according to detailed specifications provided by the USGS. A detailed annotated outline will be prepared by the Illinois District and USGS specialists at all stages of development. The final task (task 4) is to provide a user's guide that describes a specific, typical application of the model in sufficient detail to provide guidance to firsttime users and a ready reference of key features for experienced users. This guide will be tested on first-time users within the Illinois District and revised prior to publication. 
SUMMARY OF RESULTS: A report documenting the dye, stage, and discharge data collected during the unsteady-flow synoptic on the Fox River in November 1990 has been approved. The verification study for the FEQ model of the Fox River has been completed and the report is in review. The documentation report for the FEQ model has been drafted and is being readied for review. Flood measurements have been made at a culvert and overbank area on Spring Brook in Du Page County. The model has been calibrated for the reach, and the results are being checked. The effect of various boundary conditions were studied and a paper on the subject was presented at the International Association for Hydraulic Research XXV Congress. A presentation of the dyetransport modeling results was made at the 1993 Fall Meeting of the American Geophysical Union.

PLANS: The documentation reports will be reviewed and readied for approval. An applications guide will be drafted and tested. The verification report will be submitted for approval. The results of the culvert and overbank modeling study will be presented as a conference paper.

\section{PLANNED REPORTS:}

Implementation and verification of a one-dimensional, unsteady-flow model for Spring Brook near Warrenville, Illinois

Full Equations (FEQ) Model for the solution of the full, dynamic equations of motion for one-dimensional, unsteady flow in open channels and through control structures

\section{REPORTS IN PROCESS:}

Data-collection methods and data summary for verification of a one-dimensional, unsteady-flow model of the Fox River in northeastern Illinois, October-November 1990

Verification of a one-dimensional, unsteady-flow model for the Fox River in Illinois

\section{PUBLISHED PAPER:}

Effect of boundary condition data selection on unsteadyflow model calibration, by A.L. Ishii and J.E. Wilder, in Proceedings of XXV Congress of International Association for Hydraulic Research, special lectures, technical session A, flood and drought, v. 1, August 30September 3, 1993, Tokyo, Japan, p. 193-200. 


\section{IL100 SOUTHEAST ROCKFORD SITE CHARACTERIZATION}

COOPERATOR:

U.S. Environmental Protection

Agency, Region V

LOCATION:

Southeast Rockford

PROJECT CHIEF:

Robert T. Kay

De Kalb

PERIOD OF PROJECT:

October 1992 through September 1994

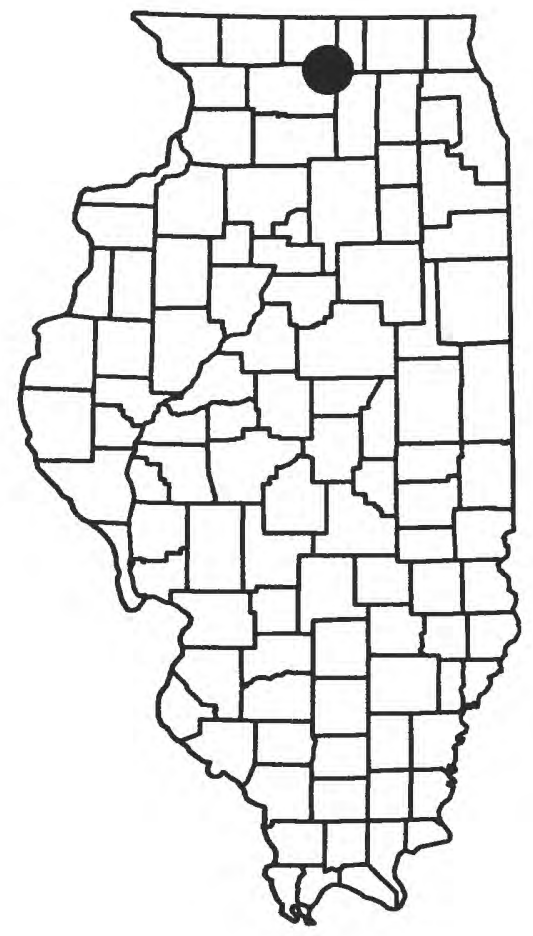

PROBLEM: The southeast Rockford area has experienced significant ground-water-quality degradation because of concentrated industrial and waste-disposal activities. The maximum depth of contamination and the potential for contamination of the deep dolomite and sandstone aquifers pumped for water supply in the area must be evaluated.

OBJECTIVES: Determine the types and concentrations of volatile organic compounds (VOC's) in the dolomite aquifer, the vertical extent of ground-water contamination, and the factors affecting the migration of VOC's in the aquifer.

APPROACH: Identify stratigraphy, fracture orientation, and ground-water movement within three boreholes. Collect and analyze ground-water samples from monitoring wells for VOC's.

SUMMARY OF RESULTS: VOC's in the dolomite aquifer are not migrating because of pumping in the underlying sandstone aquifer. A report describing the results of the study is in review. Work continues in the review of technical documents and reports submitted to the U.S. Environmental Protection Agency, Region V, on the hydrology and ground-water-quality degradation of the southeastern Rockford area.

PLANS: Complete the review of technical documents and reports submitted to the USEPA. Finalize all ground-water level maps and analyses of ground-water samples for VOC's. Respond to all review comments and publish the report.

\section{REPORT IN PROCESS:}

Geohydrology and ground-water quality in the vicinity of a ground-water contamination site in Rockford, Illinois

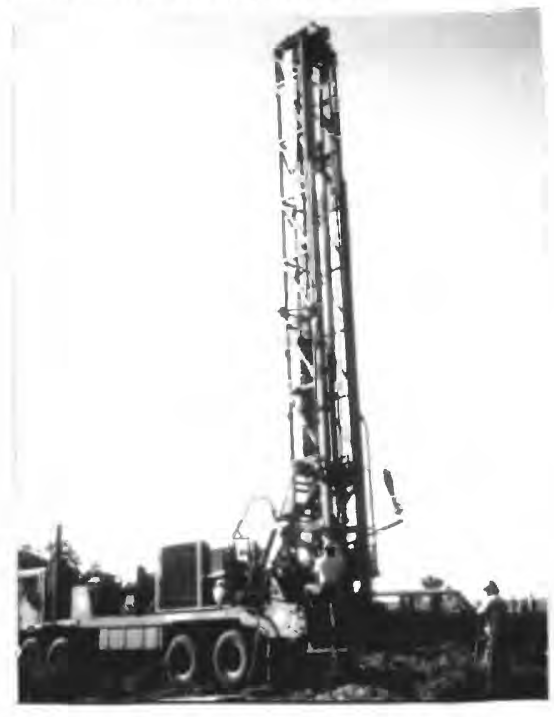

Drilling a test hole to obtain subsurface hydrologic and geologic information 


\section{IL101 CRAB ORCHARD OVERSIGHT ACTIVITIES}

COOPERATOR:

U.S. Fish and Wildlife Service

LOCATION:

Crab Orchard National Wildlife Refuge

\section{PROJECT CHIEF:}

Charles F. Avery

Urbana

PERIOD OF PROJECT:

October 1992 through September 1996

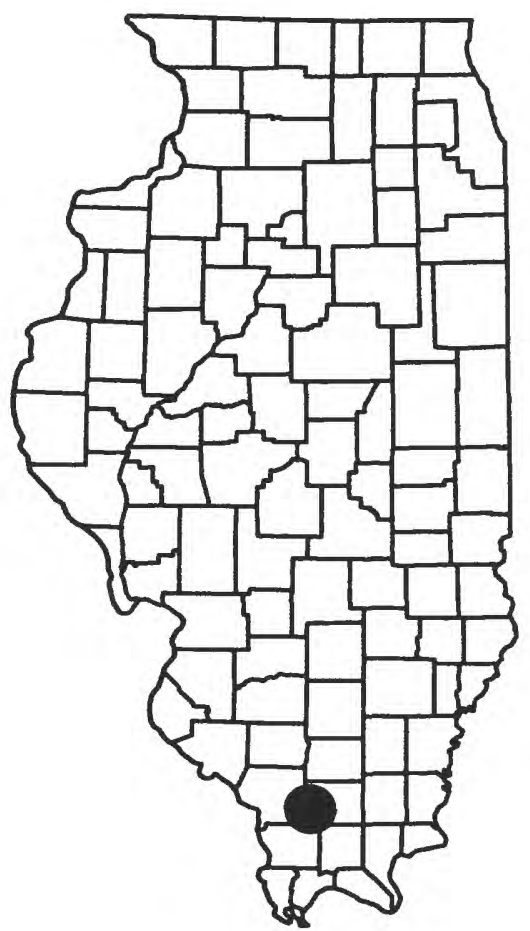

Problem: The Crab Orchard National Wildlife Refuge, constituting an area of 43,000 acres, is located about 5 miles west of Marion, Williamson County, Illinois. The Illinois Ordnance Plant operated within the present refuge, in the 1940's, as a manufacturing and loading site for high explosives and other components. An ammonium nitrate fertilizer plant also operated at the site. A remedial investigation and feasibility study, completed in 1989 , defined areas of contamination in the soil and shallow ground water at various sites. The U.S. Environmental Protection Agency grouped sites with similar characteristics into four operable units (metals areas, PCB's areas, munitions areas, and miscellaneous areas). The areal and vertical extent of contamination need further definition in order to evaluate the potential impacts to the subsurface environment.

OBJECTIVES: Perform oversight activities of work performed by the Department of the Army at the Explosives/Munitions Manufacturing Areas Operable Unit. Insure that this remedial investigation/feasibility study, performed by the Army, adequately characterizes the nature and extent of contamination as related to the hydrology of the study area. Assist the Fish and Wildlife Service in data-base-management activities.

APPROACH: Apply USGS methodology to evaluate site conditions.

SUMMARY OF RESULTS: Reviewed remedial investigations/feasibility study documents for the Explosives/Munitions Operable Unit.

PLANS: Review documents for other operable units. Assist the Fish and Wildife Service in developing and maintaining a data-basemanagement system and applying geographic information system technology for data analysis and review. 


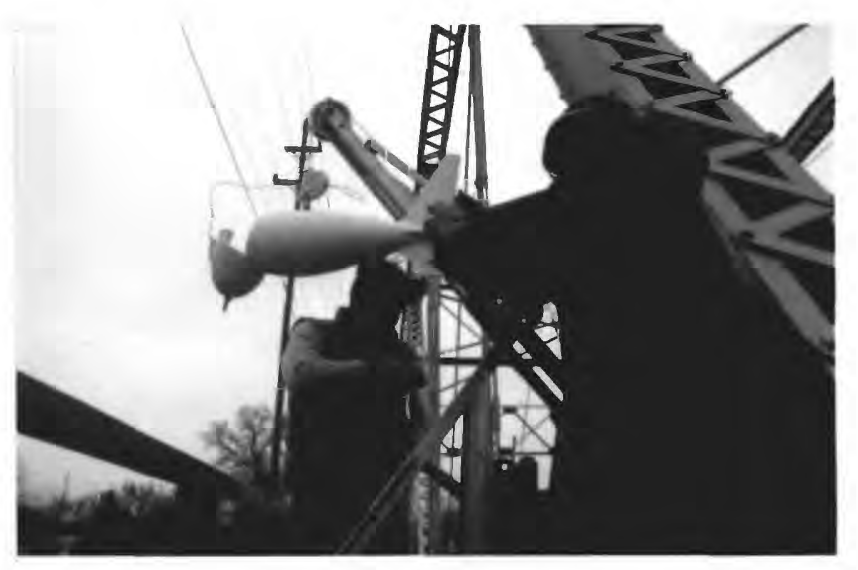

Preparing to collect a suspended-sediment sample from a stream

\section{PUBLICATIONS}

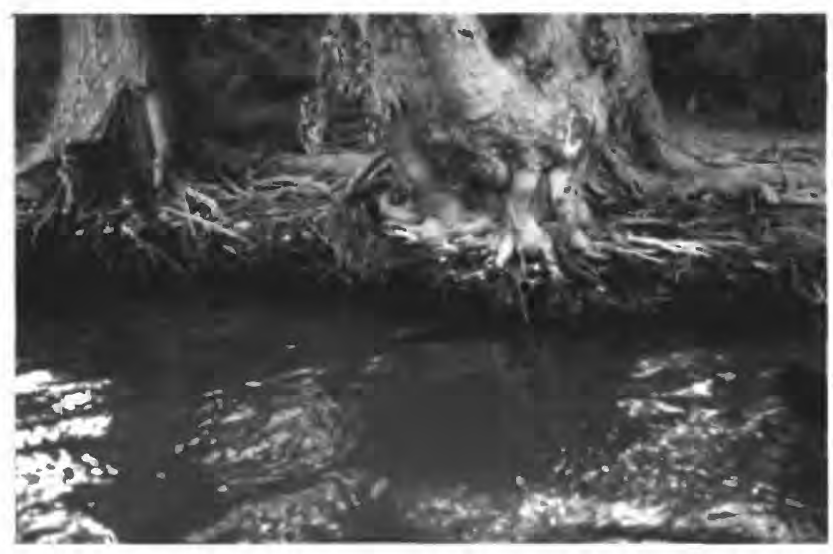

Trees help to stabilize stream banks, but the erosive power of flowing water can take its toll 


\section{PUBLICATIONS}

The USGS announces all its publications in a monthly catalog "New Publications of the U.S. Geological Survey." Free subscriptions to this list are available from U.S. Geological Survey, 582 National Center, Reston, VA 22092. All publications are for sale unless specifically stated otherwise. Prepayment is required and information on price and availability should be obtained before placing an order. The "U.S. Geological Survey Yearbook" provides a comprehensive description of the Federal Government's largest earth-science agency. Copies of the yearbook may be purchased at the address where professional papers are sold (see below).

\section{Water-Resources Information}

A monthly summary of the national water situation is presented in "National Water Conditions." It is available free, on request, from the Hydrologic Information Unit, U.S. Geological Survey, 419 National Center, Reston, VA 22092.

Beginning with the 1971 water year, a new publication series entitled "U.S. Geological Survey Water-Data Reports," combined for each State under one cover streamflow data, water-quality data for surface and ground water, and ground-water-level data. For Illinois, the title is "Water Resources Data for Illinois-Water Year 19XX: U.S. Geological Survey Water-Data Report IL-XX-1 and IL-XX-2" (XX represents water year published). Prior to the 1971 water year, records of streamflow, quality of water, and ground-water levels were published in U.S. Geological Survey Water-Supply Papers as explained below.

\section{Streamflow Records}

Records of daily flows of streams prior to 1971 were published in the Water-Supply Paper series "Surface-Water Supply of the United States," which were released in numbered parts as determined by natural drainage basins; until 1961 this was an annual series. Monthly and yearly summaries of these data were then compiled in two reports: "Compilation of Records of Surface Waters of the United States through September 1950" and "Compilation of Records of Surface Waters of the United States, October 1950 to
September 1960." For the period 1961-70, 5-year compilations were published; data for Illinois are published in Parts 3, 4, and 5 of these reports.

\section{Water-Quality Records}

Data on quality of surface water, prior to 1971 , were published annually in the Water-Supply Paper series "Quality of Surface Waters of the United States," which also was released in numbered parts as determined by natural drainage basins. Data for Illinois are in Parts 3, 4, and 5 of that series.

\section{Ground-Water Records}

Ground-water levels and artesian pressures in observation wells prior to 1975 were reported by geographic areas in a 5-year Water-Supply Paper series. Data for Illinois are in "Ground-Water Levels in the United States, North-Central States."

\section{PUBLICATIONS PERTINENT TO ILLINOIS}

The reports listed below represent selected references prepared by the USGS in cooperation with other agencies. The list contains reports that contribute to the understanding of the hydrology of the water resources in Illinois.

\section{Professional Papers}

Professional Papers are comprehensive formal reports of significant and lasting scientific interest and include results of resource studies and of geologic, hydrologic, or topographic investigations. Professional Papers are sold by the U.S. Geological Survey, Branch of Distribution, Box 25286, MS 306, Denver Federal Center, Denver, CO 80225 (phone 303-2367477).

P 448-H Low-flow characteristics of streams in the Mississippi embayment in Tennessee, Kentucky, and Illinois, by P.R. Speer, W.J. Perry, J.A. McCabe, O.G. Lara, and others, with a section on Quality of the water by H.G. Jeffery. 1965.

P 813-A Summary appraisals of the Nation's ground-water resources-Ohio Region, by R.M. Bloyd, Jr. 1974.

P 813-B Summary appraisals of the Nation's ground-water resources-Upper Mississippi Region, by R.M. Bloyd, Jr. 1975. 
P 813-J Summary appraisals of the Nation's ground-water resources-Great Lakes Region, by W.G. Weist, Jr. 1977.

P 1467 Floods of March 1982 in Indiana, Ohio, Michigan, and Illinois, by D.R. Glatfelter, U.S. Geological Survey; and E.H. Chin, National Weather Service, NOAA. 1988.

\section{Water-Supply Papers}

Water-Supply Papers are formal reports dealing with all aspects of hydrology, including quality, recoverability, and use of water resources; statistical reports on streamflow, floods, ground-water levels, and water quality; and collections of short papers on related topics. Water-Supply Papers are sold by the U.S. Geological Survey, Branch of Distribution, Box 25286, MS 306, Denver Federal Center, Denver, CO 80225 (phone 303-236-7477).

W 1370-B Floods of October 1954 in the Chicago area, Illinois and Indiana, by W.S. Daniels and M.D. Hale. 1958.

W 1669-O Ground-water conditions at Argonne National Laboratory, Illinois, $1948-60$, by D.B. Knowles, W.J. Drescher, and E.F. LeRoux. 1963.

W 2002 Water in urban planning, Salt Creek Basin, Illinois, by A.M. Spieker. 1970.

W 2005 Model hydrographs, by W.D. Mitchell. 1972.

W 2078 Some chemical characteristics of mine drainage in Illinois, by L.G. Toler. 1982.

W 2226 Low-level radioactive-waste burial at the Palos Forest Preserve, Illinois: Geology and hydrology of the glacial drift, as related to the migration of tritium, by J.C. Olimpio. 1984.

W 2250 National Water Summary 1983-Hydrologic events and issues, by U.S. Geological Survey. 1984.

W 2262 A system for measuring surface runoff and collecting sediment samples from small areas, by J.R. Gray and M.P. deVries, in Meyer E.L., ed., Selected papers in the hydrologic sciences. 1984.

W 2269 Traveltime and longitudinal dispersion in Illinois streams, by J.B. Graf. 1986.

W 2275 National Water Summary 1984-Hydrologic events, selected water-quality trends, and ground-water resources, by U.S. Geological Survey. 1985.

W 2300 National Water Summary 1985-Hydrologic events and surface-water resources, by U.S. Geological Survey. 1986.
W 2301

Relations between quality of urban runoff and quality of Lake Ellyn at Glen Ellyn, Illinois, by R.G. Striegl and E.A. Cowan. 1987.

W 2325 National Water Summary 1986-Hydrologic events and ground-water quality, by U.S. Geological Survey. 1988.

W 2327

Evapotranspiration and microclimate at a low-level radioactive-waste disposal site in northwestern Illinois, by R.W. Healy, M.P. deVries, and A.M. Sturrock, Jr. 1989.

W 2333 Tritium migration from a low-level radioactive-waste disposal site near Chicago, Illinois, by J.R. Nicholas and R.W. Healy. 1988.

W 2350 National Water Summary 1987-Hydrologic events and water supply and use, by U.S. Geological Survey. 1990.

W 2362 Floods of December 1982 to May 1983 in the central and southern Mississippi River and the Gulf of Mexico Basins, by R.B. Stone and R.H. Bingham. 1991.

W 2367 Results of hydrologic research at a low-level radioactive-waste disposal site near Sheffield, Illinois, by B.J. Ryan. 1991.

W 2375 National Water Summary 1988-89-Hydrologic events and floods and droughts, by U.S. Geological Survey. 1991.

W 2386 Water and tritium movement through the unsaturated zone at a low-level radioactive-waste disposal site near Sheffield, Illinois, 1981-85, by P.C. Mills and R.W. Healy. 1993.

W 2390 Effects of low-level radioactive-waste disposal on water chemistry in the unsaturated zone at a site near Sheffield, Illinois, 1982-1984, by C.A. Peters, R.G. Striegl, P.C. Mills, and R.W. Healy. 1992.

W 2398 Water movement and water chemistry in the unsaturated zone at a low-level radioactive-waste disposal site near Sheffield, Illinois, 1986-87, by P.C. Mills. 1993.

W 2400 National Water Summary 1990-91 - Hydrologic events and stream water quality, by U.S. Geological Survey. 1993.

\section{Circulars}

Circulars contain technical or nontechnical information of popular interest including timely administrative or scientific information. Circulars may be ordered, free of charge, from the U.S. Geological Survey, Branch of Distribution, Box 25286, MS 306, Denver Federal Center, Denver, CO 80225 (phone 303-236-7477). 
C 216 Water resources of the St. Louis area, Missouri and Illinois, by J.R. Searcy, R.C. Baker, and W.H. Durum. 1952.

C 601-C Flood hazard mapping in metropolitan Chicago, by J.R. Sheaffer, D.W. Ellis, and A.M. Spieker. 1970.

C 900 Guide to obtaining USGS information, by Kurt Dodd, H.K. Fuller, and P.F. Clarke. 1989.

C 953 Proceedings of the advanced seminar on sedimentation, August 15-19, 1983, Denver, Colorado, edited by G.D. Glysson. 1987.

Erosion and landform modification at a low-level radioactive-waste disposal facility near Sheffield, Illinois, by J.R. Gray.

Measurement of bedload discharge in nine Illinois streams with the Helley-Smith sampler, by J.B. Graf.

C 1004 Estimated use of water in the United States in 1985, by W.B. Solley, C.F. Merk, and R.R. Pierce. 1988.

C 1036 Safe disposal of radionuclides in low-level radioactive-waste repository sites; Low-level radioactive-waste disposal workshop, U.S. Geological Survey, July 11-16, 1987, Big Bear Lake, California, proceedings edited by M.S. Bedinger and P.R. Stevens. 1990.

Surface hydrology at the low-level radioactivewaste repository site near Sheffield, Illinois, by J.R. Gray.

Results of some geohydrologic studies at the lowlevel radioactive-waste repository site near Sheffield, Illinois, by R.W. Healy.

C 1120-A Flood discharges in the upper Mississippi River Basin, 1993, by Charles Parrett, N.B. Melcher, and R.W. James, Jr. 1993.
C 1120-B Precipitation in the upper Mississippi River Basin, January 1 through July 31, 1993, by K.L. Wahl, K.C. Vining, and G.J. Wiche. 1993.

C1120-C Occurrence and transport of agricultural chemicals in the Mississippi River Basin, July through August 1993, by D.A. Goolsby, W.A. Battaglin, and E.M. Thurman. 1993.

\section{Hydrologic Investigations Atlases}

Hydrologic Investigations Atlases may contain a wide range of hydrologic and hydrogeologic data of regional and national interest, such as streamflow, ground water, water quality, and extent of flooding. Hydrologic Investigations Atlases and other maps are sold by the U.S. Geological Survey, Map Distribution, Box 25286, Bldg. 810, Denver Federal Center, Denver, CO 80225 (phone 303-236-7477). The Hydrologic Investigations Atlases that pertain to stream basins in Illinois are as follows:

HA-39. Floods in the Little Calumet River Basin near Chicago Heights, [northeastern] Illinois. 1960.

HA-449. Floods on Loop Creek and Richland Creek near Belleville, [southwestern] Illinois, by J.D. Camp. 1972.

The Hydrologic Investigations Atlases (HA) listed below are all flood maps for quadrangles in Illinois. The information in the table can be used, as shown in the following example, to construct the full bibliographic reference. The example reference is as follows:

HA-67 Floods in Arlington Heights quadrangle, [northeastern] Illinois, by D.W. Ellis, H.E. Allen, and A.W. Noehre. 1963.

\begin{aligned} $\begin{array}{r}\text { HA } \\ \text { number }\end{array} & \multicolumn{1}{c}{$ Quadrangle } \\ 67 & Arlington Heights \\ 68 & Elmhurst \\ 69 & Highland Park \\ 70 & Aurora North \\ 71 & Wheeling \\ & \\ 85 & Park Ridge \\ 86 & Hinsdale \\ 87 & Palatine \\ 88 & Libertyville \\ 89 & Joliet \\ & \\ 90 & Harvey \\ 142 & Geneva \\ 143 & Lombard \\ 144 & Wadsworth \\ 145 & Palos Park \end{aligned}

\begin{tabular}{lc}
\multicolumn{1}{c}{ Authors } & $\underline{\text { Date }}$ \\
& \\
Ellis, D.W., Allen, H.E., and Noehre, A.W. & 1963 \\
Ellis, D.W., Allen, H.E., and Noehre, A.W. & 1963 \\
Ellis, D.W., Allen, H.E., and Noehre, A.W. & 1963 \\
Ellis, D.W., Allen, H.E., and Noehre, A.W. & 1963 \\
Ellis, D.W., Allen, H.E., and Noehre, A.W. & 1963 \\
& \\
Ellis, D.W., Allen, H.E., and Noehre, A.W. & 1963 \\
Ellis, D.W., Allen, H.E., and Noehre, A.W. & 1964 \\
Allen, H.E., Ellis, D.W., and Long, D.E. & 1964 \\
Noehre, A.W., Ellis, D.W., and Long, D.E., & 1964 \\
Allen, H.E., and Wyerman, T.A. & 1964 \\
& \\
Allen, H.E., and May, V.J. & 1964 \\
Noehre, A.W., and Walter, G.L. & 1965 \\
Allen, H.E., and May, V.J. & 1964 \\
Noehre, A.W. & 1964 \\
Noehre, A.W., and Mycyk, R.T. & 1966
\end{tabular}


HA

number

\begin{tabular}{|c|c|}
\hline 146 & Romeoville \\
\hline 147 & Elgin \\
\hline 148 & Wheaton \\
\hline 149 & Sag Bridge \\
\hline 150 & Barrington \\
\hline 151 & Fox Lake \\
\hline 152 & Tinley Park \\
\hline 153 & Blue Island \\
\hline 154 & Naperville \\
\hline 202 & West Chicago \\
\hline 203 & Streamwood \\
\hline 204 & Mokena \\
\hline 205 & Lake Calumet \\
\hline 206 & River Forest \\
\hline 207 & Wauconda \\
\hline 208 & Lake Zurich \\
\hline 209 & Steger \\
\hline 210 & Normantown \\
\hline 211 & Manhattan \\
\hline 226 & Antioch \\
\hline 227 & Sugar Grove \\
\hline 228 & Plainfield \\
\hline 229 & Elburn \\
\hline 230 & Grayslake \\
\hline 231 & Frankfort \\
\hline 232 & Pingree Grove \\
\hline 233 & Zion \\
\hline 234 & Waukegan \\
\hline 251 & Peotone \\
\hline 252 & Berwyn \\
\hline 253 & Crystal Lake \\
\hline 254 & Elwood \\
\hline 255 & McHenry \\
\hline 256 & Woodstock \\
\hline 257 & Beecher West \\
\hline 301 & Dyer \\
\hline 302 & Beecher East \\
\hline 303 & Richmond \\
\hline 304 & Wilton Center \\
\hline 305 & Symerton \\
\hline 306 & Wilmington \\
\hline 361 & Huntley \\
\hline 362 & Channahon \\
\hline 363 & Hebron \\
\hline 458 & Maple Park \\
\hline
\end{tabular}

Noehre, A.W., and Walter, G.L.

May, V.J., and Allen, H.E.

Allen, H.E.

1966

Allen, H.E., and May, V.J.

1965

Allen, H.E., and May, V.J.

1965

May, V.J., and Allen, H.E.

1965

Noehre, A.W.

1965

Allen, H.E.

May, V.J.

1966

Allen, H.E.

1966

1966

Noehre, A.W., and Mycyk, R.T. 1966

Allen, H.E.

1966

May, V.J.

1966

Allen, H.E., and Mycyk, R.T.

1966

Noehre, A.W., and Walter, G.L.

1966

Allen, H.E.

1966

May, V.J., and Schafish, R.J. 1966

Allen, H.E.

1966

May, V.J., Noehre, A.W., and Walter, G.L.

1967

Mycyk, R.T.

1967

Allen, H.E.

1967

May, V.J., and Mycyk, R.T.

1967

Mycyk, R.T., and May, V.J.

1967

Allen, H.E.

1967

Noehre, A.W., and Walter, G.L. 1967

May, V.J., and Mycyk, R.T. 1967

Allen, H.E., and Mycyk, R.T. 1967

Mycyk, R.T., and Walter, G.L. 1968

Allen, H.E. $\quad 1968$

Allen, H.E. $\quad 1968$

Allen, H.E. $\quad 1968$

Allen, H.E., and Noehre, A.W. 1969

Mycyk, R.T., and Walter, G.L. 1969

Allen, H.E., and Noehre, A.W. 1969

Allen, H.E., Noehre, A.W., and Hauth, L.D. 1970

Allen, H.E., and Noehre, A.W. 1971

Walter, G.L., and Mycyk, R.T. 1971

Allen, H.E., and Noehre, A.W. 1971

Allen, H.E., and Grant, R.S. 1971

Mycyk, R.T., and Walter, G.L. 1972 


\begin{tabular}{cllr}
$\begin{array}{c}\text { HA } \\
\text { number }\end{array}$ & \multicolumn{1}{c}{ Quadrangle } & \multicolumn{1}{c}{ Authors } & $\underline{\text { Date }}$ \\
459 & Hampshire & Mycyk, R.T., and Duerk, M.D. & 1972 \\
463 & Marengo South & Allen, H.E. & 1972 \\
464 & Riley & Mycyk, R.T., and Grant, R.S. & 1972 \\
472 & Big Rock & Mycyk, R.T., Walter, G.L., and McDonald, B.L. & 1973 \\
495 & Marengo North & Allen, H.E., and Noehre, A.W. & 1973 \\
& & & 1973 \\
496 & Harvard & Allen, H.E., and Noehre, A.W. & 1973 \\
497 & Garden Prairie & Mycyk, R.T., and Grant, R.S. & 1973 \\
498 & Capron & Grant, R.S., and Duerk, M.D. &
\end{tabular}

\section{Hydrologic-Unit Maps}

Hydrologic-Unit Maps have been developed for each State and depict the major hydrologic regions, subregions, accounting units, and cataloging units used for the collection and organization of hydrologic data. Hydrologic-Unit Maps and other maps are sold by the U.S. Geological Survey, Map Distribution, Box 25286, Bldg. 810, Denver Federal Center, Denver, CO 80225 (phone 303-236-7477).

U.S. Geological Survey, 1975, Hydrologic unit map of Illinois1974.

A companion publication describing hydrologic units nationwide titled, "Hydrologic Unit Maps" by P.R. Seaber, F.P. Kapinos, and G.L. Knapp, 1987, U.S. Geological Survey Water-Supply Paper 2294, is available from the same above mentioned source.

\section{Water-Resources Investigations Reports (WRI or WRIR)}

Water-Resources Investigations Reports contain hydrologic information, mainly of local interest. The reports are intended for quick release to the public in book or map format.

\section{WRINTIS}

The following reports may be ordered, free of charge, while supplies last, from the District Chief, U.S. Geological Survey, 102 E. Main Street, 4th Floor, Urbana, IL 61801 (phone 217-398-5353). The reports are sold either as microfiche or hard copy by the National Technical Information Service (NTIS), U.S. Department of Commerce, 5285 Port Royal Road, Springfield, VA 22161 (phone 703-487-4650); the NTIS ordering number is given in parentheses at the end of the citation.
WRI 13-75. Drainage areas for Illinois streams, by K.M. Ogata, 1975. (PB 246298/AS)

WRI 77-104. Frequency analysis of Illinois floods using observed and synthetic streamflow records, by G.W. Curtis, 1977. (PB 277350/AS)

WRI 77-117. Technique for estimating magnitude and frequency of floods in Illinois, by G.W. Curtis, 1977. (PB 277255/AS)

WRI 78-22, Chemical analyses of surface water in Illinois, 23, 24. 1958-74, Volume I, Des Plaines River Basin and Lake Michigan; Volume II, Illinois River Basin and Mississippi River tributaries north of Illinois River Basin; Volume III, Ohio River tributaries and Mississippi River tributaries south of Illinois River Basin, by R.W. Healy and L.G. Toler, 1978. Three-volume set (PB 282673/AS)

WRI 78-78. Water quality in the Sugar Creek Basin, Bloomington and Normal, Illinois, by B.J. Prugh, Jr., 1978. (PB 288359/AS)

WRI 79-23, Chemical analyses of surface water in Illinois, 24, 25. 1975-77, Volume I, Des Plaines River Basin and Lake Michigan; Volume II, Illinois River Basin and Mississippi River tributaries north of Illinois River Basin; Volume III, Ohio River tributaries and Mississippi River tributaries south of Illinois River Basin, by David Grason and R.W. Healy, 1979. Three-volume set (PB 299911/AS)

WRI 79-36. Effects of urbanization on the magnitude and frequency of floods in northeastern Illinois, by H.E. Allen, Jr. and R.M. Bejcek, 1979. (PB 299065/AS)

WRI 79-110. River mileages and drainage areas for Illinois streams-Volume 1, Illinois except Illinois River Basin, by R.W. Healy, 1979. (AD A082472)

WRI 79-111. River mileages and drainage areas for Illinois streams-Volume 2, Illinois River Basin, by R.W. Healy, 1979. (AD A082473)

WRI 82-13. Time of concentration and storage coefficient values for Illinois streams, by J.B. Graf, George Garklavs, and K.A. Oberg, 1982. (PB 82-219320) 
WRI 82-16. Hydrologic characteristics of surface-mined land reclaimed by sludge irrigation, Fulton County, Illinois, by G.L. Patterson, R.F. Fuentes, and L.G. Toler, 1982. (PB 83-124982)

WRI 82-22. A technique for estimating time of concentration and storage coefficient values for Illinois streams, by J.B. Graf, George Garklavs, and K.A. Oberg, 1982. (PB 82-218793)

\section{WRIR/ESIC}

The following reports may be ordered, free of charge, while supplies last, from the District Chief, U.S. Geological Survey, 102 E. Main Street, 4th Floor, Urbana, IL 61801 (phone 217-398-5353). The reports are sold by the U.S. Geological Survey, Earth Science Information Center (ESIC), Open-File Report Section, Box 25286, MS 517, Denver Federal Center, Denver, CO 80225-0046 (phone 303-236-7476).

82-4047. Hydrologic effects of storing liquified sewage sludge on strip-mine land, Fulton County, Illinois, by G.L. Patterson. 1982.

82-4073. Runoff, sediment transport, and water quality in a northern Illinois agricultural watershed before urban development, 1979-81, by H.E. Allen, Jr. and J.R. Gray. 1984.

83-4048. Water in sand and gravel deposits in McHenry County, Illinois, by J.R. Nicholas and J.T. Krohelski. 1984.

83-4125. Hydrogeology of a low-level radioactive-waste disposal site near Sheffield, Illinois, by J.B. Foster, J.R. Erickson, and R.W. Healy. 1984.

83-4136. Measurement of bedload discharge in nine Illinois streams with the Helley-Smith sampler, by J.B. Graf. 1983.

83-4265. Runoff and water-quality characteristics of surfacemined lands in Illinois, by T.P. Brabets. 1984.

84-4003. Estimates of long-term suspended-sediment loads in Bay Creek at Nebo, Pike County, Illinois, 1940-80, by T.R. Lazaro, K.K. Fitzgerald, and L.R. Frost, Jr. 1984.

84-4037. Evaluation of a hydrograph-shifting method for estimating suspended-sediment loads in Illinois streams, by L.R. Frost, Jr. and L.J. Mansue. 1984.

84-4123. Cost effectiveness of the U.S. Geological Survey's stream-gaging program in Illinois, by D.M. Mades and K.A. Oberg. 1984.

84-4165. Hydrogeology of the Cambrian-Ordovician aquifer system at a test well in northeastern Illinois, by J.R. Nicholas, M.G. Sherrill, and H.L. Young. 1987.

84-4180. Quality of water in the alluvial aquifer, American Bottoms, East St. Louis, Illinois, by D.C. Voelker. 1984.
84-4183. Hydrogeologic setting east of a low-level radioactivewaste disposal site near Sheffield, Illinois, by J.B. Foster, George Garklavs, and G.W. Mackey. 1984.

84-4205. U.S. Geological Survey research in radioactive waste disposal, fiscal year 1982, by Robert Schneider and N.J. Trask. 1984. (Sheffield, Illinois, by J.B. Foster, R.W. Healy, and J.R. Gray, p. 90-93, and Argonne National Laboratory site, Illinois, by J.R. Nicholas, p. 93-95.)

84-4256. Hydrology of a surface coal mined area in Randolph County, Illinois, by J.V. Borghese and A.R. Klinger. 1984.

84-4311. Low-flow characteristics of streams in the Kishwaukee River Basin, Illinois, by H.E. Allen, Jr. and E.A. Cowan. 1985.

84-4355. A gazetteer of surface-mine lakes, Eastern Interior Coal Province, Illinois, by D.C. Voelker. 1985.

85-4228. Concepts and data-collection techniques used in a study of the unsaturated zone at a low-level radioactive-waste disposal site near Sheffield, Illinois, by R.W. Healy, M.P. deVries, and R.G. Striegl. 1986.

85-4344. Assessment of low-flow water quality in the Du Page River, Illinois, by W.O. Freeman, A.R. Schmidt, and J.K. Stamer. 1986.

86-4008. Estimating generalized skew of the log-Pearson Type III distribution for annual peak floods in Illinois, by K.A. Oberg and D.M. Mades. 1987.

86-4072. Evaluation of the U.S. Geological Survey's gagingstation network in Illinois, by D.M. Mades and K.A. Oberg. 1986.

86-4112. Channel-storage/discharge relations for the Peoria and La Grange Dams on the Illinois River in Illinois, by George Garklavs, A.R. Klinger, and D.M. Mades. 1986.

86-4153. Hydrogeology, ground-water flow, and tritium movement at a low-level radioactive-waste disposal site near Sheffield, Illinois, by George Garklavs and R.W. Healy. 1986.

86-4156. Technique for predicting ground-water discharge to surface coal mines and resulting changes in head, by L.S. Weiss, D.L. Galloway, and A.L. Ishii. 1986.

86-4182. Water use in the United States, 1980, by W.B. Solley, N.L. Barber, and C.F. Merk. 1986.

86-4323. Assessment of low-flow water quality in Richland Creek, Illinois, by W.O. Freeman and A.R. Schmidt. 1986.

87-4009. U.S. Geological Survey research in radioactive waste disposal, fiscal years 1983, 1984, and 1985, by G.A. Dinwiddie and N.J. Trask. 1986. (Sheffield, Illinois, by B.J. Ryan, J.R. Gray, R.G. Striegl, and R.W. Healy, p. 80-84, and Argonne National Laboratory site, Illinois, by J.R. Nicholas and A.M. Shapiro, p. 84-85.) 
87-4024. Assessment of water quality and factors affecting dissolved oxygen in the Sangamon River, Decatur to Riverton, Illinois, summer 1982, by A.R. Schmidt and J.K. Stamer. 1987.

87-4106. Traveltime and dispersion in the Illinois River, Marseilles to Peoria, Illinois, by E.E. Zuehls. 1987.

87-4151. Investigation of techniques to estimate rainfall-loss parameters for Illinois, by L.S. Weiss and A.L. Ishii. 1987.

87-4207. Technique for estimating flood-peak discharges and frequencies on rural streams in Illinois, by G.W. Curtis. 1987.

87-4226. Discharge ratings for control structures at McHenry Dam on the Fox River, Illinois, by G.G. Fisk. 1988.

88-4025. Distribution of gases in the unsaturated zone at a lowlevel radioactive-waste disposal site near Sheffield, Illinois, by R.G. Striegl. 1988.

88-4111. Quality of water from public-supply wells in principal aquifers of Illinois, 1984-87, by D.C. Voelker. 1989.

88-4141. Assessment of processes affecting low-flow water quality of Cedar Creek, west-central Illinois, by A.R. Schmidt, W.O. Freeman, and R.D. McFarlane. 1989.

89-4027. A numerical solution for the diffusion equation in hydrogeologic systems, by A.L. Ishii, R.W. Healy, and R.G. Striegl. 1989.

89-4041. An inventory and evaluation of biological investigations that relate to stream-water quality in the upper Illinois River Basin of Illinois, Indiana, and Wisconsin, by D.W. Steffeck and R.G. Striegl. 1989.

89-4081. Hydrogeology and results of aquifer tests in the vicinity of a hazardous-waste disposal site near Byron, Illinois, by R.T.Kay, D.N. Olson, and B.J. Ryan. 1989.

89-4088. Storm runoff and its effects on the water quality and bottom-material quality of Cedar Creek, westcentral Illinois, 1985-86, by W.O. Freeman, A.R. Schmidt, and R.D. McFarlane. 1989.

89-4106. Techniques for computing discharge at four navigation dams on the Illinois and Des Plaines Rivers in Illinois, by D.M. Mades, L.S. Weiss, and J.R. Gray. 1991.
89-4124. Determination of hydraulic properties in the vicinity of a landfill near Antioch, Illinois, by R.T. Kay and J.D. Earle. 1990.

90-4116. Changes in chloride concentration in water from municipal wells that tap aquifers in rocks of Cambrian and Ordovician age in northeastern Illinois, 1915-84, by G.O. Balding. 1991.

90-4162. U.S. Geological Survey National Computer Technology Meeting: Proceedings, Phoenix, Arizona, November 14-18, 1988, edited by B.H. Balthrop, and J.E. Terry. 1991.

Statistical and graphical methods used to describe ground-water quality in Illinois, by R.H. Coupe and K.L. Warner.

90-4166. Determination of water use in Rockford and Kankakee areas, Illinois, by J.K. LaTour. 1991.

91-4034 U.S. Geological Survey Toxic Substances Hydrology Program: Proceedings of the technical meeting, Monterey, California, March 11-15, 1991, edited by G.E. Mallard and D.E. Aronson. 1991.

Triazine herbicides in selected streams in Illinois during storm events, spring 1990, by R.H. Coupe and G.P. Johnson.

91-4062. Floods of June 13-14, 1981, and December 2-12, 1982, in Illinois, by A.L. Ishii. 1991.

91-4084. U.S. Geological Survey research in radioactive waste disposal: fiscal years 1986-1990, N.J. Trask and P.R. Stevens, comps. 1991. (Sheffield, Ill., by P.C. Mills, p. 40-47.)

92-4095. Overview and bibliography of methods for evaluating the surface-water-infiltration component of the rainfall-runoff process, by R.B. King. 1992.

92-4149. Floods of September 26-October 4, 1986, and August 14-17, 1987, in Illinois, by G.O Balding and A.L. Ishii. 1993.

93-4048. Comparison, analysis, and estimation of discharge data from two acoustic velocity meters on the Chicago Sanitary and Ship Canal at Romeoville, Illinois, by C.S. Melching and K.A. Oberg. 1993.

93-4056. Surface-water and streambed-sediment quality of streams draining surface-mined land reclaimed with sewage sludge, Fulton County, Illinois, 1972-89, by R.M. Coupe and J.A. Macy. 1993.

93-4089. Contribution of return flows to streamflow in selected stream reaches in Illinois, 1988-89, by J.K. LaTour. 1993. 


\section{Open-File Reports (Earth Science Information Center)}

Open-File Reports are informal manuscripts, maps, and other material made available to the public. The following reports may be ordered, free of charge, while supplies last, from the District Chief, U.S. Geological Survey, 102 E. Main Street, 4th Floor, Urbana, IL 61801 (phone 217-398-5353). The reports are sold by the U.S. Geological Survey, Earth Science Information Center, Open-File Reports Section, Box 25286, MS 517, Denver Federal Center, Denver, CO 80225 (phone 303-236-7476).

77-867. Sediment transport to the Fox Chain of Lakes, Illinois, by T.P. Brabets. 1977.

79-210. Water-table contour map of land reclamation site, Fulton County, Illinois, by R.F. Fuentes and G.L. Patterson. 1979.

79-1545. Preliminary report on the hydrogeology of a low-level radioactive-waste disposal site near Sheffield, Illinois, by J.B. Foster and J.R. Erickson. 1980.

80-775. Low-level radioactive-waste burial at the Palos Forest Preserve, Illinois, Part 1. Preliminary finitedifference models of steady state ground-water flow, by J.C. Olimpio. 1980.

81-1009. Stage-discharge relations at dams on the Illinois and Des Plaines Rivers in Illinois, by D.M. Mades. 1981.

82-692. Data for wells at the low-level radioactive-waste burial site in the Palos Forest Preserve, Illinois, by J.C. Olimpio. 1982.

82-693. Work Plan for the Sangamon River Basin, Illinois, by J.K. Stamer and D.M. Mades. 1983.

82-1001. Proceedings-Illinois Water-Data-Users Meeting, Peoria, Illinois, February 23-24, 1982, by L.G. Toler. 1982.

83-926. Geologic and hydrologic data collected during 19761984 at the Sheffield low-level radioactive-waste disposal site and adjacent areas, Sheffield, Illinois, by J.B. Foster, George Garklavs, and G.W. Mackey. 1984.

84-584. Illinois ground-water observation network - A preliminary planning document, by L.R. Frost, Jr., Michael O'Hearn, J.P. Gibb, and M.G. Sherrill. 1984.

84-603. Effects of urban runoff on Lake Ellyn at Glen Ellyn, Illinois, by R.G. Striegl. 1985.
84-856. Measurement of ground-water velocity using rhodamine WT dye near Sheffield, Illinois, by George Garklavs and L.G. Toler. 1985.

85-629. Sources of climatologic, hydrologic, and hydraulic information in the Illinois River Basin, Illinois, Indiana, and Wisconsin, by G.W. Curtis. 1986.

86-130. Water-resources activities in Illinois, 1985, by M.L. Garrelts. 1986.

86-416(W). Observation-well network in Illinois, 1984, by D.C. Voelker. 1986.

87-039. Water-resources activities in Illinois, 1986, by M.L. Garrelts. 1987.

87-473. Surface-water-quality assessment of the upper Illinois River Basin in Illinois, Indiana, and Wisconsin: Project description, by D.M. Mades. 1987.

87-538. Water-quality data from the observation-well network in Illinois, 1985-87, by D.C. Voelker, D.J. Oberg, and M.J. Grober. 1988.

87-543. Data-collection methods and data summary for the assessment of water quality in Cedar Creek, westcentral Illinois, by R.D. McFarlane, W.O. Freeman, and A.R. Schmidt. 1987.

87-698. Water-resources activities in Illinois, 1987, by M.L. Garrelts. 1988.

88-143. U.S. Geological Survey ground-water studies in Illinois, by D.C. Voelker, J.R. Nicholas, and K.L. Norton. 1988. (Water Fact Sheet)

89-031. Water-resources activities of the U.S. Geological Survey in Illinois, 1988, by M.L. Garrelts. 1989.

89-409. U.S. Geological Survey Second National Symposium on Water Quality: Abstracts of the technical sessions, Orlando, Florida, November 12-17, 1989, compiled by G.L. Pederson and M.M.Smith. 1989.

Surface-water quality of the upper Illinois River Basin in Illinois, Indiana, and Wisconsin: Analysis of existing information, by S.F. Blanchard.

Relations between fish populations and water quality in the upper Illinois River Basin in Illinois, Indiana, and Wisconsin: Analysis of existing information, by P.M. Ruhl and R.G. Striegl.

Using a geographic information system to relate human and natural factors to stream water quality in the upper Illinois River Basin in Illinois, Indiana, and Wisconsin, by F.A. Stanke. 
Occurrence and distribution of nutrients and dissolved oxygen in the upper Illinois River Basin in Illinois, Indiana, and Wisconsin: Results of a 1988 low-flow synoptic survey, by P.J. Terrio.

89-625. Water-resources activities of the U.S. Geological Survey in Illinois, 1989, by M.L. Garrelts. 1990.

90-375. Availability and suitability of municipal wastewater information for use in a National water-quality assessment: A case study of the upper Illinois River Basin in Illinois, Indiana, and Wisconsin, by J.S. Zogorski, S.F. Blanchard, R.D. Romack, and F.A. Fitzpatrick. 1990.

90-382. Well-construction and hydrogeologic data for observation wells in the vicinity of a low-level radioactive-waste disposal site near Sheffield, Illinois, by L.J. Mansue and P.C. Mills. 1991.

90-571. Surface-water-quality assessment of the upper Illinois River Basin in Illinois, Indiana, and Wisconsin: Geochemical data for fine-fraction streambed sediment from high- and low-order streams, 1987, by J.A. Colman and R.F. Sanzolone. 1991.

91-088. Triazine herbicides in selected streams in Illinois during storm events, spring 1990, by R.H. Coupe and G.P. Johnson (p. 65), in U.S. Geological Survey Toxic Substances Hydrology Program; abstracts of the technical meeting, Monterey, California, March 11-15, 1991, compiled by G.E. Mallard and D.A. Aronson. 1991 .

91-209. Development and organization of a geographic information system data base and its application to investigation of rainfall/runoff-model parameters in Illinois, by A.R. Schmidt and R.D. Romack. 1991.

91-220. Hydrogeologic information in the Great Lakes Basin, United States, and application of a geographic information system to public-supply wells and hazardous-waste sites, by K.L. Warner, J.D. Earle, and M.G. Sherrill. 1991.

92-149. Floating sample-collection platform with stageactivated automatic water sampler for streams with large variation in stage, by S.R. Tarte, A.R. Schmidt, and D.J. Sullivan. 1992.

92-451. Water-resources activities of the U.S. Geological Survey in Illinois, 1990, by G.O. Balding. 1992.

92-452. Water resources activities of the U.S. Geological Survey in Illinois, 1991, by G.O. Balding. 1992.

92-467. Surface-water-quality assessment of the upper Illinois River Basin in Illinois, Indiana, and Wisconsin: Data on manmade nonagricultural volatile and semivolatile organic chemicals in water, May 1988 through March 1990, by F.A. Fitzpatrick and J.A. Colman. 1993.
92-485. Rainfall in and near Du Page County, Illinois, February 1986-September 1991, by J.J. Duncker, T.J. Vail, and J.D. Earle. 1993.

93-402. Vertical distribution of hydraulic characteristics and water quality in the three boreholes in the GalenaPlatteville Aquifer at the Parson's Casket Hardware superfund site, Belvidere, Illinois, 1991, by P.C. Mills. 1993.

93-403. Hydrogeology and water quality of the GalenaPlatteville Aquifer at the Parson's Casket Hardware superfund site, Belvidere, Illinois, 1991, by P.C. Mills. 1993.

93-404. Hydrogeology and water quality of the GalenaPlatteville Aquifer at the Parson's Casket Hardware superfund site, Belvidere, Illinois, 1991-1992, by P.C. Mills. 1993.

93-454. U.S. Geological Survey Toxic Substances Hydrology Program-abstracts of the technical meeting, Colorado Springs, Colorado, September 20-24, 1993: compiled by D.W. Morganwalp and D.A. Aronson. 1993.

Annual use and transport of agricultural chemicals in the Mississippi River, 1991-92, by W.A. Battaglin, D.A. Goolsby, and R.H. Coupe.

Transport and concentrations of selected herbicides and nitrate in the Sangamon River, Illinois, April 1991 - March 1992, by G.P. Johnson and R.H. Coupe.

93-649. Water-resources activities of the U.S. Geological Survey in Illinois, 1992, by G.O. Balding. 1994.

\section{Water-Resources Investigations Open-File Reports}

The following reports are available free of charge, while supplies last, from the District Chief, U.S. Geological Survey, 102 East Main Street, 4th Floor, Urbana, IL 61801 (phone 217-398-5353).

76-87. Index to water-resources data for Illinois, by D.E. Winget. 1976.

81-403. Hydrology of Area 35, Eastern Region, Interior Coal Province, Illinois and Kentucky, by E.E. Zuehls, G.L. Ryan, D.B. Peart, and K.K. Fitzgerald. 1981.

81-636. Hydrology of Area 25, Eastern Region, Interior Coal Province, Illinois, by E.E. Zuehls, G.L. Ryan, D.B. Peart, and K.K. Fitzgerald. 1981. 
82-858. Hydrology of Area 29, Eastern Region, Interior Coal Province, Illinois, by K.K. Fitzgerald, C.A. Peters, and E.E. Zuehls. 1983.

82-1005. Hydrology of Area 30, Eastern Region, Interior Coal Province, Illinois and Indiana, by D.J. Wangsness and others. 1983.

83-544. Hydrology of Area 28, Eastern Region, Interior Coal Province, Illinois, by E.E. Zuehls, K.K. Fitzgerald, and C.A. Peters. 1984.

84-707. Hydrology of Area 27, Eastern Region, Interior Coal Province, Illinois, by E.E. Zuehls. 1987.

85-342. Hydrology of Area 31, Eastern Region, Interior Coal Province, Illinois and Indiana, by E.E. Zuehls. 1987.

\section{Miscellaneous Reports}

The following miscellaneous reports were developed in cooperation with other State of Illinois agencies and published by those agencies. The reports are available, for inspection only, at the Illinois District Office of the U.S. Geological Survey. Information about these reports may be obtained from the District Chief, U.S. Geological Survey, 102 East Main Street, 4th Floor, Urbana, IL 61801 (phone 217-398-5353).

Carns, J.M., 1973, Magnitude and frequency of floods in Illinois.

Curtis, G.W., 1969, Statistical summaries of Illinois streamflow data.

Kirk, J.R., 1987, Water withdrawals in Illinois, 1986.

Kirk, J.R., Jarboe, Jacquelyn, Sanderson, E.W., and others, 1979, Water withdrawals in Illinois, 1978.

Kirk, J.R., Jarboe, Jacquelyn, Sanderson, E.W., and others, 1982, Water withdrawals in Illinois, 1980.

Kirk, J.R., Sanderson, E.W., and Sasman, R.T., 1984, Water withdrawals in Illinois, 1982.

Kirk, J.R., Hlinka, K.J., Sasman, R.T., and Sanderson, E.W., 1985, Water withdrawals in Illinois, 1984.

Kirk, J.R., and Sanderson, E.W., 1982, Illinois water inventory program.

Lara, O.G., 1970, Low-flow frequencies of Illinois streams.

Mitchell, W.D., 1948, Unit hydrographs in Illinois. -1950 , Water-supply characteristics of Illinois streams. 1954, Floods in Illinois-Magnitude and frequency.
1957, Flow duration of Illinois streams.

Prugh, B.J., Jr., 1976, Depth and frequency of floods in Illinois.

Sieber, C.R., 1970, A proposed streamflow-data program for Illinois.

Visocky, A.P., Sherrill, M.G., and Cartwright, Keros, 1985, Geology, hydrology, and water quality of the Cambrian and Ordovician Systems in northern Illinois.

\section{Water-Data Reports}

The annual State Water-Data Report contains surface- and ground-water data for Illinois that has been collected by the USGS in cooperation with other Federal, State, and local agencies. These official USGS reports have an identification number consisting of the twoletter State abbreviation, the last two digits of the water year, and the volume number. The Illinois water-data reports are available free of charge, while supplies last, for every year beginning in 1971, from the District Chief, U.S. Geological Survey, 102 East Main Street, 4th Floor, Urbana, IL 61801 (phone 217-398-5353).

The reports may also be purchased as hard copy or microfiche from the National Technical Information Service (NTIS), U.S. Department of Commerce, 5285 Port Royal Road, Springfield, VA 22161 (phone 703487-4650).

The following are the most recently published water-data reports for Illinois. The NTIS ordering number is given in parentheses at the end of the citation:

LaTour, J.K., Richards, T.E., and Coupe, R.H., 1993, Water resources data - Illinois, water year 1992, volume 2, Illinois River Basin: U.S. Geological Survey Water-Data Report IL-92-2, 315 p. (PB93-232718).

Maurer, J.C., Richards, T.E., LaTour, J.K., and Coupe, R.H., 1993, Water resources data - Illinois, water year 1992, volume 1, Illinois except Illinois River Basin: U.S. Geological Survey Water-Data Report IL-92-1, 261 p. (PB93-232700).

\section{Conference Papers and Abstracts and Journal Articles}

Conference papers and abstracts and journal articles by USGS personnel, in the Illinois District, are printed in non-USGS publications and are not available from the USGS. The abstracts listed are those that were published in 1993 or are those that have not been listed 
in a previous activities report. Typically, the abstracts summarize the principal conclusions of an author's current work but contain little supporting data.

Lessons learned in a hydrogeological case at Sheffield, Illinois, by J.B. Foster, in Proceedings of the Symposium on Low-Level Waste Disposal, Site Characterization and Monitoring, June 16-17, 1982, Arlington, Virginia, NUREG/CP-0028, CONF-820674, Vol. 2, p. 237-244.

Preliminary results of a study of the unsaturated zone at the low-level radioactive-waste disposal site near Sheffield, Illinois, by R.W. Healy, in Proceedings of the Fifth Annual Participants' Information Meeting, DOE Low-Level Waste Management Program, August 30-September 1, 1983, Denver, Colorado, CONF-8308106, p. 669-673.

Accumulation of sediment and heavy metals in Lake Ellyn, an urban lake at Glen Ellyn, Illinois, by E.A. Cowan, in Proceedings of Urban Effects on Water Quality and Quantity, October 20-21, 1983, Urbana, Illinois, Illinois Department of Energy and Natural Resources Document No. 84/06, p. 280-292.

Effects of an urban lake on stormwater runoff and quality, by R.G. Striegl, in Proceedings of Urban Effects on Water Quality and Quantity, October 20-21, 1983, Urbana, Illinois, Illinois Department of Energy and Natural Resources Document No. $84 / 06$, p. $74-83$.

Study of the unsaturated zone at a low-level radioactive-waste disposal site, by R.W. Healy, C.A. Peters, M.P. deVries, P.C. Mills, and D.L. Moffett, in Proceedings of the Characterization and Monitoring of the Vadose (Unsaturated) Zone, National Water Well Association, December 8-10, 1983, Las Vegas, Nevada, p. 820-830.

Infiltration through trench caps at a low-level radioactive-waste disposal site, by R.W. Healy, in Proceedings of the National Conference on Advancees in Infiltration, December 12-13, 1983, Chicago, Illinois, American Society of Agricultural Engineers Publication 11-83, p. 376.

Predicting ground-water drainage to surface mines, by L.S. Weiss and D.L. Galloway, in Proceedings of Water for Resource Development, ASCE Hydraulics Division Specialty Conference, August 14-17, 1984, Coeur d' Alene, Idaho, p. 184-188.

Runoff, sediment transport, and landform modifications near Sheffield, Illinois, by J.R. Gray, in Proceedings of the Sixth Annual Participants' Information Meeting, DOE Low-Level Waste Management Program, September 11-13, 1984, Denver, Colorado, CONF-8409115, p. 534-544.

Methods for determining the transport of radioactive gases in the unsaturated zone, by R.G. Striegl, in Proceedings of the Sixth Annual Participants' Information Meeting, DOE Low-Level Waste Management Program, September 11-13, 1984, Denver, Colorado, CONF-8409115, p. 579-587.
Ground-water drainage to surface mines refined, by L.S. Weiss, in Hydraulics and Hydrology in the Small Computer Age, Volume 1, Proceedings of the Specialty Conference sponsored by the Hydraulics Division of the American Society of Civil Engineers, Aug. 12-17, 1985, Lake Buena Vista, Florida, p. 621-626.

Collapse and erosion at the low-level radioactive-waste burial site near Sheffield, Illinois, by J.R. Gray and L.L. McGovern, in Proceedings of the Seventh Annual Participants' Information Meeting, DOE Low-Level Waste Management Program, September 11-13, 1985, Las Vegas, Nevada, CONF-8509121, p. 737-753.

Variability in the partial pressures of gases in the unsaturated zone adjacent to a low-level radioactive-waste disposal site near Sheffield, Illinois, by R.G. Striegl and P.M. Ruhl, in Proceedings of the Seventh Annual Participants' Information Meeting, DOE Low-Level Waste Management Program, September 11-13, 1985, Las Vegas, Nevada, CONF-8509121, p. $725-736$.

Chemistry of pore water in the unsaturated zone at a low-level radioactive-waste disposal site near Sheffield, Illinois, by C.A. Peters, in Proceedings of the NWWA Conference on Characterization and Monitoring of the Vadose (Unsaturated) Zone, November 19-21, 1985, Denver, Colorado, p. 272-282.

Runoff, sediment transport, and surface collapse at a low-level radioactive-waste burial site near Sheffield, Illinois, by J.R. Gray and C.A. Peters, in Proceedings of the 1985 Symposium on Surface Mining, Hydrology, Sedimentology, and Reclamation, December 9-13, 1985, Lexington, Kentucky, p. 389.

Landform modifications at a nuclear-waste burial site, by J.R. Gray, in Proceedings of the Fourth Federal Interagency Sedimentation Conference, Volume 1, March 1986, Las Vegas, Nevada, p. 3-93 to 3-102.

Effect of rainfall excess calculations on modeled hydrograph accuracy and unit-hydrograph parameters, by George Garklavs and K.A. Oberg, in Water Resources Bulletin, v. 22, no. 4, August 1986, p. 565-572.

Rainfall-loss parameter estimation for Illinois, by L.S. Weiss and A.L. Ishii, in Proceedings of Water Forum '86: World Water Issues in Evolution, August 4-6, 1986, Long Beach, California, p. 682-689.

Water and tritium movement in variably saturated glacial deposits near Sheffield, Illinois, by P.C. Mills and R.W. Healy, in Proceedings of the FOCUS Conference on Midwestern Ground Water Issues, April 21-23, 1987, Indianapolis, Indiana, p. 169-186.

Estimating fracture connectivity using measurements of borehole temperatures during pumping, by S.E. Silliman, J.R. Nicholas, and A.M. Shapiro, in Proceedings of the FOCUS Conference on Midwestern Ground Water Issues, April 21-23, 1987, Indianapolis, Indiana, p. 231-248. 
Estimation of navigation-dam discharge in Illinois, by L.S. Weiss, in Proceedings of the 1987 ASCE Conference on Hydraulic Engineering, August 3-7, 1987, Williamsburg, Virginia, p. 641-647.

Geographic estimation of runoff-model parameters by A.R. Schmidt, L.S. Weiss, and K.A. Oberg, in Proceedings of the ASCE Engineering Hydrology Symposium, August 3-7, 1987, Williamsburg, Virginia, p. 551-554.

Transport of methane in the unsaturated zone by R.G. Striegl and A.L. Ishii, in Ground Water, v. 25, no. 5, September-October 1987, p. 611.

Diffusion of radioactive carbon dioxide in the unsaturated zone near buried low-level radioactive waste, by R.G. Striegl, in Ground Water, v. 25, no. 5, September-October 1987, p. 613.

Hydrogeology of the Byron/Johnson Salvage Yard Superfund site near Byron, Illinois, by R.T. Kay, B.J. Ryan, E.J. Mears, and D.J. Yeskis in Proceedings of the ASCE Water Resources Symposium, October 21-22, 1987, Rosemont, Illinois, p. 1-11.

Suspended sediment and metals removal from urban runoff by a small lake, by R.G. Striegl, in Water Resources Bulletin, v. 23, no. 6, December 1987, p. 985-996.

Leachate movement through unsaturated sand at a low-level radioactive-waste disposal site in northwestern Illinois, by P.C. Mills and M.P. deVries, in Proceedings, Session III: Disposal technology and facility development, Tenth Annual DOE Low-Level Waste Management Conference, August 30 to September 1, 1988, Denver, Colorado, p. 54-68.

Water balance at a low-level radioactive-waste disposal site, by R.W. Healy, J.R. Gray, M.P. deVries, and P.C. Mills, in Water Resources Bulletin, v. 25, no. 2, April 1989, p. 381-390.

Assessing the validity of the channel model of fracture aperture under field conditions, by A.M. Shapiro and J.R. Nicholas, in Water Resources Research, v. 25, no. 5, May 1989, p. 817-828.

Seepage through a hazardous-waste trench cover, by R.W. Healy, in Journal of Hydrology, v. 108, no. 1-4, June 1989, p. 213-234.

Diffusion and consumption of methane in an unsaturated zone in north-central Illinois, by R.G. Striegl and A.L. Ishii, in Journal of Hydrology, v. 111, no. 1-4, November 1989, p. 133-143.

Use of a geographic information system in the upper Illinois River Basin pilot project of the National Water-Quality Assessment Program, by F.A. Fitzpatrick, in Workshop proceedings; Remote sensing and GIS applications to nonpoint source planning, U.S. Environmental Protection Agency, April 1991, p. $55-66$.

Variability of an unsaturated sand unit underlying a radioactivewaste trench, by R.W. Healy and P.C. Mills, in Soil Science Society of America Journal, v. 55, no. 4, July-August 1991, p. 899-907.

Sediment and water quality in the upper Illinois River Basin, by A.R. Schmidt in Proceedings, 1991 Governor's Conference on the Management of the Illinois River System, October 22-23, 1991, Peoria, Illinois, p. 78-87.
Geochemical characterization of streambed sediment in the upper Illinois River Basin, by J.A. Colman and R.F. Sanzolone, in Water Resources Bulletin, v. 28, no. 5, October 1992, p. 933-950.

Herbicides in the Mississippi River and its major tributaries, April through June 1991 [abs.], by R.H. Coupe and D.A. Goolsby, in Proceedings of the Mississippi River Research Consortium, Inc., v. 24, 1992, and in Abstracts-Agricultural Chemicals Short Course, November 23-24, 1992, Jefferson City, Missouri.

The role of the U.S. Geological Survey in the Great Lakes Basin, by K.L. Warner, in U.S. Water News, December 1992, v. 9, no. 6 , p. 21.

Application of a transport model to verify a one-dimensional, unsteady-flow model [abs.], by M.J. Turner and A.R. Schmidt, in transactions, American Geophysical Union, 1993 Fall meeting, December 6-10, 1992, San Francisco, Calif., p. 268.

Assessing the effect of pesticides in agricultural runoff on aquatic life in the Sangamon River near Monticello, Illinois, by R.H. Coupe, M.S. Henebry, and M.R. Branham, in Water Science and Technology, v. 28, no. 3-5, 1993, printed in Great Britain, p. 569-572.

Integrating well logs into a multiple-scale investigation of a fractured sedimentary aquifer, by F.L. Paillet, R.T. Kay, Douglas Yeskis, and W.H. Pedler, in The Log Analyst, v. 34, no. 1, JanuaryFebruary 1993, p. 24-40.

Water-level, velocity, and dye measurements in the Chicago tunnels, by K.A. Oberg and A.R. Schmidt, in Hydraulic Engineering '93, v. 2, Proceedings of the 1993 Conference, American Society of Civil Engineers, Hydraulics Division, July 25-30, 1993, San Francisco, Calif., p. 1476-1481.

Importance of hydraulic-model uncertainty in flood-stage estimation, by Satvinder Singh and C.S. Melching, in Hydraulic Engineering '93, v. 2, Proceedings of the 1993 Conference, American Society of Civil Engineers, Hydraulics Division, July 25-30, 1993, San Francisco, Calif., p. 1939-1944.

Effect of boundary condition data selection on unsteady-flow model calibration, by A.L. Ishii and J.E. Wilder, in Proceedings of XXV Congress of International Association for Hydraulic Research, special lectures, technical session A, flood and drought, v. 1, August 30-September 3, 1993, Tokyo, Japan, p. 193-200.

Inorganic constituents in ground water from public-supply wells in Illinois [abs.], by K.L. Warner, in 38th Annual Midwest Ground Water Conference Program and Abstracts, October 6-8, 1993, Champaign, Illinois.

An alternative field methodology for investigating a fractured bedrock, Superfund site [abs.], by Bill Bolen, Doug Yeskis, Craig Thomas, and Bob Kay, in 38th Annual Midwest Ground Water Conference Program and Abstracts, October 6-8, 1993, Champaign, Illinois. 
A preliminary conceptual hydrogeologic model of the GalenaPlatteville Aquifer in northern Illinois [abs.], by P.C. Mills, J.M. Howard, D.J. Yeskis, and R.T. Kay, in 38th Annual Midwest Ground Water Conference Program and Abstracts, October 6-8, 1993, Champaign, Illinois.

An evaluation of single-hole aquifer tests on a fractured bedrock Superfund site [abs.], by Doug Yeskis, Luanne Vanderpool, Bob Kay, and Colin Booth, in 38th Annual Midwest Ground Water Conference Program and Abstracts, October 6-8, 1993, Champaign, Illinois.

Data collection for water-hammer analysis of the deep tunnel, Chicago, Illinois [abs.], by J.J. Duncker and K.A. Oberg, in Program and Abstracts, Illinois Section of the American Water Resources Association, 1993 Biennial Conference, October 26, 1993, Northern Illinois University, De Kalb, Illinois.

Evaluation of four methods for computing continuous discharge record for the Illinois River at Valley City [abs.], by L.C. Schideman and K.A. Oberg, in Program and Abstracts, Illinois Section of the American Water Resources Association, 1993 Biennial Conference, October 26, 1993, Northern Illinois University, De Kalb, Illinois.
Acoustic doppler current profiler streamflow measurements in Illinois [abs.], by K.A. Oberg, in Program and Abstracts, Illinois Section of the American Water Resources Association, 1993 Biennial Conference, October 26, 1993, Northern Illinois University, De Kalb, Illinois.

Regional rainfall-runoff relations for small watersheds in Lake County, Illinois [abs.], by J.J. Duncker, T.J. Vail, and C.S. Melching, in Program and Abstracts, Illinois Section of the American Water Resources Association, 1993 Biennial Conference, October 26, 1993, Northern Illinois University, De Kalb, Illinois. 


\section{WHERE TO OBTAIN ADDITIONAL INFORMATION ON U.S. GEOLOGICAL SURVEY PROGRAMS IN ILLINOIS}

In addition to the reports and abstracts listed above, further information may be obtained regarding water, maps, and geology by contacting the following offices of the U.S. Geological Survey:

WATER

\author{
District Chief \\ U.S. Geological Survey \\ 102 East Main Street, 4th floor \\ Urbana, Illinois 61801 \\ Phone: (217) 398-5353
}

MAPS

\author{
Chief, Mid-Continent Mapping Center \\ Earth Science Information Center \\ U.S. Geological Survey \\ 1400 Independence Road \\ Rolla, Missouri 65401
}

Phone: (314) 341-0851

\section{GEOLOGY}

\author{
Assistant Chief Geologist, Eastern Region \\ U.S. Geological Survey \\ 953 National Center \\ Reston, Virginia 22092 \\ Phone: (703) 648-6660
}

\section{GENERAL INFORMATION}

\author{
U.S. Geological Survey \\ Earth Science Information Center \\ 507 National Center \\ Reston, Virginia 22092 \\ Phone: (800) USA-MAPS
}

\section{REFERENCES}

Balding, G.O., 1994, Water-resources activities of the U.S. Geological Survey in Illinois, 1992: U.S. Geological Survey Open-File Report 93-649, 83 p.

Bhowmik, N.G., and Bogner, W.C., 1981, Sediment transport and hydraulics of flow in the Kankakee River, IllinoisPhase II: Illinois State Water Survey Contract Report 282, 67 p.

Blackwell, C.D., 1993, Directory of assistance centers of the National Water-Data Exchange (NAWDEX): U.S. Geological Survey Open-File Report 93-76, 40 p.

Gilbert, B.K., and Mann, W.B., 1993, The U.S. Geological Survey Federal-State cooperative water-resources program-fiscal year 1992: U.S. Geological Survey Open-File Report 93-120, 33 p.

Gross, D.L., and Berg, R.C., 1981, Geology of the Kankakee River System in Kankakee County, Illinois: Illinois State Geological Survey Environmental Geology Note 92, 80 p.

Ryan, G.H., ed, 1993, Illinois blue book, 1993-1994: State of Illinois, 591 p.

U.S. Geological Survey, 1992, Water Resources Division information guide: Reston, Va., 21 p.

Wendland, W.M.; Kunkel, K.E.; Conner, Glen; and others, 1992, Mean 1961-1990 temperatures and precipitation over the upper Midwest: Illinois State Water Survey Miscellaneous Publication 136, 27 p. 
TABLES 2-5

65 
Table 2. Surface-water stations operated by the Illinois District for which data are published

[C, Crest stage - peak-stage and peak-discharge record only; CQ, Chemical quality; D, Discharge - continuous record of stage and discharge; DS, Discharge with auxiliary slope gage - continuous record of stage and discharge; R, Lake contents - furnished by U.S. Army Corps of Engineers, St. Louis District; S, Stage - continuous record of stage; S/8-Stage at 0800 hours; SD, Suspended sediment]

\begin{tabular}{|c|c|c|}
\hline $\begin{array}{l}\text { Station } \\
\text { Number }\end{array}$ & Station name & $\begin{array}{c}\text { Type of } \\
\text { data }\end{array}$ \\
\hline 03336645 & Middle Fork Vermilion River above Oakwood, Ill. & D \\
\hline 03337000 & Boneyard Creek at Urbana, Ill. & D \\
\hline 03338780 & North Fork Vermilion River near Bismarck, Ill. & $\mathrm{D}$ \\
\hline 03339000 & Vermilion River near Danville, Ill. & $\mathrm{D}$ \\
\hline 03343400 & Embarras River near Camargo, Ill. & $\mathrm{D}$ \\
\hline 03345500 & Embarras River at Ste. Marie, Ill. & $\mathrm{D}, \mathrm{CQ}$ \\
\hline 03346000 & North Fork Embarras River near Oblong, Ill. & D \\
\hline 03378000 & Bonpas Creek at Browns, Ill. & $\mathrm{D}$ \\
\hline 03378635 & Little Wabash River near Effingham, Ill. & $\mathrm{D}$ \\
\hline 03379500 & Little Wabash River below Clay City, III. & $\mathrm{D}$ \\
\hline 03380500 & Skillet Fork at Wayne City, Ill. & D \\
\hline 03381495 & Little Wabash River at Main Street at Carmi, Ill. & $\mathrm{CQ}$ \\
\hline 03381500 & Little Wabash River at Carmi, Ill. & DS \\
\hline 03382100 & South Fork Saline River near Carrier Mills, Ill. & $\mathrm{D}$ \\
\hline 03384450 & Lusk Creek near Eddyville, IIl. & $\mathrm{D}$ \\
\hline 03385000 & Hayes Creek at Glendale, Ill. & $\mathrm{C}$ \\
\hline 03612000 & Cache River at Forman, Ill. & $\mathrm{D}$ \\
\hline 05414820 & Sinsinawa River near Menominee, Ill. & $\mathrm{D}$ \\
\hline 05419000 & Apple River near Hanover, Ill. & D \\
\hline 05435500 & Pecatonica River at Freeport, III. & $\mathrm{D}$ \\
\hline 05437500 & Rock River at Rockton, Ill. & $\mathrm{D}$ \\
\hline 05438500 & Kishwaukee River at Belvidere, Ill. & $\mathrm{D}$ \\
\hline 05439000 & South Branch Kishwaukee River at De Kalb, Ill. & $\mathrm{D}$ \\
\hline 05439500 & South Branch Kishwaukee River near Fairdale, Ill. & $\mathrm{D}$ \\
\hline 05440000 & Kishwaukee River near Perryville, IIl. & $\mathrm{D}$ \\
\hline 05443500 & Rock River at Como, Ill. & $\mathrm{D}$ \\
\hline 05444000 & Elkhorn Creek near Penrose, Ill. & $\mathrm{D}$ \\
\hline 05446000 & Rock Creek at Morrison, Ill. & $\mathrm{C}$ \\
\hline 05446500 & Rock River near Joslin, Ill. & $\mathrm{D}, \mathrm{CQ}$ \\
\hline 05447500 & Green River near Geneseo, Ill. & D \\
\hline 05448000 & Mill Creek at Milan, Ill. & $\mathrm{D}$ \\
\hline 05466000 & Edwards River near Orion, Ill. & $\mathrm{D}$ \\
\hline 05466500 & Edwards River near New Boston, Ill. & $\mathrm{D}$ \\
\hline 05467000 & Pope Creek near Keithsburg, Ill. & $\mathrm{D}$ \\
\hline 05468500 & Cedar Creek at Little York, Ill. & $\mathrm{C}$ \\
\hline 05469000 & Henderson Creek near Oquawka, Ill. & D \\
\hline 05495500 & Bear Creek near Marcelline, Ill. & $\mathrm{D}$ \\
\hline 05502020 & Hadley Creek near Barry, Ill. & $\mathrm{C}$ \\
\hline 05512500 & Bay Creek at Pittsfield, Ill. & $\mathrm{D}$ \\
\hline 05518000 & Kankakee River at Shelby, Ind. & SD \\
\hline
\end{tabular}


Table 2. Surface-water stations operated by the Illinois District for which data are published —Continued

\begin{tabular}{|c|c|c|}
\hline $\begin{array}{c}\text { Station } \\
\text { Number }\end{array}$ & Station name & $\begin{array}{c}\text { Type of } \\
\text { data }\end{array}$ \\
\hline 05519000 & Singleton Ditch at Schneider, Ind. & SD \\
\hline 05520500 & Kankakee River at Momence, Ill. & $\mathrm{D}, \mathrm{SD}$ \\
\hline 05525000 & Iroquois River at Iroquois, Ill. & $\mathrm{D}, \mathrm{SD}$ \\
\hline 05525500 & Sugar Creek at Milford, Ill. & $\mathrm{D}$ \\
\hline 05526000 & Iroquois River near Chebanse, Ill. & $\mathrm{D}, \mathrm{SD}$ \\
\hline 05527500 & Kankakee River near Wilmington, Ill. & $\mathrm{D}, \mathrm{SD}$ \\
\hline 05527800 & Des Plaines River at Russell, Ill. & $\mathrm{D}$ \\
\hline 05527950 & Mill Creek at Old Mill Creek, Ill. & $\mathrm{D}$ \\
\hline 05528000 & Des Plaines River near Gurnee, Ill. & $\mathrm{D}$ \\
\hline 05528030 & Bull Creek near Libertyville, Ill. & $\mathrm{D}$ \\
\hline 05528230 & Indian Creek at Prairie View, Ill. & $\mathrm{D}$ \\
\hline 05528500 & Buffalo Creek near Wheeling, IIl. & $\mathrm{D}$ \\
\hline 05529000 & Des Plaines River near Des Plaines, Ill. & D \\
\hline 05529500 & McDonald Creek near Mount Prospect, Ill. & $\mathrm{D}$ \\
\hline 05530000 & Weller Creek at Des Plaines, Ill. & $\mathrm{D}$ \\
\hline 05530990 & Salt Creek at Rolling Meadows, Ill. & $\mathrm{D}$ \\
\hline 05531300 & Salt Creek at Elmhurst, Ill. & $\mathrm{D}$ \\
\hline 05531500 & Salt Creek at Western Springs, Ill. & $\mathrm{D}$ \\
\hline 05532000 & Addison Creek at Bellwood, Ill. & D \\
\hline 05532300 & Salt Creek at Brookfield, Ill. & $\mathrm{S}$ \\
\hline 05532500 & Des Plaines River at Riverside, Ill. & $\mathrm{D}$ \\
\hline 05533000 & Flag Creek near Willow Springs, Ill. & $\mathrm{D}$ \\
\hline 05533400 & Sawmill Creek near Lemont, Ill. & $\mathrm{D}$ \\
\hline 05534500 & North Branch Chicago River at Deerfield, Ill. & $\mathrm{D}$ \\
\hline 05535000 & Skokie River at Lake Forest, Ill. & $\mathrm{D}$ \\
\hline 05535070 & Skokie River near Highland Park, Ill. & $\mathrm{D}$ \\
\hline 05535500 & West Fork of North Branch Chicago River at Northbrook, Ill. & D \\
\hline 05536000 & North Branch Chicago River at Niles, Ill. & D \\
\hline 05536105 & North Branch Chicago River at Albany Avenue at Chicago, Ill. & $\mathrm{D}$ \\
\hline 05536215 & Thorn Creek at Glenwood, Ill. & $\mathrm{D}$ \\
\hline 05536235 & Deer Creek near Chicago Heights, Ill. & $\mathrm{D}$ \\
\hline 05536255 & Butterfield Creek at Flossmoor, Ill. & $\mathrm{D}$ \\
\hline 05536265 & Lansing ditch near Lansing, Ill. & D \\
\hline 05536275 & Thorn Creek at Thornton, Ill. & $\mathrm{D}$ \\
\hline 05536290 & Little Calumet River at South Holland, Ill. & $\mathrm{D}$ \\
\hline 05536340 & Midlothian Creek at Oak Forest, Ill. & $\mathrm{D}$ \\
\hline 05536500 & Tinley Creek near Palos Park, Ill. & $\mathrm{D}$ \\
\hline 05536995 & Chicago Sanitary and Ship Canal at Romeoville, Ill. & D \\
\hline 05537500 & Long Run near Lemont, Ill. & $\mathrm{D}$ \\
\hline 05539000 & Hickory Creek at Joliet, Ill. & $\mathrm{D}$ \\
\hline 05539900 & West Branch Du Page River near West Chicago, Ill. & D \\
\hline 05540060 & Kress Creek at West Chicago, Ill. & $\mathrm{D}$ \\
\hline 05540091 & Spring Brook at Forest Preserve near Warrenville, Ill. & $\mathrm{D}$ \\
\hline 05540095 & West Branch Du Page River near Warrenville, Ill. & $\mathrm{D}$ \\
\hline 05540130 & West Branch Du Page River near Naperville, Ill. & D \\
\hline
\end{tabular}


Table 2. Surface-water stations operated by the Illinois District for which data are published - Continued

\begin{tabular}{|c|c|c|}
\hline $\begin{array}{c}\text { Station } \\
\text { Number }\end{array}$ & Station name & $\begin{array}{c}\text { Type of } \\
\text { data }\end{array}$ \\
\hline 05540160 & East Branch Du Page River near Downers Grove, Ill. & $\mathrm{D}$ \\
\hline 05540195 & St. Joseph Creek at Route 34 at Lisle, Ill. & $\mathrm{D}$ \\
\hline 05540250 & East Branch Du Page River at Bolingbrook, Ill. & $\mathrm{D}$ \\
\hline 05540275 & Spring Brook at 87 th Street near Naperville, Ill. & $\mathrm{D}, \mathrm{CQ}$ \\
\hline 05540500 & Du Page River at Shorewood, Ill. & $\mathrm{D}$ \\
\hline 05542000 & Mazon River near Coal City, Ill. & D \\
\hline 05543500 & Illinois River at Marseilles, Ill. & $\mathrm{D}, \mathrm{CQ}$ \\
\hline 05547000 & Channel Lake near Antioch, Ill. & $\mathrm{S}$ \\
\hline 05547500 & Fox Lake near Lake Villa, III. & $\mathrm{S}$ \\
\hline 05547755 & Squaw Creek at Round Lake, Ill. & $\mathrm{D}$ \\
\hline 05548000 & Nippersink Lake at Fox Lake, Ill. & $\mathrm{S}$ \\
\hline 05548280 & Nippersink Creek near Spring Grove, Ill. & $\mathrm{D}$ \\
\hline 05548500 & Fox River at Johnsburg, Ill. & $\mathrm{S}$ \\
\hline 05549500 & Fox River near McHenry, Ill. & $\mathrm{S}$ \\
\hline 05549850 & Flint Creek near Fox River Grove, Ill. & $\mathrm{D}$ \\
\hline 05550000 & Fox River at Algonquin, Ill. & $\mathrm{D}$ \\
\hline 05550500 & Poplar Creek at Elgin, Ill. & $\mathrm{D}$ \\
\hline 05551000 & Fox River at South Elgin, Ill. & $\mathrm{D}$ \\
\hline 05551200 & Ferson Creek near St. Charles, III. & $\mathrm{D}$ \\
\hline 05551700 & Blackberry Creek near Yorkville, III. & $\mathrm{D}$ \\
\hline 05552500 & Fox River at Dayton, Ill. & D \\
\hline 05554000 & North Fork Vermilion River near Charlotte, Ill. & $\mathrm{C}$ \\
\hline 05554500 & Vermilion River at Pontiac, Ill. & $\mathrm{D}$ \\
\hline 05555300 & Vermilion River near Leonore, Ill. & $\mathrm{D}$ \\
\hline 05556500 & Big Bureau Creek at Princeton, Ill. & $\mathrm{D}$ \\
\hline 05557500 & East Bureau Creek near Bureau, Ill. & $\mathrm{C}$ \\
\hline 05558300 & Illinois River at Henry, Ill. & $\mathrm{D}$ \\
\hline 05559600 & Illinois River at Chillicothe, Ill. & SD \\
\hline 05563000 & Kickapoo Creek near Kickapoo, Ill. & $\mathrm{C}$ \\
\hline 05563500 & Kickapoo Creek at Peoria, III. & $\mathrm{C}$ \\
\hline 05567000 & Panther Creek near El Paso, III. & C \\
\hline 05567500 & Mackinaw River near Congerville, Ill. & $\mathrm{D}$ \\
\hline 05568000 & Mackinaw River near Green Valley, Ill. & $\mathrm{D}$ \\
\hline 05568500 & Illinois River at Kingston Mines, Ill. & DS \\
\hline 05568800 & Indian Creek near Wyoming, III. & $\mathrm{D}$ \\
\hline 05569500 & Spoon River at London Mills, Ill. & $\mathrm{D}$ \\
\hline 05570000 & Spoon River at Seville, III. & $\mathrm{D}, \mathrm{CQ}$ \\
\hline 05570910 & Sangamon River at Fisher, Ill. & D \\
\hline 05572000 & Sangamon River at Monticello, III. & $\mathrm{D}$ \\
\hline 05573540 & Sangamon River at Route 48 at Decatur, Ill. & $\mathrm{D}$ \\
\hline 05576000 & South Fork Sangamon River near Rochester, Ill. & DS \\
\hline 05576500 & Sangamon River at Riverton, Ill. & $\mathrm{D}$ \\
\hline 05577500 & Spring Creek at Springfield, III. & $\mathrm{D}$ \\
\hline 05578500 & Salt Creek near Rowell, IIl. & $\mathrm{D}$ \\
\hline 05579500 & Lake Fork near Cornland, Ill. & $\mathrm{D}$ \\
\hline
\end{tabular}


Table 2. Surface-water stations operated by the Illinois District for which data are published - Continued

\begin{tabular}{|c|c|c|}
\hline $\begin{array}{c}\text { Station } \\
\text { Number } \\
\end{array}$ & Station name & $\begin{array}{c}\text { Type of } \\
\text { data }\end{array}$ \\
\hline 05580000 & Kickapoo Creek at Waynesville, Ill. & D \\
\hline 05580950 & Sugar Creek near Bloomington, Ill. & $\mathrm{D}$ \\
\hline 05582000 & Salt Creek near Greenview, Ill. & D \\
\hline 05583000 & Sangamon River near Oakford, Ill. & $\mathrm{D}, \mathrm{CQ}$ \\
\hline 05584500 & La Moine River at Colmar, Ill. & D \\
\hline 05585000 & La Moine River at Ripley, Ill. & D \\
\hline 05585500 & Illinois River at Meredosia, Ill. & $\mathrm{S} / 8$ \\
\hline 05586000 & North Fork Mauvaise Terre Creek near Jacksonville, Ill. & C \\
\hline 05586100 & Illinois River at Valley City, Ill. & $\mathrm{D}, \mathrm{CQ}, \mathrm{SD}$ \\
\hline 05586500 & Hurricane Creek near Roodhouse, Ill. & C \\
\hline 05587000 & Macoupin Creek near Kane, Ill. & $\mathrm{D}$ \\
\hline 05587060 & Illinois River at Hardin, Ill. & $\mathrm{S} / 8$ \\
\hline 05587900 & Cahokia Creek at Edwardsville, Ill. & $\mathrm{D}$ \\
\hline 05588000 & Indian Creek at Wanda, Ill. & $\mathrm{D}$ \\
\hline 05590800 & Lake Fork at Atwood, Ill. & D \\
\hline 05591200 & Kaskaskia River at Cooks Mills, Ill. & $\mathrm{D}, \mathrm{SD}$ \\
\hline 05591550 & Whitley Creek near Allenville, Ill. & $\mathrm{D}$ \\
\hline 05591700 & West Okaw River near Lovington, Ill. & $\mathrm{D}$ \\
\hline 05591950 & Lake Shelbyville near Shelbyville, Ill. & $\mathbf{R}$ \\
\hline 05592000 & Kaskaskia River at Shelbyville, Ill. & $\mathrm{D}$ \\
\hline 05592050 & Robinson Creek near Shelbyville, Ill. & D \\
\hline 05592100 & Kaskaskia River near Cowden, Ill. & $\mathrm{D}$ \\
\hline 05592500 & Kaskaskia River at Vandalia, Ill. & D \\
\hline 05592575 & Hickory Creek near Brownstown, Ill. & $\mathrm{D}$ \\
\hline 05592800 & Hurricane Creek near Mulberry Grove, Ill. & $\mathrm{D}$ \\
\hline 05592900 & East Fork Kaskaskia River near Sandoval, Ill. & D \\
\hline 05592990 & Carlyle Lake near Carlyle, Ill. & $\mathbf{R}$ \\
\hline 05593000 & Kaskaskia River at Carlyle, Ill. & D \\
\hline 05593520 & Crooked Creek near Hoffman, Ill. & D \\
\hline 05593575 & Little Crooked Creek near New Minden, Ill. & $\mathrm{D}$ \\
\hline 05593900 & East Fork Shoal Creek near Coffeen, Ill. & D \\
\hline 05594000 & Shoal Creek near Breese, IIl. & $\mathrm{D}$ \\
\hline 05594100 & Kaskaskia River near Venedy Station, Ill. & $\mathrm{D}, \mathrm{SD}$ \\
\hline 05594450 & Silver Creek near Troy, Ill. & $\mathrm{D}$ \\
\hline 05594800 & Silver Creek near Freeburg, Ill. & $\mathrm{D}, \mathrm{S} / 8$ \\
\hline 05595200 & Richland Creek near Hecker, Ill. & $\mathrm{D}, \mathrm{S} / 8$ \\
\hline 05595700 & Big Muddy River near Mt. Vernon, Ill. & $\mathrm{S}$ \\
\hline 05595730 & Rayse Creek near Waltonville, Ill. & $\mathrm{D}, \mathrm{S} / 8$ \\
\hline 05595765 & Big Muddy Subimpoundment near Waltonville, Ill. & $\mathrm{S} / 8$ \\
\hline 05595820 & Casey Fork at Mt. Vernon, Ill. & $\mathrm{D}, \mathrm{S} / 8$ \\
\hline 05595860 & Casey Fork Subimpoundment near Bonnie, Ill. & $\mathrm{S} / 8$ \\
\hline 05595950 & Rend Lake near Benton, Ill. & $\mathbf{R}$ \\
\hline 05597000 & Big Muddy River at Plumfield, Ill. & DS \\
\hline 05597500 & Crab Orchard Creek near Marion, III. & D \\
\hline 05599500 & Big Muddy River at Murphysboro, Ill. & DS,SD \\
\hline 05600000 & Big Creek near Wetaug, Ill. & $\mathrm{C}$ \\
\hline
\end{tabular}


Table 3. Discontinued surface-water-discharge or stage-only stations operated by the Illinois District for which data were published

[d, discharge; e, elevation (stage only); $\mathrm{mi}^{2}$, square miles; --, not determined]

The following continuous-record surface-water-discharge or stage-only stations (gaging stations) in Illinois have been discontinued. Daily streamflow or stage records were collected and published for the period of record, expressed in water years, shown for each station. Those stations with an asterisk $\left(^{*}\right)$ after the station number are currently operated as crest-stage partial-record stations. Discontinued project stations with less than 3 years of record have not been included. Information regarding these stations may be obtained from the District office at the address given on the back side of the title page of this report.

\begin{tabular}{|c|c|c|c|c|}
\hline Station name & $\begin{array}{c}\text { Type of } \\
\text { data }\end{array}$ & $\begin{array}{l}\text { Station } \\
\text { number }\end{array}$ & $\begin{array}{c}\text { Drainage } \\
\text { area } \\
\left(\mathbf{m i}^{\mathbf{2}}\right)\end{array}$ & $\begin{array}{l}\text { Period } \\
\text { of } \\
\text { record }\end{array}$ \\
\hline
\end{tabular}

Bluegrass Creek at Potomac, III.

Salt Fork near St. Joseph, Ill.

Saline Branch at Urbana, Ill.

Salt Fork near Homer, Ill.

Vermilion River near Catlin, Ill.

Embarras River near Oakland, Ill.

Embarras River at State Highway 133 near Oakland, Ill.

Embarras River near Diona, Ill.

Range Creek near Casey, Ill.

Embarras River near Newton, Ill.

Embarras River at Lawrenceville, III.

Little Wabash River at Louisville, Ill.

Little Wabash River near Clay City, Ill.

Little Wabash River at Blood, Ill.

Little Wabash River near Golden Gate, Ill.

Skillet Fork near Iuka, Ill.

Horse Creek near Keenes, Ill.

Skillet Fork near Mill Shoals, Ill.

Brushy Creek near Harco, Ill.

Middle Fork Saline River near Harrisburg, Ill.

North Fork Saline River near Ridgway, Ill.

Saline River near Junction, Ill.

Eagle Creek near Equality, Ill.

Hayes Creek at Glendale, Ill.

Lake Glendale Inlet near Dixon Springs, III.

Lake Glendale Outlet near Dixon Springs, Ill.

Sugar Creek near Dixon Springs, Ill.

\section{OHIO RIVER BASIN}

Wabash River Basin

Vermilion River Basin

d
$d$
$d$
$d$
$d$

Embarras River Basin

d

d

d

d

d

d

Little Wabash River Basin

03344500

03345000

03346500

03336500

03337500

03338000

03338500

03343500
03343550
03344000

518

542

919

35.0

134

68.0

340

959

1950-71

1959-91

1936-58

1945-58

1940-58
1910-15

1979-82

1939-40, 1944-47, 1971-82 1951-82 1939-45 1930-34

$\begin{array}{ll}7.61 & 1951-82 \\ 1,392 & 1939-45 \\ 2,333 & 1930-34\end{array}$

$\begin{array}{cc}745 & 1965-82 \\ 801 & 1909-13 \\ 1,387 & 1973-82 \\ 1,792 & 1908-13 \\ & 1973-80 \\ 208 & 1966-82 \\ 97.2 & 1959-90 \\ 874 & 1909-13 \\ & 1975-78\end{array}$

$\begin{array}{cc}\text { River Basin } & \\ \text { d } & 03378900 \\ \text { e } & 03379000 \\ \text { e } & 03379600 \\ \text { e } & 03380000 \\ & \\ \text { d } & 03380350 \\ \text { d } & 03380475 \\ \text { e } & 03381000\end{array}$

Saline River Basin

d
d
$d$
$d$
$d$

\section{Bay Creek Basin}

$\begin{array}{ll}\text { d } & 03385000^{*} \\ \text { d } & 03385500 \\ \text { d } & 03386000 \\ d & 03386500\end{array}$

$\begin{array}{ccc}03382170 & 13.3 & 1968-82 \\ 03382200 & 225 & 1924-32 \\ 03382350 & 423 & 1965-69 \\ 03382500 & 1,051 & 1940-71 \\ 03382510 & 8.51 & 1966-82\end{array}$


Table 3. Discontinued surface-water-discharge or stage-only stations operated by the Illinois District for which data were published-Continued

\begin{tabular}{ccccc}
\hline & Type of \\
data & Station name & $\begin{array}{c}\text { Station } \\
\text { number }\end{array}$ & $\begin{array}{c}\text { Drainage } \\
\text { area } \\
\left(\mathbf{m i}^{2}\right)\end{array}$ & $\begin{array}{c}\text { Period } \\
\text { of } \\
\text { record }\end{array}$ \\
\hline
\end{tabular}

GREAT LAKES BASIN

Streams Tributary to Lake Michigan

Wolf Lake at Chicago, Ill.

e $\quad 04092500$

$1940-82$

\section{UPPER MISSISSIPPI RIVER BASIN ABOVE THE ILLINOIS RIVER}

Galena River at Galena, III.

Galena River Basin

$\begin{array}{llll}\text { d } & 05416000 & 196 & 1935-38, \\ \text { e } & & & 1939\end{array}$

Plum River Basin

Plum River near Savanna, Ill.

Plum River below Carroll Creek near Savanna, Ill.

$\begin{array}{llll}\text { d } & 05419500 & 162 & 1935-41 \\ \text { d } & 05420000 & 230 & 1941-77\end{array}$

Cedar Creek near Winslow, Ill.

Pecatonica River at Shirland, III.

Coon Creek at Riley, Ill.

Killbuck Creek near Monroe Center, Ill.

Leaf River at Leaf River, Ill.

Rock River at Oregon, III.

Kyte River near Flagg Center, Ill.

Rock Creek near Coleta, Ill.

Rock Creek near Morrison, III.

Rock Creek at Morrison, Ill.

Green River at Amboy, Ill.

Henderson Creek near Little York, Ill.

North Henderson Creek near Seaton, Ill.

Cedar Creek at Little York, Ill.

South Henderson Creek at Biggsville, Ill.

Hadley Creek near Barry, Ill.

Hadley Creek at Kinderhook, Ill.

Hadley Creek near Shinn, Ill.

\section{Rock River Basin}

$\begin{array}{lccc}\text { d } & 05435000 & 1.31 & 1951-71 \\ \text { d } & 05437000 & 2,550 & 1940-58 \\ \text { d } & 05438250 & 85.1 & 1961-82 \\ \text { d } & 05440500 & 117 & 1940-71 \\ \text { d } & 05441000 & 103 & 1940-58 \\ \text { d } & 05441500 & 8,205 & 1940-49 \\ \text { d } & 05442000 & 116 & 1940-51 \\ \text { d } & 05445000 & 82.8 & 1040-42 \\ \text { d } & 05445500 & 158 & 1943-58 \\ \text { d } & 05446000^{*} & 164 & 1940-42, \\ & & & 1978-86 \\ \text { d } & 05447000 & 201 & 1940-58\end{array}$

Henderson Creek Basin

$\begin{array}{lccc}\text { d } & 05467500 & 151 & 1941-58 \\ \text { d } & 05468000 & 67.1 & 1941-51 \\ \text { d } & 05468500 & 132 & 1941-71 \\ \text { d } & 05469500 & 82.9 & 1940-71\end{array}$

Hadley Creek Basin

$\begin{array}{ll}\mathrm{d} & 05502020 \\ \mathrm{~d} & 05502040\end{array}$

$40.9 \quad 1956-66$

$72.7 \quad 1940-86$

$73.6 \quad 1941-46$

The Sny Basin

$\begin{array}{llll}\text { d } & 05512000 & 451 & 1940-42\end{array}$

Bay Creek Basin

Bay Creek at Nebo, Ill.

\section{ILLINOIS RIVER BASIN \\ Kankakee River Basin}

Terry Creek near Custer Park, Ill.

Kankakee River at Custer Park, III.

$\begin{array}{ll}\text { d } & 05526500 \\ \text { d } & 05527000\end{array}$

12.1

1949-75

4,810

1915-34 
Table 3. Discontinued surface-water-discharge or stage-only stations operated by the Illinois District for which data were published-Continued

\begin{tabular}{|c|c|c|c|c|}
\hline Station name & $\begin{array}{c}\text { Type of } \\
\text { data }\end{array}$ & $\begin{array}{c}\text { Station } \\
\text { number }\end{array}$ & $\begin{array}{c}\text { Drainage } \\
\text { area } \\
\left(\mathbf{m i}^{2}\right) \\
\end{array}$ & $\begin{array}{c}\text { Period } \\
\text { of } \\
\text { record }\end{array}$ \\
\hline \multicolumn{5}{|c|}{ Des Plaines River Basin } \\
\hline Willow Creek near Park Ridge, Ill. & $\mathrm{d}$ & 05530500 & 19.7 & $1950-58$ \\
\hline Salt Creek near Arlington Heights, Ill. & $\mathrm{d}$ & 05531000 & 32.1 & $\begin{array}{l}1950-71, \\
1973\end{array}$ \\
\hline Des Plaines River at Lemont, Ill. & d & 05533500 & 684 & 1915-44 \\
\hline Thorn Creek near Chicago Heights, Ill. & $\mathrm{d}$ & 05536210 & 17.2 & 1964-79 \\
\hline North Creek near Lansing, Ill. & $\mathrm{d}$ & 05536270 & 16.8 & 1948-79 \\
\hline Little Calumet River at Harvey, Ill. & $\mathrm{d}$ & 05536325 & 252 & 1917-33 \\
\hline Chicago Sanitary and Ship Canal at Lockport, Ill. & d & 05537000 & 740 & $1900-84$ \\
\hline Des Plaines River at Joliet, Ill. & $\mathrm{d}$ & 05538000 & 1,503 & $1915-32$ \\
\hline Soring Creek at Joliet. Ill. & d & 05538500 & 19.6 & $1925-35$ \\
\hline
\end{tabular}

Spring Creek at Joliet, Ill.

\section{Du Page River Basin}

d

05540200

\section{Fox River Basin}

d

Vermilion River Basin

North Fork Vermilion River near Charlotte, Ill.

Vermilion River at Streator, III.

Vermilion River at Lowell, Ill.

West Bureau Creek at Wyanet, III.

East Bureau Creek near Bureau, IIl.

Big Bureau Creek at Bureau, Ill.

Crow Creek (West) near Henry, III.

Gimlet Creek at Sparland, Ill.

Crow Creek near Washburn, Ill.

Illinois River at Peoria, Ill.

Farm Creek at Farmdale, III.

Ackerman Creek at Farmdale, Ill.

Fondulac Creek near East Peoria, III.

Farm Creek at East Peoria, Ill.

Kickapoo Creek near Kickapoo, Ill.

Kickapoo Creek at Peoria, Ill.

d
d
d

Big Bureau Creek Basin

$\begin{array}{ll}\text { d } & 05557000 \\ \text { d } & 05557500^{*} \\ \text { d } & 05558000\end{array}$

Crow Creek (West) Basin

d 05558500

56.2

1949-71

\section{Gimlet Creek Basin}

d

05559000

Crow Creek Basin

d

05559500

115

\section{Illinois River Main Stem}

d

05560000

14,165

5.66

1946-47, 1951-71

1945-71

1903-06, 1910-39

Farm Creek Basin

$\mathrm{d}$
$\mathrm{d}$
$\mathrm{d}$
$\mathrm{d}$

05560500

05561000

05561500

05562000

Kickapoo Creek Basin

$\begin{array}{ll}\text { d } & 05563000^{*} \\ \text { d } & 05563500^{*}\end{array}$

$\begin{array}{cc}27.4 & 1949-85 \\ 11.2 & 1954-80 \\ 5.54 & 1948-85 \\ 61.2 & 1943-80 \\ & \\ 119 & 1945-62 \\ 297 & 1942-71\end{array}$


Table 3. Discontinued surface-water-discharge or stage-only stations operated by the Illinois District for which data were published-Continued

\begin{tabular}{l} 
Station name \\
\hline \\
Money Creek near Towanda, Ill. \\
Money Creek above Lake Bloomington, Ill. \\
Hickory Creek above Lake Bloomington, Ill. \\
Money Creek at Lake Bloomington, Ill. \\
East Branch Panther Creek near Gridley, Ill. \\
East Branch Panther Creek at El Paso, Ill. \\
Panther Creek near El Paso, Ill. \\
Brush Creek at Lake Bracken near Galesburg, III. \\
Big Creek at St. David, Ill. \\
Evelyn Branch near Bryant, Ill. \\
Big Creek near Bryant, Ill. \\
Slug Run near Bryant, Ill.
\end{tabular}

Illinois River at Havana, IIl.

Sangamon River at Mahomet, Ill.

Goose Creek near De Land, Ill.

Friends Creek at Argenta, III.

Sangamon River near Oakley, Ill.

South Fork Sangamon River near Nokomis, III.

Flat Branch near Taylorville, Ill.

South Fork Sangamon River near Taylorville, III.

South Fork Sangamon River at Kincaid, Ill.

Horse Creek at Pawnee, Ill.

Brush Creek near Divernon, III.

Salt Creek near Kenney, Ill.

Kickapoo Creek near Lincoln, III.

Sugar Creek near Hartsburg, Ill.

Crane Creek near Easton, Ill.

Illinois River at Beardstown, Ill.

Drowning Fork at Bushnell, Ill.

Illinois River at Meredosia, Ill.

\section{Mackinaw River Basin}

$\begin{array}{cccc}\text { d } & 05564400 & 49.0 & 1958-82 \\ \text { d } & 05564500 & 53.1 & 1933-58 \\ \text { d } & 05565000 & 9.81 & 1939-58 \\ \text { d } & 05565500 & 69.1 & 1931-58 \\ \text { d } & 05566000 & 6.30 & 1950-60 \\ \text { d } & 05566500 & 30.5 & 1950-82 \\ \text { d } & 05567000^{*} & 93.9 & 1950-60\end{array}$

Spoon River Basin

$\begin{array}{ll}\text { d } & 05569000 \\ \text { d } & 05570350 \\ \text { d } & 05570360 \\ \text { d } & 05570370 \\ \text { d } & 05570380\end{array}$

$\begin{array}{cc}9.11 & 1932-58 \\ 28.0 & 1972-86 \\ 5.78 & 1972-92 \\ 41.2 & 1972-92 \\ 7.12 & 1975-92\end{array}$

Illinois River Main Stem

d

05570500

18,299

1922-27, 1985-89

\section{Sangamon River Basin}

d
$d$
$d$
$d$
$d$
$d$
$d$
$d$
d
d
d
d
d
d

05571000
05571500
05572450
05572500
05574000
05574500
05575000
05575500
05575800
05575830
05579000
05580500
05581500
05582500

362

47.9

111

774

11.0

276

434

562

\section{2}

32.4

390

306

333

26.5

1948-78

1951-59

1967-82

1951-77

1951-75

1949-82

1908-17

1917-34, 1945-61

1968-85

1974-82

1908-13

1945-71

1945-71

1950-75

\section{Illinois River Main Stem}

d

05584000

24,277

1921-38

La Moine River Basin

d

05584400

26.3

1960-82

\section{Illinois River Main Stem}

d

05585500

26,028

1939-89

Mauvaise Terre Creek Basin

North Fork Mauvaise Terre Creek near Jacksonville, Ill.

$05586000^{*}$

29.1

$1950-75$ 
Table 3. Discontinued surface-water-discharge or stage-only stations operated by the Illinois District for which data were published-Continued

\begin{tabular}{|c|c|c|c|c|}
\hline Station name & $\begin{array}{c}\text { Type of } \\
\text { data }\end{array}$ & $\begin{array}{l}\text { Station } \\
\text { number }\end{array}$ & $\begin{array}{c}\text { Drainage } \\
\text { area } \\
\left(\mathbf{m i}^{2}\right)\end{array}$ & $\begin{array}{c}\text { Period } \\
\text { of } \\
\text { record }\end{array}$ \\
\hline \multicolumn{5}{|c|}{ Hurricane Creek Basin } \\
\hline Hurricane Creek near Roodhouse, Ill. & d & $05586500^{*}$ & 2.30 & $1951-75$ \\
\hline \multicolumn{5}{|c|}{ Macoupin Creek Basin } \\
\hline Otter Creek near Palmyra, IIl. & d & 05586800 & 61.1 & $1960-80$ \\
\hline
\end{tabular}

\section{UPPER MISSISSIPPI RIVER BASIN BELOW THE ILLINOIS RIVER} Cahokia Canal Basin

Long Lake at Stallings, Ill.

Canteen Creek at Caseyville, III.

d

d

Kaskaskia River Basin

Kaskaskia Ditch at Bondville, Ill.

Kaskaskia River near Pesotum, Ill.

Kaskaskia River at Ficklin, Ill.

Kaskaskia River near Arcola, Ill.

Asa Creek at Sullivan, Ill.

Wolf Creek near Beecher City, Ill.

Hickory Creek near Bluff City, III

Martin Branch near Centralia, III.

Crooked Creek near Posey, III.

Blue Grass Creek near Raymond, III.

Sugar Creek at Albers, Ill.

Mud Creek near Marissa, Ill.

Silver Creek near Lebanon, Ill.

Kaskaskia River at New Athens, Ill.

Marys River near Sparta, Ill.

Sevenmile Creek near Mt. Vernon, Ill.

Casey Fork at Route 37 near Mt. Vernon, Ill.

Big Muddy River near Benton, Ill.

Tilley Creek near West Frankfort, IIl.

Crab Orchard Lake near Carterville, III.

Beaucoup Creek near Pinckneyville, III.

Beaucoup Creek near Matthews, Ill.

Big Creek near Wetaug, Ill.

$\begin{array}{ll}\text { d } & 05590000 \\ \text { d } & 05590400 \\ \text { d } & 05590500 \\ \text { d } & 05591000 \\ \text { d } & 05591500 \\ \text { d } & 05592300 \\ \text { e } & 05592600 \\ \text { d } & 05593500 \\ & \\ \text { d } & 05593525 \\ \text { d } & 05593600 \\ \text { d } & 05594090 \\ \text { d } & 05594330 \\ \text { d } & 05594500 \\ \text { d } & 05595000\end{array}$

e

Marys River Basin

d

05595500

17.8

1949-71

Big Muddy River Basin

$\begin{array}{ll}\text { d } & 05595800 \\ \text { e } & 05595830 \\ \text { d } & 05596000 \\ \text { d } & 05596500 \\ & \\ \text { e } & 05598000 \\ \text { d } & 05598500 \\ \text { d } & 05599000\end{array}$

21.1

1961-82

$87.7 \quad 1980-85$

$502 \quad 1946-70$

3.87 1939-46,

1949-55

1953-79

$-$

1909-15

1946-82

Cache River Basin

05600000*

32.2

1941-71 
Table 4. Discontinued surface-water-quality and sediment stations operated by the Illinois District for which data were published

[c, chemical; $b$, biological; and $\mathrm{m}$, microbiological are all periodic records; $t$, temperature; sc, specific conductance; and s, sediment are all continuous records; $\mathrm{mi}^{2}$, square miles; --, not determined]

The following are discontinued stations for which continuous records or periodic (collection frequency not less than quarterly) records of surface-water quality were published. The period of record for each type of data collected is expressed in water years. Discontinued project stations with short periods of record have not been included.

\begin{tabular}{|c|c|c|c|c|}
\hline Station name & $\begin{array}{c}\text { Type of } \\
\text { data }\end{array}$ & $\begin{array}{l}\text { Station } \\
\text { number }\end{array}$ & $\begin{array}{c}\text { Drainage } \\
\text { area } \\
\left(\mathbf{m i}^{\mathbf{2}}\right)\end{array}$ & $\begin{array}{c}\text { Period } \\
\text { of } \\
\text { record }\end{array}$ \\
\hline \multicolumn{5}{|c|}{$\begin{array}{l}\text { OHIO RIVER BASIN } \\
\text { Wabash River } \\
\text { Vermilion River Basin }\end{array}$} \\
\hline Middle Fork Vermilion River above Oakwood, Ill. & $\begin{array}{l}\mathrm{c}, \mathrm{m} \\
\mathrm{sc}, \mathrm{t}\end{array}$ & 03336645 & 432 & $\begin{array}{l}1978-91 \\
1979\end{array}$ \\
\hline Salt Fork near St. Joseph, Ill. & $\mathrm{c}, \mathrm{m}$ & 03336900 & 134 & $\begin{array}{l}1959-62 \\
1978-91\end{array}$ \\
\hline Saline Branch near Mayview, Ill. & $\mathrm{c}, \mathrm{m}$ & 03337700 & 82.1 & $1978-90$ \\
\hline Salt Fork near Oakwood, Ill. & $\mathrm{c}, \mathrm{m}$ & 03338097 & 489 & $1978-90$ \\
\hline North Fork Vermilion River near Bismarck, Ill. & $\mathrm{c}, \mathrm{m}$ & 03338780 & 262 & $1978-91$ \\
\hline Vermilion River near Danville, Ill. & $\mathrm{c}, \mathrm{m}$ & 03339000 & 1,290 & $\begin{array}{l}1906-07 \\
1978-91\end{array}$ \\
\hline Little Vermilion River near Georgetown, Ill. & $\mathrm{c}, \mathrm{m}$ & 03339147 & 191 & $1979-90$ \\
\hline \multicolumn{5}{|c|}{ Brouilletts Creek Basin } \\
\hline Brouilletts Creek near St. Bernice, Ind. & $\mathrm{c}, \mathrm{m}$ & 03341414 & 260 & $1978-90$ \\
\hline \multicolumn{5}{|c|}{ Sugar Creek Basin } \\
\hline Sugar Creek near Elbridge, Ill. & $\mathrm{c}, \mathrm{m}$ & 03341540 & 61.0 & $1978-90$ \\
\hline \multicolumn{5}{|c|}{ Wabash River Main Stem } \\
\hline Wabash River at Hutsonville, Ill. & c & 03341920 & 12,986 & $\begin{array}{l}1969-73, \\
1978-91\end{array}$ \\
\hline \multicolumn{5}{|c|}{ Sugar Creek Basin } \\
\hline Sugar Creek at Palestine, Ill. & $\mathrm{c}, \mathrm{m}$ & 03342050 & 35.8 & 1979-87 \\
\hline \multicolumn{5}{|c|}{ Embarras River Basin } \\
\hline Embarras River at Camargo, III. & $\mathrm{c}, \mathrm{m}$ & 03343395 & 180 & $1978-91$ \\
\hline Embarras River at State Highway 133 near Oakland, Ill. & $\mathbf{s}$ & 03343550 & 542 & 1979-82 \\
\hline \multirow[t]{2}{*}{ Embarras River near Diona, Ill. } & $\mathrm{c}, \mathrm{m}$ & 03344000 & 919 & $\begin{array}{l}1971-76 \\
1978-91\end{array}$ \\
\hline & $\mathrm{sc}, \mathrm{t}$ & & & $1971-76$ \\
\hline North Fork Embarras River near Oblong, Ill. & $\mathrm{c}$ & 03346000 & 319 & $1978-91$ \\
\hline Embarras River near Billett, Ill. & $\mathrm{c}, \mathrm{m}$ & 03346550 & 2,403 & $1978-87$ \\
\hline \multicolumn{5}{|c|}{ Bonpas Creek Basin } \\
\hline Bonpas Creek at Browns, Ill. & $\mathrm{c}, \mathrm{m}$ & 03378000 & 228 & $1978-91$ \\
\hline
\end{tabular}


Table 4. Discontinued surface-water-quality and sediment stations operated by the Illinois District for which data were published-Continued

\begin{tabular}{|c|c|c|c|c|}
\hline Station name & $\begin{array}{c}\text { Type of } \\
\text { data }\end{array}$ & $\begin{array}{l}\text { Station } \\
\text { number }\end{array}$ & $\begin{array}{c}\text { Drainage } \\
\text { area } \\
\left(\mathbf{m i}^{\mathbf{2}}\right) \\
\end{array}$ & $\begin{array}{c}\text { Period } \\
\text { of } \\
\text { record }\end{array}$ \\
\hline \multicolumn{5}{|c|}{ Little Wabash River Basin } \\
\hline Little Wabash River near Effingham, Ill. & $\mathrm{c}, \mathrm{m}$ & 03378635 & 240 & $1979-91$ \\
\hline \multirow[t]{3}{*}{ Little Wabash River at Louisville, Ill. } & $\mathrm{c}, \mathrm{m}$ & 03378900 & 745 & $1971-91$ \\
\hline & $\mathrm{sc}, \mathrm{t}$ & & & $1971-79$ \\
\hline & $\mathbf{s}$ & & & $1977-81$ \\
\hline Little Wabash River below Clay City, Ill. & $\mathrm{c}, \mathrm{m}$ & 03379500 & 1,131 & $1979-91$ \\
\hline Little Wabash River at Blood, Ill. & $\mathrm{c}, \mathrm{m}$ & 03379600 & 1,387 & $1978-90$ \\
\hline Elm River near Toms Prairie, Ill. & $c, m$ & 03379950 & 265 & $1979-87$ \\
\hline \multirow[t]{3}{*}{ Skillet Fork near Iuka, Ill. } & $\mathrm{c}, \mathrm{m}$ & 03380350 & 208 & 1974-76, \\
\hline & & & & $1979-87$ \\
\hline & $\mathbf{s c}, \mathrm{t}$ & & & 1973-76, \\
\hline \multirow[t]{2}{*}{ Skillet Fork at Wayne City, Ill. } & $\mathrm{c}, \mathrm{m}$ & 03380500 & 464 & $1978-91$ \\
\hline & $\mathrm{sc}, \mathrm{t}$ & & & 1979 \\
\hline Skillet Fork near Carmi, Ill. & $\mathrm{c}, \mathrm{m}$ & 03381400 & 1,058 & $1978-87$ \\
\hline Little Wabash River at Carmi, Ill. & $\mathrm{c}, \mathrm{b}, \mathrm{m}, \mathrm{sc}, \mathrm{t}$ & 03381500 & 3,102 & 1978-79 \\
\hline
\end{tabular}

Ohio River at Old Shawneetown, III.

Ohio River Ohio River Main Stem

$\mathrm{t}$

03381700

Saline River Basin

South Fork Saline River near Crab Orchard, III. Sugar Creek near Stonefort, Ill.

South Fork Saline River near Carrier Mills, Ill.

Brushy Creek near Harco, Ill.

Bankston Fork near Dorris Heights, Ill.

Middle Fork Saline River near Pankeyville, Ill.

North Fork Saline River near Texas City, Ill.

Saline River near Gibsonia, III.

Lusk Creek near Eddyville, Ill.

Cache River at Forman, Ill.

Calumet River at Chicago, Ill.

Lake Michigan at Calumet Park at Chicago, Ill.

$\begin{array}{cccl}\mathrm{c}, \mathrm{m} & 03382055 & 83.2 & 1983-87 \\ \mathrm{c}, \mathrm{m} & 03382090 & 35.4 & 1978-88 \\ \mathrm{c} & 03382100 & 147 & 1977-91 \\ \mathrm{sc}, \mathrm{t}, \mathrm{s} & & & 1980-81 \\ \mathrm{c}, \mathrm{sc}, \mathrm{s} & 03382170 & 13.3 & 1980-81 \\ \mathrm{t} & & & 1980 \\ \mathrm{c}, \mathrm{m} & 03382185 & 77.7 & 1979-87 \\ \mathrm{c}, \mathrm{m} & 03382205 & 233 & 1978-87 \\ \mathrm{c}, \mathrm{m} & 03382325 & 249 & 1978-87 \\ \mathrm{c}, \mathrm{m} & 03382530 & 1,062 & 1978-87\end{array}$

Lusk Creek Basin

$\begin{array}{cccc}\mathrm{c}, \mathrm{m} & 03384450 & 42.9 & 1978-91 \\ \mathrm{sc}, \mathrm{t}, \mathrm{s} & & & 1980-81\end{array}$

Cache River Basin

$\begin{array}{lll}c, m & 03612000 & 244\end{array}$

1978-91

\section{GREAT LAKES BASIN}

Streams Tributary to Lake Michigan

Lake Michigan

04092490

1974-77

$\mathrm{t} \quad 04092550$

$-$

1974-77 
Table 4. Discontinued surface-water-quality and sediment stations operated by the Illinois District for which data were published-Continued

\begin{tabular}{|c|c|c|c|c|}
\hline Station name & $\begin{array}{c}\text { Type of } \\
\text { data }\end{array}$ & $\begin{array}{c}\text { Station } \\
\text { number }\end{array}$ & $\begin{array}{c}\text { Drainage } \\
\text { area } \\
\left(\mathbf{m i}^{2}\right)\end{array}$ & $\begin{array}{l}\text { Period } \\
\text { of } \\
\text { record }\end{array}$ \\
\hline
\end{tabular}

\section{UPPER MISSISSIPPI RIVER BASIN ABOVE THE ILLINOIS RIVER} Galena River Basin

Galena River at Galena, Ill.

Apple River near Elizabeth, Ill.

Plum River at Savanna, Ill. $\mathrm{c}, \mathrm{m}$

Apple River Basin

$\mathrm{c}, \mathrm{m}$

05418950

207

273

$1978-90$

Mississippi River at Dam 13 near Fulton, Ill.

Mississippi River at Dam 14 near Hampton, Ill.

\section{Mississippi River Main Stem}

05420400

85,600

$05422400 \quad 88,400$

1969-77

1973-77

Pecatonica River at Freeport, III.

Rock River Basin

Pecatonica River Basin

Yellow Creek near Freeport, Ill.

$\mathrm{c}, \mathrm{m}$

05435500

05435680

1,326

$\mathrm{c}, \mathrm{m}$

$\mathrm{c}, \mathrm{m}$

05435800

192

1,788

1978-91

1979-87

Pecatonica River at Harrison, Ill.

Rock River Main Stem

Rock River at Rockton, Ill. $c, m$

05437500

6,363

1978-91

Kishwaukee River Basin

Kishwaukee River at Garden Prairie Road at Garden Prairie, Ill.

$c, m$

Coon Creek at Riley, III.

05438201

05438250

$\mathrm{c}, \mathrm{m}$

$\mathrm{c}, \mathrm{m}$

Kishwaukee River above South Branch near Perryville, IIl.

05438600

05439000

$\mathrm{c}, \mathrm{m} \quad 05439500$

05440000

$\mathrm{c}, \mathrm{m}$

Kishwaukee River near Perryville, Ill.

Killbuck Creek near New Milford, Ill.

$\mathrm{c}, \mathrm{m}$

05440520

1978-90

Rock River Main Stem

Rock River at Byron, Ill.

Rock River at Oregon, III.

$\mathrm{c}, \mathrm{m}$

$\mathrm{t}$

Kyte River Basin

Kyte River at Daysville, Ill.

$$
\mathrm{c}, \mathrm{m}
$$

05442020

179

$1979-90$

Rock River Main Stem

Rock River at Grand Detour, III.

Rock River at Como, III.

Elkhorn Creek near Penrose, III.

Rock Creek near Erie, Ill.

$\begin{array}{llll}\mathrm{c}, \mathrm{m} & 05442200 & 8,502 & 1978-88 \\ \mathrm{c}, \mathrm{m} & 05443500 & 8,755 & 1906-07 \\ & & & 1978-91\end{array}$

\section{Elkhorn Creek Basin}

$c, m$

05444000

146

1979-91

\section{Rock Creek Basin}

05446100 
Table 4. Discontinued surface-water-quality and sediment stations operated by the Illinois District for which data were published-Continued

\begin{tabular}{l}
\hline Station nat \\
\hline Rock River near Joslin, Ill. \\
Green River near Deer Grove, Ill. \\
Green River near Geneseo, Ill.
\end{tabular}

Edwards River near New Boston, Ill.

Henderson Creek near Oquawka, Ill.

Bear Creek near Marcelline, Ill.

Bay Creek at Nebo, Ill.

Kankakee River at Momence, Ill.

Iroquois River at Iroquois, Ill.

Sugar Creek at Milford, III.

Iroquois River near Chebanse, Ill.

Kankakee River near Wilmington, Ill.

Des Plaines River at Russell, Ill.

Des Plaines River near Gurnee, Ill.

Des Plaines River near Des Plaines, Ill.

Des Plaines River near Schiller Park, Ill.

Salt Creek at Western Springs, Ill.

Addison Creek at Bellwood, Ill.

Des Plaines River at Riverside, Ill.

Des Plaines River at Romeoville, Ill.

Des Plaines River at Lockport, Ill.

North Branch Chicago River at Deerfield, Ill.

North Branch Chicago River at Niles, III.

\section{Rock River Main Stem}

$\mathrm{sc}, \mathrm{t}$

s

05446500

9,549

1980-82

\section{Green River Basin}

$\begin{array}{crrr}\mathrm{c}, \mathrm{m} & 05447100 & 322 & 1978-90 \\ \mathrm{c}, \mathrm{m} & 05447500 & 1,003 & 1978-91 \\ \mathrm{~S} & & & 1978-81\end{array}$

Edwards River Basin

$$
\mathrm{c}, \mathrm{m}
$$

05466500

445

1978-91

$\mathrm{s}$

\section{Henderson Creek Basin}

$$
\mathrm{c}, \mathrm{m}
$$

s

05469000

432

1978-91

1978-81

\section{Bear Creek Basin}

c

05495500

349

1978-91

Bay Creek Basin

$\mathrm{c}, \mathrm{m}$

05513000

161

$1978-90$

\section{ILLINOIS RIVER BASIN}

Kankakee River Basin

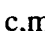

$\mathrm{c}, \mathrm{m}$

$\mathrm{s}$

$\mathrm{c}, \mathrm{m}$

$\mathbf{s}$

$\mathrm{c}, \mathrm{m}$

$\mathrm{c}, \mathrm{m}$

$\mathbf{s}$

$\mathrm{c}, \mathrm{m}$

$\mathrm{t}$

s

Des Plaines River Basin

c,m

c

$\mathrm{c}, \mathrm{m}$

$\mathrm{c}, \mathrm{m}$

$\mathrm{c}, \mathrm{m}$

$\mathrm{c}, \mathrm{m}$

$\mathrm{s}$

c

t

$c, m$

$\mathrm{c}, \mathrm{m}$

$\mathrm{c}, \mathrm{m}$

$\mathbf{s}$
05520500

05525000

05525500

05526000

05527500

05527800

05528000

05529000

05530590

05531500

05532000

05532500

05534000

05534050

05534500

05536000
2,294

1975-91

1975-77

1979-81

686

1978-91

1979-80

1978-91

1978-91

1979-81

1973-91

1973-77

1979-82

1978-91

1977-91

1978-91

1978-90

1978-91

1979-91

1979-82

1987-92

1974-77

1978-90

1978-91

1978-91

1985-86 
Table 4. Discontinued surface-water-quality and sediment stations operated by the Illinois District for which data were published-Continued

Station name
Des Pla
Chicago Sanitary and Ship Canal at Ashland Ave. at Chic
Little Calumet River at Munster, Ind.
Thorn Creek at Thornton, Ill.
Calumet Sag Channel at Blue Island, Ill.
Calumet Sag Channel at Sag Bridge, Ill.
Chicago Sanitary and Ship Canal at Romeoville, Ill.
Chicago Sanitary and Ship Canal at Lockport, Ill.
Des Plaines River at Route 53 at Joliet, Ill.
Des Plaines River at Rockdale, Ill.
Hickory Creek at Joliet, Ill.
Des Plaines River at Channahon, Ill.
West Branch Du Page River near West Chicago, Ill.
West Branch Du Page River near Warrenville, Ill.
East Branch Du Page River at Route 34 at Lisle, Ill.
Du Page River near Naperville, Ill.
Du Page River at Shorewood, Ill.

Du Page River at Shorewood, Ill.

Illinois River at Dresden Island, Ill.

Aux Sable Creek near Morris, Ill.

Mazon River near Coal City, Ill.

Illinois River at Marseilles, Ill.

Fox River near Channel Lake, Ill.

Nippersink Creek near Spring Grove, Ill.

Fox River at Burtons Bridge, Ill.

Fox River at Algonquin, Ill.

Poplar Creek at Elgin, Ill.

Fox River at South Elgin, Ill.

Fox River at Montgomery, Ill.

Blackberry Creek near Yorkville, Ill.

Somonauk Creek at Sheridan, Ill.

Fox River at Dayton, Ill.

Illinois River at Starved Rock, Ill.

\section{Du Page River Basin}

$\mathrm{c}, \mathrm{m}$
$\mathrm{c}$
$\mathrm{c}, \mathrm{m}$
$\mathrm{c}, \mathrm{m}$
$\mathrm{c}, \mathrm{m}$

05539900

05540095

05540210

05540290

05540500

05536135

05536195

05536275

05536368

05536700

05536995

05537000

05537980

05538010

05539000

05539670

Drainage

area

$\left(\mathrm{mi}^{2}\right)$

Period

of

record

$c, m$

$\mathrm{c}, \mathrm{m}$

t

Illinois River Main Stem

05541500

7,278

1967-77

Aux Sable Creek Basin

$c, m$

05541710

1979-87

Mazon River Basin

$\mathrm{c}, \mathrm{m}$

05542000

455

1978-91

Illinois River Main Stem

sc, $t$

05543500

8,259

1973-81

Fox River Basin

$\begin{array}{cc}\text { c,m } & 05546700 \\ \text { c,m } & 05548280 \\ \text { c,m } & 05549600 \\ \text { c,m } & 05550000 \\ \text { c } & 05550500 \\ \text { c,m } & 05551000 \\ \text { c,m } & 05551540 \\ \text { c,m } & 05551700 \\ \text { c,m } & 05551995 \\ \text { c } & 05552500\end{array}$

871

192

1976-91

1976-91

1,278

1,403

1979-87

1978-91

$35.2 \quad 1977-91$

$1,556 \quad 1978-91$

$1,732 \quad 1978-90$

$70.2 \quad 1978-91$

$83.3 \quad 1979-87$

2,642 1978-92

Illinois River Main Stem

$\mathrm{t}$

05553700

11,056

1967-77 
Table 4. Discontinued surface-water-quality and sediment stations operated by the Illinois District for which data were published-Continued

\begin{tabular}{l} 
Station name \\
\hline Vermilion River at McDowell, Ill. \\
Vermilion River near Leonore, Ill. \\
Little Vermilion River at La Salle, Ill. \\
Illinois River at Hennepin, Ill. \\
Big Bureau Creek at Princeton, Ill. \\
West Bureau Creek at Wyanet, Ill. \\
Illinois River at Henry, Ill. \\
Illinois River at Lacon, Ill. \\
Illinois River at Water Company at Peoria, Ill.
\end{tabular}

Vermilion River Basin

\begin{tabular}{cccc}
$\begin{array}{c}\text { Type of } \\
\text { data }\end{array}$ & $\begin{array}{c}\text { Station } \\
\text { number }\end{array}$ & $\begin{array}{c}\text { Drainage } \\
\text { area } \\
\left(\mathbf{m i}^{2}\right)\end{array}$ & $\begin{array}{c}\text { Period } \\
\text { of } \\
\text { record }\end{array}$ \\
\hline
\end{tabular}

$\begin{array}{crrr}\mathrm{c}, \mathrm{m} & 05554490 & 551 & 1978-91 \\ \mathrm{c}, \mathrm{m} & 05555300 & 1,251 & 1978-91 \\ \mathrm{~s} & & & 1980-81 \\ \mathrm{c}, \mathrm{m} & 05555950 & 125 & 1979-87\end{array}$

Illinois River Main Stem

Big Bureau Creek Basin

$\begin{array}{cccc}\text { c,m } & 05556500 & 196 & 1978-91 \\ \text { c,m } & 05557000 & 86.7 & 1979-91\end{array}$

Illinois River Main Stem

Illinois River at Lacon, Ill.

$\begin{array}{cll}\mathrm{s} & 05558300 & 13,543 \\ \mathrm{c}, \mathrm{m} & 05558995 & 12,953 \\ \mathrm{c}, \mathrm{m} & 05559900 & 13,900\end{array}$

1983-86

1978-91

1970-72,

1978-91

Farm Creek Basin

Farm Creek at Camp Street Bridge at East Peoria, Ill.

$\mathrm{c}, \mathrm{m}$

05562010

61.3

1979-87

Kickapoo Creek Basin

Kickapoo Creek at Bartonville, Ill.

$\mathrm{c}, \mathrm{m}$

05563525

304

1979-87

Illinois River at Lock and Dam at Peoria, Ill.

Illinois River at Pekin, Ill.

Illinois River Main Stem

$\begin{array}{clll}\mathrm{t} & 05563600 & 14,550 & 1974-77 \\ \mathrm{c}, \mathrm{m} & 05563800 & 14,585 & 1978-91\end{array}$

Mackinaw River below Congerville, Ill.

Mackinaw River Basin

c,m

05567510

776

1978-91

$\mathrm{s}$

$\mathrm{c}, \mathrm{m}$

05568005

1,092

1978-91

Illinois River Main Stem

Illinois River at Kingston Mines, Ill.

$t$

05568500

15,818

1975-77

Spoon River near Wyoming, Ill.

Indian Creek near Wyoming, Ill.

Spoon River Basin

$\begin{array}{cccl}\text { c,m } & 05568775 & 197 & 1979-87 \\ \text { c } & 05568800 & 62.7 & 1978-91 \\ \text { sc,t,s } & & & 1981 \\ \text { c,m } & 05568915 & 762 & 1979-87 \\ \text { c } & 05569500 & 1,062 & 1978-91 \\ \text { s } & 05570000 & 1,636 & 1981 \\ \text { c } & 05570350 & 28.0 & 1975-86 \\ \text { sc,t } & & & 1972-83 \\ \text { s } & & & 1972-80\end{array}$

Spoon River near Dahinda, Ill.

Spoon River at London Mills, Ill.

Spoon River at Seville, Ill.

Big Creek at St. David, Ill. 
Table 4. Discontinued surface-water-quality and sediment stations operated by the Illinois District for which data were published-Continued

\begin{tabular}{|c|c|c|c|c|}
\hline Station name & $\begin{array}{c}\text { Type of } \\
\text { data }\end{array}$ & $\begin{array}{l}\text { Station } \\
\text { number }\end{array}$ & $\begin{array}{c}\text { Drainage } \\
\text { area } \\
\left(\mathbf{m i}^{\mathbf{2}}\right)\end{array}$ & $\begin{array}{c}\text { Period } \\
\text { of } \\
\text { record }\end{array}$ \\
\hline \multicolumn{5}{|c|}{ Spoon River Basin-Continued } \\
\hline Evelyn Branch near Bryant, Ill. & $\begin{array}{c}\mathrm{sc}, \mathrm{t} \\
\mathrm{c}\end{array}$ & 05570360 & 5.78 & $\begin{array}{l}1972-80 \\
1972-92\end{array}$ \\
\hline \multirow[t]{2}{*}{ Big Creek near Bryant, Ill. } & $\mathrm{sc}, \mathrm{t}$ & 05570370 & 41.2 & $\begin{array}{l}1972-83 \\
1972-87\end{array}$ \\
\hline & $\mathrm{c}$ & & & $1972-92$ \\
\hline \multirow[t]{3}{*}{ Slug Run near Bryant, Ill. } & $\mathrm{sc}, \mathrm{t}$ & 05570380 & 7.12 & $1975-80$ \\
\hline & $\mathbf{s}$ & & & $1976-80$ \\
\hline & c & & & $1975-92$ \\
\hline \multicolumn{5}{|c|}{ Illinois River Main Stem } \\
\hline Illinois River at Power Company at Havana, Ill. & c & 05570520 & 18,300 & $1978-91$ \\
\hline \multicolumn{5}{|c|}{ Sangamon River Basin } \\
\hline Sangamon River at Fisher, Ill. & $\mathrm{c}, \mathrm{m}$ & 05570910 & 240 & $1979-91$ \\
\hline Sangamon River at Mahomet, Ill. & $\mathrm{c}, \mathrm{m}$ & 05571000 & 362 & 1978 \\
\hline Sangamon River at Monticello, Ill. & c & 05572000 & 550 & $1989-92$ \\
\hline Sangamon River at Allerton Park near Monticello, Ill. & $\mathrm{c}, \mathrm{m}$ & 05572125 & 573 & $1979-91$ \\
\hline Sangamon River at Lake Decatur Water Intake at Decatur, Ill. & $\mathrm{c}, \mathrm{m}$ & 05573504 & 927 & $1980-87$ \\
\hline Sangamon River at Route 48 at Decatur, Ill. & $\mathrm{c}, \mathrm{m}$ & 05573540 & 938 & $1979-91$ \\
\hline Sangamon River near Niantic, Ill. & $c, m$ & 05573650 & 1,054 & $1978-90$ \\
\hline Sangamon River at Roby, Ill. & $\mathrm{c}, \mathrm{m}$ & 05573800 & 1,264 & $1978-90$ \\
\hline Flat Branch near Taylorville, Ill. & $\mathrm{c}, \mathrm{m}$ & 05574500 & 276 & $1979-90$ \\
\hline South Fork Sangamon River at Kincaid, Ill. & $\mathrm{c}, \mathrm{m}$ & 05575500 & 562 & $1978-91$ \\
\hline Sangchris Lake near New City, Ill. & $\mathrm{c}, \mathrm{m}$ & 05575570 & -- & $1980-87$ \\
\hline South Fork Sangamon River below Rochester, Ill. & $\mathrm{c}, \mathrm{m}$ & 05576022 & 867 & $1978-91$ \\
\hline Sugar Creek near Springfield, Ill. & $\mathrm{c}, \mathrm{m}$ & 05576250 & 270 & $1979-87$ \\
\hline Sangamon River at Riverton, Ill. & $\mathrm{c}, \mathrm{m}$ & 05576500 & 2,618 & $1978-91$ \\
\hline Spring Creek at Burns Lane Bridge at Springfield, Ill. & $\mathrm{c}$ & 05577505 & 109 & $1979-91$ \\
\hline Sangamon River at Petersburg, Ill. & $\mathrm{c}, \mathrm{m}$ & 05578000 & 3,063 & $1978-90$ \\
\hline Salt Creek near Rowell, Ill. & $\mathrm{c}, \mathrm{m}$ & 05578500 & 335 & $1978-91$ \\
\hline Lake Fork near Cornland, Ill. & $\mathrm{c}, \mathrm{m}$ & 05579500 & 214 & $1978-91$ \\
\hline Kickapoo Creek at Waynesville, Ill. & $\mathrm{c}, \mathrm{m}$ & 05580000 & 227 & $1978-91$ \\
\hline Kickapoo Creek near Lincoln, Ill. & $\mathrm{c}, \mathrm{m}$ & 05580500 & 306 & $1978-91$ \\
\hline Sugar Creek near Hartsburg, Ill. & $\mathrm{c}, \mathrm{m}$ & 05581500 & 333 & $1978-91$ \\
\hline Salt Creek near Greenview, Ill. & $\mathrm{c}$ & 05582000 & 1,804 & $1978-91$ \\
\hline \multirow[t]{3}{*}{ Sangamon River near Oakford, Ill. } & $\mathbf{t}$ & 05583000 & 5,093 & $1976-77$ \\
\hline & $\mathrm{sc}, \mathrm{t}$ & & & $1979-81$ \\
\hline & $\mathbf{s}$ & & & 1981 \\
\hline Sugar Creek near Frederick, Ill. & $\mathrm{c}, \mathrm{m}$ & 05583915 & 162 & $1979-87$ \\
\hline \multicolumn{5}{|c|}{ La Moine River Basin } \\
\hline La Moine River at Colmar, Ill. & $\mathrm{c}, \mathrm{m}$ & 05584500 & 655 & $1975-91$ \\
\hline \multirow[t]{3}{*}{ La Moine River at Ripley, Ill. } & $\mathrm{c}, \mathrm{m}$ & 05585000 & 1,293 & $1975-91$ \\
\hline & $\mathrm{sc}, \mathrm{t}$ & & & 1979 \\
\hline & $\mathbf{s}$ & & & 1981 \\
\hline \multicolumn{5}{|c|}{ Illinois River Main Stem } \\
\hline Illinois River at Lock and Dam at La Grange, Ill. & $\mathrm{t}$ & 05585100 & 25,648 & $1968-77$ \\
\hline
\end{tabular}


Table 4. Discontinued surface-water-quality and sediment stations operated by the Illinois District for which data were published-Continued

\begin{tabular}{|c|c|c|c|c|}
\hline Station name & $\begin{array}{c}\text { Type of } \\
\text { data }\end{array}$ & $\begin{array}{l}\text { Station } \\
\text { number }\end{array}$ & $\begin{array}{c}\text { Drainage } \\
\text { area } \\
\left(\mathbf{m i}^{2}\right)\end{array}$ & $\begin{array}{c}\text { Period } \\
\text { of } \\
\text { record }\end{array}$ \\
\hline \multicolumn{5}{|c|}{ Indian Creek Basin } \\
\hline Indian Creek at Arenzville, Ill. & $\mathrm{c}, \mathrm{m}$ & 05585275 & 164 & $1978-90$ \\
\hline \multicolumn{5}{|c|}{ McKee Creek Basin } \\
\hline McKee Creek at Chambersburg, Ill. & $\mathrm{c}, \mathrm{m}$ & 05585830 & 341 & $1979-87$ \\
\hline \multicolumn{5}{|c|}{ Mauvaise Terre Creek Basin } \\
\hline Mauvaise Terre Creek near Merritt, Ill. & $\mathrm{c}, \mathrm{m}$ & 05586040 & 146 & $1978-90$ \\
\hline \multicolumn{5}{|c|}{ Illinois River Main Stem } \\
\hline Illinois River at Valley City, Ill. & $\mathrm{sc}, \mathrm{t}$ & 05586100 & 26,742 & $1975-81$ \\
\hline \multicolumn{5}{|c|}{ Apple Creek Basin } \\
\hline Apple Creek near Eldred, III. & $\mathrm{c}, \mathrm{m}$ & 05586600 & 404 & $1978-87$ \\
\hline \multicolumn{5}{|c|}{ Macoupin Creek Basin } \\
\hline Macoupin Creek near Macoupin, Ill. & $\mathrm{c}, \mathrm{m}$ & 05586690 & 304 & $1979-90$ \\
\hline Macoupin Creek near Kane, Ill. & $\mathrm{c}$ & 05587000 & 868 & $1978-91$ \\
\hline \multicolumn{5}{|c|}{ Illinois River Main Stem } \\
\hline Hllinois River at Hardin, Ill. & $\begin{array}{l}\mathrm{c} \\
\mathrm{t}\end{array}$ & 05587060 & 28,690 & $\begin{array}{r}1973-91 \\
1973-77\end{array}$ \\
\hline
\end{tabular}

\section{UPPER MISSISSIPPI RIVER BASIN BELOW THE ILLINOIS RIVER} Wood River Basin

Wood River at East Alton, Ill.

$\mathrm{c}, \mathrm{m} \quad 05587700$

Cahokia Creek at Edwardsville, Ill.

Cahokia Canal near Collinsville, Ill.

Canteen Creek near Collinsville, IIl.

Harding Ditch at East St. Louis, Ill.

Kaskaskia River near Pesotum, III. Kaskaskia River near Tuscola, Ill. Kaskaskia River at Cooks Mills, Ill. Kaskaskia River at Allenville, Ill. Jonathan Creek near Sullivan, Ill. Asa Creek at Sullivan, III.

West Okaw River near Lovington, Ill.

Kaskaskia River at Shelbyville, Ill.

Kaskaskia River near Cowden, Ill. Beck Creek at Herrick, Ill.

Kaskaskia River at Vandalia, Ill.

Hickory Creek near Bluff City, Ill.

Hurricane Creek near Mulberry Grove, Ill.

East Fork Kaskaskia River near Sandoval, Ill.

North Fork Kaskaskia River near Patoka, Ill.

\section{Cahokia Canal Basin}

$\begin{array}{cl}c & 05587900 \\ c, m & 05589490 \\ c, m & 05589510\end{array}$

212

1978-91

$$
\mathrm{c}, \mathrm{m}
$$

\section{Prairie Du Pont Creek Basin}

$$
\mathrm{c}, \mathrm{m}
$$

05589785

$-$

1978-87

\section{Kaskaskia River Basin}

$\begin{array}{ll}\text { c,m } & 05590400 \\ \text { c,m } & 05590420 \\ \text { c,m } & 05591200 \\ \text { c,m } & 05591300 \\ \text { c,m } & 05591400 \\ \text { c,m } & 05591500 \\ \text { c,m } & 05591700 \\ \text { c,m } & 05592000 \\ & \\ \text { c,m } & 05592100 \\ \text { c,m } & 05592195 \\ \text { c,m } & 05592500 \\ \text { c,m } & 05592600 \\ \text { c,m } & 05592800 \\ \text { c,m } & 05592900 \\ \text { c,m } & 05592930\end{array}$

1978-87

1978-87
1978-79

1979-87

1977-91

1980-87

1980-87

1978-90

1980-91

1906-07,

1978-91

$\begin{array}{cc}1,330 & 1978-91 \\ 97.0 & 1979-88\end{array}$

$1,940 \quad 1978-91$

$77.6 \quad 1978-88$

$152 \quad 1978-91$

$113 \quad 1978-91$

$39.1 \quad 1978-87$ 
Table 4. Discontinued surface-water-quality and sediment stations operated by the Illinois District for which data were published-Continued

\begin{tabular}{|c|c|c|c|c|}
\hline Station name & $\begin{array}{c}\text { Type of } \\
\text { data }\end{array}$ & $\begin{array}{l}\text { Station } \\
\text { number }\end{array}$ & $\begin{array}{c}\text { Drainage } \\
\text { area } \\
\left(\mathbf{m i}^{2}\right)\end{array}$ & $\begin{array}{l}\text { Period } \\
\text { of } \\
\text { record }\end{array}$ \\
\hline \multicolumn{5}{|c|}{ Kaskaskia River Basin-Continued } \\
\hline Kaskaskia River below Carlyle, III. & $\mathrm{c}, \mathrm{m}$ & 05593010 & 2,734 & $1978-91$ \\
\hline Crooked Creek near Odin, Ill. & $\mathrm{c}, \mathrm{m}$ & 05593505 & 89.2 & $1978-88$ \\
\hline Crooked Creek near Hoffman, III. & $\mathrm{c}$ & 05593520 & 254 & $1979-91$ \\
\hline Shoal Creek near Walshville, Ill. & $\mathrm{c}, \mathrm{m}$ & 05593785 & 281 & $1982-90$ \\
\hline Shoal Creek near Panama, Ill. & $\mathbf{c}, \mathbf{m}$ & 05593800 & 286 & $1978-82$ \\
\hline Shoal Creek near Breese, Ill. & c & 05594000 & 735 & $1979-91$ \\
\hline Sugar Creek at Albers, Ill. & $\mathrm{c}, \mathrm{m}$ & 05594090 & 124 & $1978-90$ \\
\hline Kaskaskia River near Venedy Station, Ill. & $\mathrm{c}, \mathrm{b}, \mathrm{m}$ & 05594100 & 4,393 & $1975-91$ \\
\hline & $\mathrm{sc}, \mathrm{t}$ & & & $1975-81$ \\
\hline Silver Creek near Troy, Ill. & $\mathrm{c}, \mathrm{m}$ & 05594450 & 154 & $1978-91$ \\
\hline Silver Creek near Freeburg, Ill. & $\mathrm{c}, \mathrm{m}$ & 05594800 & 464 & $1978-91$ \\
\hline Richland Creek near Hecker, Ill. & $\mathrm{c}, \mathrm{m}$ & 05595200 & 129 & $1978-91$ \\
\hline Plum Creek near Baldwin, Ill. & $\mathrm{c}, \mathrm{m}$ & 05595280 & 60.9 & $1979-87$ \\
\hline Kaskaskia River at Roots, Ill. & $\mathrm{c}, \mathrm{m}$ & 05595400 & 5,790 & $1978-87$ \\
\hline \multicolumn{5}{|c|}{ Marys River Basin } \\
\hline Marys River at Welge, Ill. & $\mathrm{c}, \mathrm{m}$ & 05595540 & 113 & $1978-90$ \\
\hline \multicolumn{5}{|c|}{ Big Muddy River Basin } \\
\hline Big Muddy River near Mt. Vernon, Ill. & $\mathrm{c}, \mathrm{m}$ & 05595700 & 71.9 & $1978-90$ \\
\hline Rayse Creek near Waltonville, Ill. & $\mathrm{c}, \mathrm{m}$ & 05595730 & 88.0 & $1978-91$ \\
\hline Casey Fork at Route 37 near Mt. Vernon, Ill. & $\mathrm{c}, \mathrm{m}$ & 05595830 & 87.7 & $1978-91$ \\
\hline Rend Lake near Benton, Ill. & $\mathrm{c}, \mathrm{m}$ & 05595950 & 488 & $1979-87$ \\
\hline Middle Fork Big Muddy River near Benton, Ill. & $\mathrm{c}, \mathrm{m}$ & 05596400 & 152 & $1978-87$ \\
\hline Big Muddy River at Plumfield, Ill. & $\mathrm{c}, \mathrm{m}$ & 05597000 & 794 & 1978-91 \\
\hline Pond Creek at West Frankfort, Ill. & $\mathrm{c}, \mathrm{m}$ & 05597040 & 33.1 & $1978-88$ \\
\hline Little Muddy River near Elkville, Ill. & $\mathrm{c}, \mathrm{m}$ & 05597280 & 213 & $1978-88$ \\
\hline Crab Orchard Creek near Marion, IIl. & $\mathrm{c}, \mathrm{m}$ & 05597500 & 31.7 & $1978-91$ \\
\hline $\begin{array}{l}\text { Crab Orchard Creek below Crab Orchard Lake } \\
\text { near Carterville, Ill. }\end{array}$ & $\mathrm{c}, \mathrm{m}$ & 05598050 & 201 & $1978-90$ \\
\hline Crab Orchard Creek near Carbondaie, Ill. & $\mathrm{c}, \mathrm{m}$ & 05598245 & 272 & $1978-88$ \\
\hline White Walnut Creek near Pinckneyville, Ill. & $\mathrm{c}, \mathrm{sc}, \mathrm{t}$ & 05598480 & 16.5 & $1980-81$ \\
\hline Beaucoup Creek near Vergennes, Ill. & $\mathrm{c}, \mathrm{m}$ & 05599200 & 478 & $1978-88$ \\
\hline Big Muddy River at Murphysboro, Ill. & $\mathrm{sc}, \mathrm{t}$ & 05599500 & 2,169 & $1975-81$ \\
\hline & c & & & $1975-92$ \\
\hline Kinkaid Creek near Murphysboro, Ill. & $\mathrm{c}, \mathrm{m}$ & 05599540 & 60.2 & $1980-87$ \\
\hline Cedar Creek near Pomona, Ill. & $\mathrm{c}, \mathrm{m}$ & 05599565 & 34.5 & $1980-87$ \\
\hline \multicolumn{5}{|c|}{ Cache River Basin } \\
\hline Cache River at Sandusky, Ill. & $\mathrm{c}, \mathrm{m}$ & 05600150 & 234 & 1978-87 \\
\hline \multicolumn{5}{|c|}{ Mississippi River Main Stem } \\
\hline Mississippi River at Kellogg, Ill. & $\mathbf{t}$ & 07020125 & 706,300 & 1974-77 \\
\hline
\end{tabular}


Table 5. Ground-water stations in Illinois, by county, for which data are published by the Illinois District [L, Ground-water level measurement; Q, Ground-water quality determination]

\begin{tabular}{|c|c|c|c|}
\hline $\begin{array}{c}\text { Station } \\
\text { number }\end{array}$ & Local well name & Ownership & $\begin{array}{c}\text { Type of } \\
\text { data }\end{array}$ \\
\hline \multicolumn{4}{|c|}{ ADAMS COUNTY } \\
\hline \multicolumn{4}{|c|}{ BOONE COUNTY } \\
\hline 421649088513801 & Belvidere Well No. 9 & Municipal & Q \\
\hline \multicolumn{4}{|c|}{ BUREAU COUNTY } \\
\hline 412220089280301 & $16 \mathrm{~N} 9 \mathrm{E}-16.8 \mathrm{e} 1$ & Private & $\mathrm{L}$ \\
\hline 412232089275101 & Princeton Well No. 5 & Municipal & $\mathrm{Q}$ \\
\hline 412242089125101 & Ladd Well No. 1 & Municipal & $\mathrm{Q}$ \\
\hline 412325089293701 & $16 \mathrm{~N} 9 \mathrm{E}-7.2 \mathrm{~g} 1$ & Municipal & $\mathrm{L}$ \\
\hline \multicolumn{4}{|c|}{ CHAMPAIGN COUNTY } \\
\hline 400832088190601 & Champaign Well No. 54 & Private & Q \\
\hline 401841088094701 & Rantoul Well No. 7 & Municipal & Q \\
\hline \multicolumn{4}{|c|}{ CLARK COUNTY } \\
\hline 392822087594101 & Westfield Well No. 7 & Municipal & Q \\
\hline \multicolumn{4}{|c|}{ DE KALB COUNTY } \\
\hline 414608088375201 & $38 \mathrm{~N} 5 \mathrm{E}-14.4 \mathrm{~d} 1$ & Municipal & $\mathrm{L}$ \\
\hline 415424088462501 & De Kalb Well No. 12 & Municipal & $\mathrm{Q}$ \\
\hline \multicolumn{4}{|c|}{ DE WITT COUNTY } \\
\hline 400647088481101 & Weldon Well No. 5 & Municipal & Q \\
\hline \multicolumn{4}{|c|}{ DU PAGE COUNTY } \\
\hline 414217087592801 & $37 \mathrm{~N} 11 \mathrm{E}-9.8 \mathrm{c} 1$ & Federal & $\mathrm{L}, \mathrm{Q}$ \\
\hline \multicolumn{4}{|c|}{ FAYETTE COUNTY } \\
\hline 390759089073102 & Ramsey Well No. 6 & Municipal & $\mathrm{Q}$ \\
\hline \multicolumn{4}{|c|}{ GRUNDY COUNTY } \\
\hline 411112088180601 & Gardner Well No. 2 & Municipal & Q \\
\hline 412129088252701 & Morris Well No. 4 & Municipal & Q \\
\hline 412720088153201 & $34 \mathrm{~N} 8 \mathrm{E}-1.3 \mathrm{el}$ & Municipal & $\mathrm{L}$ \\
\hline \multicolumn{4}{|c|}{ HANCOCK COUNTY } \\
\hline 401407091034101 & Bowen Well No. 2 & Municipal & Q \\
\hline \multicolumn{4}{|c|}{ HENDERSON COUNTY } \\
\hline 405512090573601 & Galesburg Well No. 74-3 & Municipal & Q \\
\hline \multicolumn{4}{|c|}{ HENRY COUNTY } \\
\hline 412832090082901 & Geneseo Well No. 25 & Municipal & Q \\
\hline \multicolumn{4}{|c|}{ IROQUOIS COUNTY } \\
\hline 404629087453801 & Watseka Well No. 7 & Municipal & $\mathrm{Q}$ \\
\hline
\end{tabular}


Table 5. Ground-water stations in Illinois, by county, for which data are published by the Illinois District-Continued

\begin{tabular}{|c|c|c|c|}
\hline $\begin{array}{l}\text { Station } \\
\text { number }\end{array}$ & Local well name & Ownership & $\begin{array}{c}\text { Type of } \\
\text { data }\end{array}$ \\
\hline \multicolumn{4}{|c|}{ KANE COUNTY } \\
\hline 414529088264301 & Sugar Grove Well No. 2 & Municipal & $\mathbf{Q}$ \\
\hline 415257088202001 & Geneva Well No. 6 & Municipal & $\mathbf{Q}$ \\
\hline 420507088325501 & $41 \mathrm{~N} 6 \mathrm{E}-9.1 \mathrm{lg} 2$ & Municipal & $\mathrm{L}$ \\
\hline 420720088154601 & Carpentersville Well No. 6 & Municipal & Q \\
\hline \multicolumn{4}{|c|}{ KANKAKEE COUNTY } \\
\hline 410127087425201 & St. Anne Well No. 3 & Municipal & Q \\
\hline 410325088022301 & Herscher Well No. 8 & Municipal & $\mathbf{Q}$ \\
\hline 411010087400901 & Momence Well No. 4 & Municipal & $\mathrm{Q}$ \\
\hline \multicolumn{4}{|c|}{ LAKE COUNTY } \\
\hline 421537088082101 & Wauconda Well No. 2 & Municipal & $\mathrm{Q}$ \\
\hline 422803087475301 & $46 \mathrm{~N} 12 \mathrm{E}-14.6 \mathrm{~g} 1$ & Federal & $\mathrm{L}, \mathrm{Q}$ \\
\hline 422803087475302 & $46 \mathrm{~N} 12 \mathrm{E}-14.6 \mathrm{~g} 2$ & Federal & $\mathrm{L}, \mathrm{Q}$ \\
\hline 422803087475303 & $46 \mathrm{~N} 12 \mathrm{E}-14.6 \mathrm{~g} 3$ & Federal & $\mathrm{L}, \mathrm{Q}$ \\
\hline 422803087475304 & $46 \mathrm{~N} 12 \mathrm{E}-14.6 \mathrm{~g} 4$ & Federal & $\mathrm{L}, \mathrm{Q}$ \\
\hline \multicolumn{4}{|c|}{ LA SALLE COUNTY } \\
\hline 412120088500401 & Ottawa Well No. 8 & Municipal & Q \\
\hline 413255089064801 & Mendota Well No. 3 & Municipal & $\mathrm{Q}$ \\
\hline \multicolumn{4}{|c|}{ MADISON COUNTY } \\
\hline 385117090063701 & Wood River Well No. 6 & Municipal & Q \\
\hline \multicolumn{4}{|c|}{ MASON COUNTY } \\
\hline 401754090032001 & Havana Well No. 5 & Municipal & Q \\
\hline 401811089361801 & San Jose Well No. 4 & Municipal & Q \\
\hline \multicolumn{4}{|c|}{ MASSAC COUNTY } \\
\hline 370843088435301 & Metropolis Well No. 2 & Municipal & Q \\
\hline \multicolumn{4}{|c|}{ MCHENRY COUNTY } \\
\hline 421034088164601 & Algonquin Well No. 1 & Municipal & Q \\
\hline 422525088361401 & Harvard Well No. 6 & Municipal & Q \\
\hline \multicolumn{4}{|c|}{ MONROE COUNTY } \\
\hline 381749090185301 & Valmeyer Well No. 4 & Municipal & Q \\
\hline \multicolumn{4}{|c|}{ OGLE COUNTY } \\
\hline 420453089172601 & $24 \mathrm{~N} 10 \mathrm{E}-13.6 \mathrm{e} 2$ & Federal & L \\
\hline 420717089241301 & Leaf River Well No. 2 & Municipal & $\mathrm{Q}$ \\
\hline \multicolumn{4}{|c|}{ PEORIA COUNTY } \\
\hline 404511090004001 & Elmwood Well No. 3 & Municipal & Q \\
\hline 405536089300401 & Chillicothe Well No. 7 & Municipal & $\mathrm{Q}$ \\
\hline \multicolumn{4}{|c|}{ PULASKI COUNTY } \\
\hline 371637089105401 & Ullin Well No. 1 & Municipal & Q \\
\hline 373617089120301 & Mounds Well No. 1 & Municipal & Q \\
\hline
\end{tabular}


Table 5. Ground-water stations in Illinois, by county, for which data are published by the Illinois District-Continued

\begin{tabular}{|c|c|c|c|}
\hline $\begin{array}{c}\text { Station } \\
\text { number }\end{array}$ & Local well name & Ownership & $\begin{array}{c}\text { Type of } \\
\text { data }\end{array}$ \\
\hline \multicolumn{4}{|c|}{ ROCK ISLAND COUNTY } \\
\hline 412555090265401 & Coal Valley Well No. 3 & Municipal & $\mathrm{Q}$ \\
\hline 412634090431201 & Andalusia Well No. 1 & Municipal & Q \\
\hline \multicolumn{4}{|c|}{ ST. CLAIR COUNTY } \\
\hline 383916090023501 & Mound PWD Well No. 1 & Municipal & Q \\
\hline \multicolumn{4}{|c|}{ STEPHENSON COUNTY } \\
\hline 421813089373901 & Freeport Well No. 4 & Municipal & Q \\
\hline \multicolumn{4}{|c|}{ TAZEWELL COUNTY } \\
\hline 404222089243201 & Washington Well No. 7 & Municipal & Q \\
\hline \multicolumn{4}{|c|}{ WAYNE COUNTY } \\
\hline 383036088255001 & Cisne Well No. 3 & Municipal & Q \\
\hline \multicolumn{4}{|c|}{ WHITE COUNTY } \\
\hline 380549088042101 & Carmi Well No. 3 & Municipal & Q \\
\hline \multicolumn{4}{|c|}{ WHITESIDE COUNTY } \\
\hline 413922090044101 & Erie Well No. 2 & Municipal & Q \\
\hline \multicolumn{4}{|c|}{$\begin{array}{l}\text { WILL COUNTY } \\
\end{array}$} \\
\hline 412518087590901 & Manhattan Well No. 2 & Municipal & Q \\
\hline 413238088084601 & Joliet Rooney Site & Municipal & Q \\
\hline 413514088011901 & Lockport Well No. 5 & Municipal & Q \\
\hline \multicolumn{4}{|c|}{ WINNEBAGO COUNTY } \\
\hline 422723089034001 & Rockton Well No. 5 & Municipal & $\mathrm{Q}$ \\
\hline 422929089020901 & South Beloit Well No. 3 & Municipal & $\mathrm{Q}$ \\
\hline 422930089023201 & $46 \mathrm{~N} 2 \mathrm{E}-6.2 \mathrm{dl}$ & Private & $\mathrm{L}, \mathrm{Q}$ \\
\hline
\end{tabular}

